\title{
Feeding habits and novel prey of larval fishes in the northern San Francisco Estuary
}

Running Title: Estuarine diets of larval fishes

Authors: Michelle J. Jungbluth ${ }^{{ }^{*}}$, Jillian Burns ${ }^{1,2}$, Lenny Grimaldo ${ }^{3,4}$, Anne Slaughter ${ }^{1}$, Aspen

Katla $^{5}$, Wim Kimmerer ${ }^{1}$

Affiliations:

${ }^{1}$ Estuary and Ocean Science Center, San Francisco State University, Tiburon, CA, ${ }^{2}$ California Department of Fish and Wildlife, Sacramento, CA (Current affiliation)

${ }^{3}$ ICF Inc., Richmond, CA

${ }^{4}$ California Department of Water Resources, Sacramento, CA (Current affiliation)

${ }^{5}$ North Seattle College, Seattle, WA

*Corresponding author: mjungbluth@sfsu.edu, Phone: 1(415) 435-7127

Keywords: metabarcoding, larval fish, diet, zooplankton, mtCOI, Pacific herring, longfin smelt

\section{Acknowledgements:}

Funding was provided by the Sea Grant Delta Science Fellowship program and the State and Federal Contractors Water Association grant \#18-02, an NSF-REU fellowship for A. Katla at San Francisco State University, grant P1696013 from the California Department of Fish and Wildlife to San Francisco State University. Larval fish trawls were collected under California Fish and Wildlife Prop 1 Grant study 2081; CESA Scientific Collecting Permit \#4086 to ICF Inc.

4 Funding for the San Francisco State University MiSeq sequencer was provided by NSF Award \#1427772. Fish diet sequencing was carried out at the DNA Technologies and Expression Analysis Cores at the UC Davis Genome Center, supported by NIH Shared Instrumentation Grant 1S10OD010786-01. We thank the UC Davis Fish Conservation and Culturing Laboratory facility for providing longfin smelt adults to aid in primer design, C. Brennan for expertise in fish taxonomy, M. Conrad for assistance with library preparation, and F. Feyrer for providing input along the development of the project. 


\section{$31 \quad$ Abstract}

32 Food limitation can dampen survival and growth of fish during early development. To

33 investigate prey diversity important to the planktivorous larval longfin smelt (Spirinchus

34 thaleichthys) and Pacific herring (Clupea pallasii) from the San Francisco Estuary, we used

35 DNA metabarcoding analysis of the cytochrome oxidase I gene on the guts of these fishes and on

36 environmental zooplankton samples. Differential abundance analysis suggested that both species

37 consumed the most abundant zooplankton at a lower rate than their availability in the

38 environment. Both fish consumed the prey that were commonly available and relatively

39 abundant. Prey taxa substantially overlapped between the two species (Schoener's index $=0.66$ ),

40 and alpha diversity analysis suggested high variability in the content of individual guts.

41 Abundant prey taxa in both fish species included the copepods Eurytemora carolleeae,

42 Acanthocyclops americanus, and A. robustus; the Acanthocyclops spp. are difficult to identify

43 morphologically. A few uncommon prey in the diets hint at variable feeding strategies, such as

44 herring (presumably egg) DNA in the longfin smelt diets, which suggests feeding near

45 substrates. Herring consumed the small $(<0.5 \mathrm{~mm})$ copepod Limnoithona tetraspina more

46 frequently $(30 \%)$ than did smelt (2\%), possibly indicating differences in foraging behavior or

47 sensory abilities. Among the unexpected prey found in the diets was the cnidarian Hydra

48 oligactis, the polychaete Dasybranchus sp., and a newly identified species Mesocyclops

49 pehpeiensis. "Unknown" DNA was in $56 \%$ of longfin smelt diets and $57 \%$ of herring diets, and

50 made up $17 \%$ and $21 \%$ of the relative read abundance in the two species, respectively. Our

51 results suggest that these two fishes, which overlap in nursery habitat, also largely overlap in

52 food resources necessary for larval survival.

54 Keywords: metabarcoding, larval fish, diet, zooplankton, mtCOI, herring, smelt 


\section{Introduction}

Estuaries provide critical nursery habitats for many coastal and anadromous species including forage fishes (Beck et al., 2001; Boehlert \& Mundy 1988), which are an important link between plankton and higher-level predators (Cury et al., 2000; Cury et al., 2011; Hunt et al., 2002). Knowledge of the prey that support recruitment of forage fishes in estuarine nursery habitats could improve management of these habitats. While some studies have investigated the diets of larval fishes in estuarine habitats, few have applied the high level of taxonomic resolution available through dietary DNA (dDNA) metabarcoding and, as a result, are likely to miss many potentially important or informative taxa. Larval fishes feed on small planktonic organisms that can be hard to identify visually, and some softer-bodied organisms may be limiting our knowledge of the breadth of prey important to fish recruitment (Llopiz 2013; Montagnes et al., 2010).

In the northern, brackish to fresh reaches of the San Francisco Estuary (SFE), key forage fish species of management interest have declined substantially over the last few decades (Sommer et al., 2007), including longfin smelt Spirinchus thaleichthys (state-listed as threatened), delta smelt (Hypomesus transpacificus; state and federally listed) and striped bass Morone saxatilis. A downward shift in overall prey abundance and a change in prey availability are both implicated as major factors responsible for the declining trend of forage fish in the low salinity zone of the SFE (Kimmerer 2002; Kimmerer 2006; Kimmerer \& Orsi 1996; Orsi \& Ohtsuka 1999; Sommer et al., 2007; Thompson et al., 2010; Rose et al., 2013). The reduction in prey abundance is mostly attributable to grazing effects caused by the non-native Asian clam Potamacorbula amurensis following its establishment in the estuary in the late 1980's. Prey availability in the low-salinity zone shifted from a zooplankton community numerically dominated by calanoid copepods to one dominated by a small cyclopoid copepod, Limnoithona tetraspina (Bouley \& Kimmerer 2006).

Growth and survival of larval fish in estuarine ecosystems is strongly linked to suitable prey availability and associated energetic costs of capturing prey while maintaining position in a tidal environment (Leggett \& Deblois 1994; Pepin 2004; Pepin et al., 2014). Thus, both declines in prey abundance and shifts in prey availability could affect the successful recruitment of forage fish larvae in the northern SFE. Diet shifts have been documented for juvenile and adult fish in 
87 the SFE that have undergone significant declines in abundance, including striped bass and 88 longfin smelt (Bryant \& Arnold 2007; Feyrer et al., 2003). In other cases, the decline in prey 89 abundance has caused some forage fish in the northern SFE to shift their distribution seaward

90 (Kimmerer 2006) or towards different habitats where foraging opportunities may be better 91 (Sommer et al., 2011).

92 The impact of the food web collapse in the northern SFE to larval life stages of forage 93 fish is less understood but may be important for understanding interannual variation in 94 recruitment. Here, we study the diet patterns of larval longfin smelt and Pacific herring. Longfin 95 smelt are small pelagic fish that use the lower salinity habitat in the SFE for spawning and larval 96 rearing, while sub-adults and adults are thought to rear primarily in the ocean or San Francisco 97 Bay. Both the distribution and abundance of longfin smelt varies strongly with freshwater flow.

98 During years of higher freshwater flow into the estuary, larval longfin smelt rearing shifts 99 seaward and into shallow marsh habitats (Grimaldo et al., 2017; 2020). Correspondingly, age-0

100 longfin smelt abundance is higher by almost two orders of magnitude during years with higher

101 freshwater flow compared to years when freshwater flow is low (Kimmerer et al., 2009). Rearing

102 conditions may be enhanced during high-flow years but mechanisms for effects of flow on

103 rearing conditions are still largely unknown (Grimaldo et al., 2020). Pacific herring spawn

104 adhesive eggs on substrates mainly in the seaward regions of the estuary but larvae can be

105 broadly distributed throughout the estuary depending on freshwater flow. For example, Grimaldo

106 et al., (2020) observed larval herring in relatively modest abundance in the northern estuary

107 during a low flow year which may be due either net landward movement via two-layer

108 gravitational flow or some local spawning activity.

109 Rearing of longfin smelt and Pacific herring larvae may overlap in the SFE in some years 110 (Grimaldo et al., 2020), thus we would expect them to have similar diets through foraging in a 111 shared prey field when their spatial distributions are similar. Studies of feeding by larval longfin 112 smelt to date are rare, but morphological gut content analyses of larvae have found copepods to 113 be important prey, including Acanthocyclops spp., Pseudodiaptomus forbesi (Hobbs et al., 114 2006), and Eurytemora carolleeae (formerly E. affinis; Alekseev \& Souissi 2011; Slater 2015). 115 Herring diet studies in Central San Francisco Bay (7-9 mm larvae) found tintinnid ciliates to be 116 the most common prey, followed by juvenile copepods, diatoms, gastropod veligers, and 117 unknown crustaceans (Bollens \& Sanders 2004). In other studies, larval Pacific herring 
118 consumed calanoid and harpacticoid copepods (Bowers \& Williamson 1951; Wailes 1936), 119 diatoms, rotifers (Choi et al., 2015), cirripede and gastropod larvae (Blaxter 1965; Bowers \& 120 Williamson 1951; Wailes 1936), fish eggs, and Artemia sp. (Blaxter 1965; Kurata 1959). To date 121 there has been no direct comparison of prey consumed by larval longfin smelt and Pacific 122 herring when their distributions overlap.

123 Morphological gut content analysis is the most direct method for analyzing feeding and 124 has been a mainstay of aquatic trophic studies for over a century (Evermann \& Lee 1906). Like 125 any single method, this type of analysis has several limitations: identification of prey depends on 126 the skill of the analyst, guts may contain unidentifiable material or appear empty but still contain 127 prey remains (e.g., Slater \& Baxter 2014), and variable digestion time of the prey can bias results 128 toward hard-bodied prey (Hyslop 1980). All of these limitations can lead to an incomplete 129 understanding of aquatic food webs (Pompanon et al., 2012; Sousa et al., 2019). Although 130 arthropods are important prey for larval fishes (Llopiz 2013), many soft-bodied plankton can 131 provide important nutrition to larval fishes. For example, protists may alleviate food limitation in 132 larval fish (Hunt von Herbing \& Gallager, 2000; Stoecker \& Capuzzo 1990) and may be 133 assimilated more easily than invertebrates (Reitan et al., 1998).

134 Application of DNA metabarcoding to investigate diets has successfully identified a wide 135 range of previously unknown prey in a wide variety of aquatic species (Pompanon et al., 2012;

136 Roslin \& Majaneva 2016; Sousa et al., 2019) including lobster larvae (O'Rorke et al., 2012), 137 copepods (Harfman et al., 2019; Ho et al., 2017), copepod nauplii (Craig et al., 2014), and fishes 138 (e.g., Albaina et al., 2016; Hirai et al., 2017; Leray et al., 2019; Waraniak et al, 2019). This is 139 possible because molecular techniques can detect and identify specific prey DNA in a predator's 140 digestive system down to a few copies of a gene, long after the prey's body has decomposed 141 beyond morphological recognition (Pompanon et al., 2012; Sousa et al., 2019). While no dDNA 142 studies have been done on the larvae of Pacific herring or longfin smelt to date, dDNA studies of 143 other clupeid larvae and juveniles revealed diverse prey including numerous species of 144 copepods, decapods, ostracods, cnidarians, as well as phyllodocid and capitellid polychaetes, 145 echinoderms, bivalves, gastropods and other fish species (Bowser et al., 2013; Hirai et al., 2017). 146 These results suggest that Pacific herring and longfin smelt likely consume more diverse prey 147 taxa than has been detected by morphological diet analysis. 
We identified the prey in larval longfin smelt and Pacific herring guts collected during the same time period in the SFE to determine diet similarity based on an ambient prey field. We applied metabarcoding analysis of the mitochondrial cytochrome oxidase subunit I (mtCOI) gene across diverse taxa to detect and identify common prey taxa in guts that may be missed by traditional morphological methods. Feeding specialization among habitats was inferred for the two species from the diet analysis.

\section{Materials and Methods}

156 Study Area and Sample Collection

The San Francisco Estuary, the largest estuary on the west coast of the United States, which drains about 40 percent of California's area. The climate is mediterranean with most of the freshwater runoff occurring in winter to early spring, and most flows through the

160 California Delta linking the Sacramento and San Joaquin rivers through Suisun, San Pablo, and

161 San Francisco Bays to the Pacific Ocean (Fig. 1). Other sources of freshwater in the estuary

162 include small streams and large tributaries (e.g., the Petaluma River). Fish and zooplankton were 163 collected for this study during the spring of 2017, which was the year of highest freshwater flow

164 from 1955 to 2020 (Grimaldo et al., 2020). During high flow years, distributions of pelagic

165 fishes such as longfin smelt and Pacific herring shift seaward, generally tracking the salinity 166 distribution (Grimaldo et al., 2020).

167 Larval fish and zooplankton were collected across different habitats in San Pablo Bay and 168 Suisun Bay of the northern SFE (Figure 1, Table 1). San Pablo Bay and Suisun Bay are shallow 169 brackish embayments connected by a narrow deep channel (Carquinez Strait). Sampling 170 occurred between 28 February 2017 and 25 May 252017 for a total of 32 samples. Sites were 171 identified based on habitat and location and selected for sampling based on a randomly stratified 172 sample design. The four habitat types sampled in both regions comprised shallow open water 173 shoals, channels of tidal marshes, and deep open channels near the water surface (channel 174 surface) and near the bottom (channel bottom).

175 Two nets were towed to collect larval fishes and zooplankton concurrently: a $0.52 \mathrm{~m}$ 176 diameter $505 \mu \mathrm{m}$ mesh net with a filtering cod end for larval fish and a $0.35 \mathrm{~m} 150 \mu \mathrm{m}$ mesh net 177 with a filtering cod end for zooplankton. Each net was fitted with a General Oceanics flowmeter 
178 Table 1 Sample information corresponding to tow numbers where zooplankton and fish samples 179 were collected.

\begin{tabular}{|c|c|c|c|c|c|c|c|}
\hline Date & Time & $\begin{array}{c}\text { Tow } \\
\#\end{array}$ & Latitude & Longitude & Region & Habitat & $\begin{array}{c}\text { Fish } \\
\text { Present }\end{array}$ \\
\hline $2 / 28 / 17$ & 09:22 & 1 & 38.0674 & -122.2900 & San Pablo & Shoal & - \\
\hline $2 / 28 / 17$ & 09:46 & 2 & 38.0574 & -122.2714 & San Pablo & Channel Surface & - \\
\hline $2 / 28 / 17$ & 10:11 & 3 & 38.0574 & -122.2714 & San Pablo & Channel Bottom & - \\
\hline $2 / 28 / 17$ & $11: 17$ & 4 & 38.0338 & -122.1105 & San Pablo & Shoal & - \\
\hline $2 / 28 / 17$ & $11: 52$ & 5 & 38.0327 & -122.1670 & San Pablo & Shoal & - \\
\hline $3 / 7 / 17$ & $08: 13$ & 6 & 38.0368 & -122.1044 & Suisun & Tidal Marsh & $\mathrm{F}$ \\
\hline $3 / 7 / 17$ & $08: 53$ & 7 & 38.0384 & -122.1039 & Suisun & Shoal & - \\
\hline $3 / 7 / 17$ & 09:46 & 8 & 38.0674 & -122.0068 & Suisun & Shoal & - \\
\hline $3 / 7 / 17$ & $10: 51$ & 9 & 38.0837 & -122.0171 & Suisun & Shoal & - \\
\hline $3 / 7 / 17$ & $11: 58$ & 10 & 38.0875 & -122.0838 & Suisun & Shoal & - \\
\hline $3 / 7 / 17$ & $12: 49$ & 11 & 38.0583 & -122.0391 & Suisun & Channel Surface & - \\
\hline $3 / 7 / 17$ & $13: 32$ & $12+$ & 38.0586 & -122.0389 & Suisun & Channel Bottom & - \\
\hline $3 / 9 / 17$ & 08:32 & $13+$ & 38.0576 & -122.2709 & San Pablo & Channel Bottom & $\mathrm{F}$ \\
\hline $3 / 9 / 17$ & $09: 54$ & 14 & 38.0572 & -122.2705 & San Pablo & Channel Bottom & $\mathrm{F}$ \\
\hline $3 / 9 / 17$ & $11: 34$ & $15+$ & 38.1170 & -122.4838 & San Pablo & Tidal Marsh & $\mathrm{F}$ \\
\hline $3 / 9 / 17$ & $12: 44$ & $16+$ & 38.1350 & -122.5181 & San Pablo & Channel Surface & $\mathrm{F}$ \\
\hline $3 / 9 / 17$ & $13: 37$ & 17 & 38.1552 & -122.5401 & San Pablo & Channel Surface & $\mathrm{F}$ \\
\hline $3 / 9 / 17$ & $14: 22$ & 18 & 38.1551 & -122.5399 & San Pablo & Channel Bottom & - \\
\hline $3 / 22 / 17$ & 08:51 & 19 & 38.0359 & -122.1071 & Suisun & Tidal Marsh & - \\
\hline $3 / 22 / 17$ & 09:30 & $20+$ & 38.0385 & -122.1058 & Suisun & Shoal & $\mathrm{F}$ \\
\hline $3 / 22 / 17$ & $10: 41$ & 21 & 38.0411 & -122.1056 & Suisun & Channel Bottom & $\mathrm{F}$ \\
\hline $3 / 22 / 17$ & 13:03 & 22 & 38.1015 & -122.0085 & Suisun & Shoal & $\mathrm{F}$ \\
\hline $3 / 23 / 17$ & $07: 26$ & $23+$ & 38.0591 & -122.2050 & Suisun & Shoal & $\mathrm{F}$ \\
\hline $3 / 23 / 17$ & 08:37 & 24 & 38.0598 & -122.2902 & San Pablo & Shoal & $\mathrm{F}$ \\
\hline $3 / 23 / 17$ & 09:37 & 25 & 38.1175 & -122.4835 & San Pablo & Tidal Marsh & $\mathrm{F}$ \\
\hline $3 / 23 / 17$ & 10:29 & $26+$ & 38.0550 & -122.4915 & San Pablo & Tidal Marsh & $\mathrm{F}$ \\
\hline $4 / 4 / 17$ & 09:10 & 27 & 38.0588 & -122.0381 & Suisun & Channel Bottom & - \\
\hline $4 / 4 / 17$ & 11:06 & 28 & 38.0748 & -122.0044 & Suisun & Tidal Marsh & - \\
\hline $4 / 4 / 17$ & $11: 58$ & $29+$ & 38.1092 & -121.9922 & Suisun & Shoal & - \\
\hline 4/18/17 & $15: 13$ & 35 & 38.0658 & -122.2065 & Suisun & Shoal & - \\
\hline $5 / 25 / 17$ & $11: 53$ & 39 & 38.0414 & -122.1091 & Suisun & Tidal Marsh & $\mathrm{F}$ \\
\hline $5 / 25 / 17$ & $12: 57$ & 40 & 38.0389 & -122.1126 & Suisun & Tidal Marsh & - \\
\hline
\end{tabular}

Date, time, and location (latitude and longitude) of fish and zooplankton samples (tow \#) collected in northern San Francisco Estuary regions and habitats. + after a Tow \# indicates zooplankton samples that were used as positive controls. Fish Present indicates whether longfin smelt or Pacific herring were found $(F)$ in the fish sample or if neither fish was present (-).

180 (Model 2030R, low-flow rotor). At each sample site two tows were conducted consecutively:

181 one tow for molecular diet studies and a second for morphological diet studies. Larval fish and 182 zooplankton from one tow were immediately preserved in 95\% non-denatured ethyl alcohol 
$183(\mathrm{EtOH})$ and placed on ice for molecular diet analysis. The larval fish and zooplankton from the second tow were preserved in 2-4\% formaldehyde (final conc., vol:vol) for use primarily in a separate study examining the distribution and abundance of larval longfin smelt and Pacific

186 herring (Grimaldo et al., 2020), and for a study of the fish diets through morphological analysis.

187 Upon return to the laboratory and within 12 hours, samples for molecular analysis were stored at

$188-20{ }^{\circ} \mathrm{C}$; EtOH was exchanged to fresh $\mathrm{EtOH}$ within 24 hours of collection to maintain sample

189 integrity (Bucklin 2000).

190 Fish Sample Processing

$191 \quad$ Fish in samples were sorted and identified to species. All longfin smelt were processed

192 for sequencing. Up to 20 Pacific herring per sample were processed for analysis from each of

193 four tows where both fish species were present and at least one species was relatively abundant

194 (>10 individuals) (Table 2). We isolated selected fish from the sample, photographed and

195 measured the entire body, and visually determined if prey were visible without dissection.

196 Dissection tools were UV sterilized between samples, and wiped clean between fish within the

197 same sample. For each larva, the entire digestive tract from the base of the gills to the anus was

198 carefully separated from the body tissue using a fine probe and forceps. The digestive tract was

199 then placed in a sterile tube containing 95\% EtOH for DNA extraction.

$200 \quad$ Fishes from four tows were analyzed for both dDNA and morphological diet analysis of

201 longfin smelt larvae to compare results of each method. For morphological diet analysis, each

202 formaldehyde-preserved larva was examined under a dissecting microscope and prey items in the

203 entire digestive tract were identified, counted, and measured. Calanoid copepods, Limnoithona

204 tetraspina, and adult Acanthocyclops spp. were identified to species. Other cyclopoids and

205 harpacticoids were identified to order. Copepod nauplii were not further identified (labeled here

206 as unidentified copepoda). Non-copepod prey were identified to the lowest taxonomic level

207 possible.

DNA Extraction

We desiccated the fish guts using a vacuum centrifuge at room temperature for a

210 maximum of 1.25 hours. The desiccated guts were then resuspended in warmed buffer ATL

211 (Qiagen) and vortexed, and guts from fish larger than $10 \mathrm{~mm}$ were pestle ground to facilitate

212 tissue breakdown. One negative gut control was created along with each batch of gut extractions

$213(\mathrm{n}=3)$, consisting of a sterile microcentrifuge tube with the same clean ethanol that was used for 
Table 2. Samples where fish were collected, along with associated metadata on fish abundance, number of samples sequenced, and 215 fish size.

\begin{tabular}{|c|c|c|c|c|c|c|c|c|c|c|c|c|c|}
\hline \multirow[b]{2}{*}{ Date } & \multirow[b]{2}{*}{ Tow } & \multirow[b]{2}{*}{ Region } & \multirow[b]{2}{*}{ Habitat } & \multicolumn{5}{|c|}{$\begin{array}{c}\text { Longfin Smelt } \\
\end{array}$} & \multicolumn{5}{|c|}{ Pacific Herring } \\
\hline & & & & $\begin{array}{c}\text { Fish } \\
\text { sample }^{-1}\end{array}$ & $\begin{array}{c}\text { Fish } \mathbf{m}^{-} \\
3\end{array}$ & Seq. & $\begin{array}{c}\text { Length } \\
\pm \mathrm{SD} \\
(\mathrm{mm})\end{array}$ & $\begin{array}{c}\text { Length } \\
\text { Range } \\
(\mathbf{m m})\end{array}$ & $\begin{array}{c}\text { Fish } \\
\text { sample }^{-}\end{array}$ & $\begin{array}{c}\text { Fish } \\
\mathbf{m}^{-3}\end{array}$ & Seq. & $\begin{array}{c}\text { Length } \\
\pm \text { SD } \\
(\mathrm{mm})\end{array}$ & $\begin{array}{c}\text { Length } \\
\text { Range } \\
\text { (mm) }\end{array}$ \\
\hline $3 / 7 / 17$ & 6 & Suisun & $\begin{array}{c}\text { Tidal } \\
\text { Marsh }\end{array}$ & 1 & 0.0184 & 1 & 7 & 7 & 0 & - & - & - & - \\
\hline $3 / 7 / 17$ & 13 & $\begin{array}{c}\text { San } \\
\text { Pablo }\end{array}$ & $\begin{array}{l}\text { Channel } \\
\text { Bottom }\end{array}$ & 21 & 0.1489 & 21 & $8 \pm 2$ & $7-17$ & 36 & 0.255 & 20 & $12 \pm 3$ & $10-19$ \\
\hline $3 / 9 / 17$ & 14 & $\begin{array}{c}\text { San } \\
\text { Pablo }\end{array}$ & $\begin{array}{l}\text { Channel } \\
\text { Bottom }\end{array}$ & 4 & 0.0487 & 3 & $10 \pm 5$ & $6-15$ & 23 & 0.28 & - & $10 \pm 4$ & $8-22$ \\
\hline $3 / 9 / 17$ & 15 & $\begin{array}{c}\text { San } \\
\text { Pablo }\end{array}$ & $\begin{array}{l}\text { TidalMa } \\
\text { rsh }\end{array}$ & 42 & 0.2973 & $21^{*}$ & $11 \pm 3$ & $8-20$ & 20 & 0.142 & 20 & $16 \pm 6$ & $10-28$ \\
\hline $3 / 9 / 17$ & 16 & $\begin{array}{l}\text { San } \\
\text { Pablo }\end{array}$ & $\begin{array}{l}\text { Channel } \\
\text { Surface }\end{array}$ & 8 & 0.0584 & 8 & $15 \pm 4$ & $8-20$ & 86 & 0.628 & - & $16 \pm 5$ & $10-24$ \\
\hline $3 / 9 / 17$ & 17 & $\begin{array}{c}\text { San } \\
\text { Pablo }\end{array}$ & $\begin{array}{l}\text { Channel } \\
\text { Surface }\end{array}$ & 0 & - & - & - & - & 18 & 0.145 & - & $18 \pm 4$ & $9-22$ \\
\hline $3 / 22 / 17$ & 20 & Suisun & Shoal & 46 & 0.3872 & $23^{*}$ & $8 \pm 1$ & $6-10$ & 0 & - & - & - & - \\
\hline $3 / 22 / 17$ & 21 & Suisun & $\begin{array}{l}\text { Channel } \\
\text { Bottom }\end{array}$ & 3 & 0.0216 & 3 & $13 \pm 4$ & $9-17$ & 4 & 0.029 & - & $14 \pm 3$ & $11-16$ \\
\hline $3 / 22 / 17$ & 22 & Suisun & $\begin{array}{l}\text { Channel } \\
\text { Bottom }\end{array}$ & 3 & 0.0229 & 3 & $8 \pm 1$ & $8-9$ & 0 & - & - & - & - \\
\hline $3 / 23 / 17$ & 23 & Suisun & Shoal & 1 & 0.0076 & 1 & 7 & 7 & 13 & 0.099 & 13 & $16 \pm 4$ & $11-25$ \\
\hline $3 / 23 / 17$ & 24 & $\begin{array}{c}\text { San } \\
\text { Pablo }\end{array}$ & Shoal & 25 & 0.1181 & 25 & $14 \pm 3$ & $9-20$ & 349 & 0.128 & 20 & $20 \pm 7$ & $11-31$ \\
\hline $3 / 23 / 17$ & 25 & $\begin{array}{c}\text { San } \\
\text { Pablo }\end{array}$ & $\begin{array}{l}\text { Tidal } \\
\text { Marsh }\end{array}$ & 0 & - & - & - & - & 43 & 0.142 & - & $16 \pm 5$ & $10-30$ \\
\hline $3 / 23 / 17$ & 26 & $\begin{array}{c}\text { San } \\
\text { Pablo }\end{array}$ & $\begin{array}{l}\text { Tidal } \\
\text { Marsh }\end{array}$ & 2 & 0.0147 & 2 & $13 \pm 3$ & $12-15$ & 87 & 0.638 & - & $18 \pm 6$ & $10-30$ \\
\hline
\end{tabular}

The total number (Fish sample ${ }^{-1}$ ) and abundance (Fish $\mathrm{m}^{-3}$ ) of fish collected in each sample, with the number of fish guts sequenced (Seq.), mean and SD of length $(\mathrm{mm})$ and length range of fishes of each type. ${ }^{*}$ sequenced samples contained pooled extract from two fish guts 
217 the gut preservation, and processed in the same way as the guts. A standard protocol (DNeasy

218 Blood and Tissue kit, Purification of Total DNA from Animal Tissues, Qiagen) was followed with

219 an overnight incubation and addition of the recommended RNAse A step. Extracts were eluted

220 twice with $50 \mu \mathrm{L}(100 \mu \mathrm{L}$ total $)$ into a single tube and placed in a $-80{ }^{\circ} \mathrm{C}$ freezer.

221 We then extracted DNA from a quantitative subsample from each zooplankton sample for 222 comparison to the prey found in the diet. Each subsample volume was calculated so that 1)

223 material remained in the sample for morphological identification and barcoding if needed later;

224 2) the volume of equivalent estuarine water extracted was equal across samples; and 3) the

225 volume extracted was large enough to adequately represent the ambient zooplankton assemblage

226 at densities typical of the northern estuary. Zooplankton subsamples were vacuum-concentrated

227 onto bleach-sterilized $100 \mu \mathrm{m}$ nitex filters to remove sample ethanol. Filters were transferred

228 into $15 \mathrm{~mL}$ centrifuge tubes for extraction following the OMEGA EZNA soil DNA kit following

229 the protocol for 250-1000 mg samples. This kit was chosen to minimize inhibition due to high

230 concentrations of sediment in some samples. When the subsample was thick with material, it was

231 split onto multiple filters for DNA extraction and the elution products from all splits of the same

232 subsample were combined. In each of the four batches of DNA extractions a negative extraction

233 control was included, consisting of a bleach-sterilized filter processed in the same way as the

234 zooplankton samples.

235 After extracting quantitative subsamples from the zooplankton tow samples, we used a

236 subset of zooplankton tows to generate positive controls. These came from zooplankton tows 12,

$23713,15,16,20,23,26$ and 29, and represented channel, shoal, and marsh habitats in both San

238 Pablo Bay and Suisun Bay (Table 1). Each sample was sorted to isolate at least one individual of

239 each unique organism found; organisms were then identified to the lowest taxonomic level, and

240 transferred into a single vial containing all sorted organisms for the sample. DNA extraction of

241 positive controls was performed using the same DNeasy Tissue Extraction kit (Qiagen) protocol

242 as described above, including grinding the organisms in each sample with a sterile pestle prior to 243 extraction.

244 In two fish samples, each containing $>40$ longfin larvae (tows 15 and 20), we pooled

245 DNA extracts from pairs of larvae from the same sample. A total of 111 extracts were generated

246 for longfin smelt larvae. Each of the guts from the 73 herring was sequenced individually. Bulk

247 zooplankton was sequenced from 32 zooplankton samples, including the samples collected 
248 where longfin smelt and Pacific herring larvae were present ("fish" zooplankton) as well as

249 samples where these two larval fishes were not present in concurrent fish samples ("no fish"

250 zooplankton); analyzing both "fish" and "no fish" zooplankton samples allowed us to assess for

251 possible differences in the zooplankton prey assemblages where larval fishes were present.

\section{Library Preparation and Sequencing}

We sequenced zooplankton and fish gut samples on two separate MiSeq sequencing runs to recover more sequences per sample from the smaller number of zooplankton samples, since to maximize sequencing coverage in the large number of fish guts. For each sequencing run,

258 DNA in extracts was first amplified (PCR1) with the following universal metazoan primers

259 (Table 3) that included standard Nextera Transposase Adapters (Illumina) to target the mtCOI 260 gene: mjHCO2198 (modified from Geller et al., 2013), and mlCOIintF (Leray et al., 2013). The mjHCO2198 primers were modified from Geller et al., (2013) because we found the inosine

262 bases to be incompatible with high-fidelity DNA polymerase. In addition to using the universal

263 mtCOI primers, fish-gut extracts were amplified with an annealing-inhibiting primer (blocking

264 primer; 10-fold higher concentration), which were designed for this study to reduce amplification

265 of DNA from the fish (e.g., Vestheim \& Jarman 2008): Lfs_COIBlk_668R for longfin smelt and

266 Clp_COIBlk_668R for Pacific herring. Blocking primers included a phosphorothioate bond at

267 the 3' end to prevent exonuclease degradation of the C3-spacer by the high-fidelity polymerase.

268 Table 3. PCR and blocking primers used in this study.

\begin{tabular}{|c|c|c|c|}
\hline Primer ID & Sequence (5' --- 3') & Reference & Role \\
\hline mjHCO2198 & $\begin{array}{l}\text { TAA ACY TC W GGR TGW CCR } \\
\text { AAR AAY CA }\end{array}$ & This paper & Metabarcoding \\
\hline mlCOIintF & $\begin{array}{l}\text { GGW ACW GGW TGA ACW GTW } \\
\text { TAY CCY CC }\end{array}$ & Leray et al 2013 & $\begin{array}{l}\text { Metabarcoding \& } \\
\text { barcoding }\end{array}$ \\
\hline Lfs_COIBlk_668R & $\begin{array}{l}\text { GTG ACC GAA GAA TCA GAA TAG } \\
\text { ATG CTG G*/3SpC3/ }\end{array}$ & This paper & Longfin smelt blocker \\
\hline Clp_COIBlk_668R & $\begin{array}{l}\text { GTG ACC GAA GAA TCA GAA TAG } \\
\text { GTG TTG } \mathrm{G}^{*} / 3 \mathrm{SpC} 3 /\end{array}$ & This paper & Clupeid blocker \\
\hline jgHCO2198 & $\begin{array}{l}\text { TAI ACY TCI GGR TGI CCR AAR } \\
\text { AAY CA }\end{array}$ & Geller et al 2013 & Individual barcoding \\
\hline LCO1490 & $\begin{array}{l}\text { GGT CAA CAA ATC ATA AAG ATA } \\
\text { TTG G }\end{array}$ & $\begin{array}{l}\text { Folmer et al } \\
1994\end{array}$ & Individual barcoding \\
\hline
\end{tabular}

* denotes phosphorothioate bond to prevent exonuclease degradation by the high-fidelity polymerase. 
The zooplankton assemblage and associated negative controls, including two PCR negative controls, were sequenced on the first sequencing run. Each reaction in PCR1 for the

272 first sequencing run was prepared with triplicate PCR amplifications for each DNA extract with 273 the following reaction setup: $2 \mu \mathrm{L}$ of $5 \mathrm{x}$ Kapa fidelity buffer, $0.3 \mu \mathrm{L}$ dNTPs $(10 \mathrm{mM}), 1 \mathrm{ng}$ 274 bovine serum albumin (BSA, to minimize inhibition), $0.3 \mu \mathrm{M}$ of each universal primer, $0.2 \mu \mathrm{L}$ 275 Kapa HiFi Polymerase, and $1 \mu \mathrm{L}$ of DNA extract, with nuclease-free $\mathrm{H}_{2} \mathrm{O}$ added to a total 276 volume of $10 \mu \mathrm{L}$. The PCR 1 thermal-cycling protocol included initial denaturation at $95{ }^{\circ} \mathrm{C}$ for 2773 minutes, followed by 25 cycles of $98{ }^{\circ} \mathrm{C}$ for 20 seconds, $46{ }^{\circ} \mathrm{C}$ for 30 seconds, and $72{ }^{\circ} \mathrm{C}$ for 27815 seconds, with a final $72{ }^{\circ} \mathrm{C}$ extension for 4 minutes. Triplicate products from PCR 1 were 279 pooled before indexing the products in the second PCR. The second PCR was performed with 280 the following conditions: $5 \mu \mathrm{L}$ of $5 \mathrm{x}$ Kapa fidelity buffer, $0.75 \mu \mathrm{L}$ dNTPs $(10 \mathrm{mM}), 0.5 \mathrm{mM}$ $281 \mathrm{MgCl}_{2}, 1 \mathrm{ng} \mathrm{BSA}, 0.5 \mu \mathrm{M}$ of each indexing primer, $0.5 \mu \mathrm{L}$ of Kapa HiFi Polymerase, and $2.5 \mu \mathrm{L}$ 282 of pooled PCR1 product with nuclease-free $\mathrm{H}_{2} \mathrm{O}$ added to a total volume of $25 \mu \mathrm{L}$. The PCR2 283 thermal-cycling protocol included initial denaturation at $95{ }^{\circ} \mathrm{C}$ for 3 minutes, followed by 8 cycles of $98{ }^{\circ} \mathrm{C}$ for 30 seconds, $55^{\circ} \mathrm{C}$ for 30 seconds, and $72{ }^{\circ} \mathrm{C}$ for 30 seconds, with a final 72 ${ }^{\circ} \mathrm{C}$ extension for 5 minutes. Gel electrophoresis indicated strong product amplification. We performed a single Serapure bead cleanup (Bronner et al., 2013; Rohland \& Reich 2012) to remove remaining primers and dNTPs. After a Qubit HS assay was used to quantify all zooplankton products, equimolar concentrations of each barcoded sample $(7 \mathrm{nM})$ were pooled to 289 a single library tube. After denaturation, the final library was sequenced at the San Francisco 290 State University Genetics Transcriptomics Analysis Core facility on an Illumina MiSeq platform 291 using paired-end sequencing (MiSeq Reagent kit V2) with a 20\% PhiX spike-in control to 292 improve quality of low-diversity samples.

For the second sequencing run which included the fish gut samples, gut extraction

294 controls, positive controls, and four PCR negative controls, we used Kapa HiFi Hotstart 295 Readymix (Kapa Biosystems) to simplify the mastermix protocol, and amplified each DNA 296 extract in triplicate in PCR1 with the thermal cycling conditions described above but with 35 297 cycles of the denaturation, annealing, extension steps, and the following reaction setup: $5 \mu \mathrm{L}$ 298 Kapa 2x HiFi Hotstart Readymix, $0.3 \mu \mathrm{M}$ of each universal primer, $3 \mu \mathrm{M}$ of the fish-specific 299 blocking primer, $1 \mathrm{ng} \mathrm{BSA}, 2 \mu \mathrm{L}$ DNA extract, and the remaining volume of nuclease-free $\mathrm{H}_{2} \mathrm{O}$ 
300 for a $10 \mu \mathrm{L}$ reaction per replicate. Triplicate products from PCR1 were pooled, and PCR2 was

301 performed to index each library with the following conditions: $12.5 \mu \mathrm{L}$ of Kapa 2x HiFi Hotstart

302 Readymix, $0.5 \mu \mathrm{M}$ of each indexing primer, $1 \mathrm{ng} \mathrm{BSA}$, and $2.5 \mu \mathrm{L}$ of pooled PCR1 product, and

303 an appropriate volume of nuclease-free $\mathrm{H}_{2} \mathrm{O}$ for a $25 \mu \mathrm{L}$ reaction per sample. Bead cleanup was

304 performed to remove both large non-target and small non-target DNA fragments (Bronner et al.,

305 2013) from the amplified gut samples. The DNA quantity in indexed, bead-cleaned PCR

306 products was normalized using the SequalPrep Normalization Plate Kit (Applied Biosystems) to

307 obtain 250 ng PCR product per well. Five $\mu \mathrm{L}$ of each product were pooled to create the final

308 library provided to UC Davis Sequencing facility. The final library was run on an Illumina

309 MiSeq platform using paired-end sequencing (MiSeq Reagent kit V2) with a 35\% PhiX spike-in

310 control to improve the quality of the low sequence diversity expected in the sequenced fish gut

311 samples.

312

313 Sequence Analysis

314 Sequence data were processed with custom scripts written to analyze Illumina-generated

315 metabarcoding data. Initial processing of these data employed primer trimming with cutadapt

316 (v2.1), read pairing with pear (V0.9.11; Zhang et al., 2014), and following the DADA2 pipeline

317 (v1.10.1; Callahan et al., 2016). The DADA2 pipeline filters out sequencing errors, dereplicates

318 sequences, identifies chimeras, merges paired-end reads, and identifies amplicon sequence

319 variants (ASVs, 100\% identical sequence groups).

320 We performed further quality filtering of the complete set of ASVs in several steps. First,

321 we looked at the distribution of sequence lengths in the entire set of ASVs. Sequences that were

$322313 \mathrm{bp}$ in length were kept for further analysis to minimize false positives and remove spurious

323 sequences from the dataset (size-based filtering). All remaining ASVs were annotated by

324 BLASTn to the NCBI nucleotide database (downloaded 21 March 2019). The top hit ( $\geq 97.0 \%$

325 identity, $\geq 90 \%$ query coverage) was retained from this set, and any ASVs that remained with

$326<97 \%$ identity were then processed with the MIDORI classifier (Machida et al., 2017) using the

327 MIDORI-unique reference dataset (updated 21 February 2018) and RDP Classifier (Wang et al.,

328 2007) with a cutoff of $80 \%$ bootstrap confidence. We assigned ASVs with $<80 \%$ bootstrap

329 confidence to the "unknown" category. We then used taxonomy-based filtering on classified 
ASVs: any sequences classified as non-eukaryotes (98 ASVs, 952 reads) as well as nonactinopterygian chordates (3 ASVs, 37 reads) were excluded from the dataset (Suppl. Table 1), and sequences identified as the predator species (longfin smelt or Pacific herring) in the same species' gut were also excluded from each corresponding gut sample (51,455 longfin smelt and 50,130 Pacific herring reads total). Remaining eukaryotic sequences not classified as metazoans were lumped into the "non-metazoan" group for further analysis.

The sequences were analyzed to identify gaps in the Genbank database for taxa known to be in the estuary and that may have been assigned to the "unknown" category. Cyclopoid and harpacticoid copepods were abundant in the plankton samples but poorly resolved in the database. We therefore sequenced DNA barcodes of individual copepods to fill these gaps. Individual cyclopoids $(n=31)$ and harpacticoids $(n=11)$ were selected from the bulk zooplankton samples and morphologically identified to the lowest possible taxonomic level. Individuals were cleaned of external debris, a voucher photo was taken of each organism, and total DNA was extracted following the standard Qiagen DNeasy DNA Extraction from Tissues protocol. DNA barcodes (mtCOI) were amplified in PCR with the following reaction setup: $10 \mu \mathrm{L}$ MangoMix DNA Polymerase (Bioline), $0.25 \mu \mathrm{M}$ of each primer, $5 \mu \mathrm{L}$ DNA extract, and nuclease-free $\mathrm{H}_{2} \mathrm{O}$ for a $20 \mu \mathrm{L}$ reaction. Two primer sets were used (Table 3). All extracts were first amplified with universal mtCOI primers LCO1490 (Folmer et al., 1994) and jgHCO2198 (Geller et al., 2013). Individuals that did not amplify with the first primer set were then tested with both metabarcoding primers used in this study. PCR products were cleaned (ExoSAP-IT, Affymetrix), ligated, cloned, and sequenced using standard protocols (ABI 3500 Perkin-Elmer capillary sequencer; BigDye v3.1). DNA sequences were compared to the NCBI Genbank database using BLASTn and any sequences that did not result in a $>97 \%$ ID match were added to our local database and BLASTn-matched to ASVs in the current dataset.

\section{Statistical Analysis}

Statistical analyses were performed in R (R Core Team 2019). Environmental variables were standardized and a Principal Component Analysis (PCA) was used to evaluate environmental variation among sampling events (stats R package). Differences in beta diversity across sample types were assessed with a non-metric multidimensional scaling (NMDS) analysis using Bray-Curtis dissimilarity on the ASV abundances, keeping taxa that were seen more than 
once in $>1 \%$ of samples (removed 5237 ASVs) to assess for similarity among the assemblages in the diets and zooplankton samples.

A Permutational Analysis of Variance (PERMANOVA) was used to assess differences in beta diversity of ASVs among fish species, tow number, sampling region (San Pablo Bay or Suisun Bay), and sampling habitat (channel surface, shoal, tidal marsh). A type III sum of squares PERMANOVA was performed on the normalized ASV abundances using the adonis function (vegan package; Oksanen et al., 2019) with 999 permutations, and tested for interactions among all terms. For this analysis, the ASV abundances were normalized by rarefying to the median sequencing depth of 228 found for fish gut samples. Tests for homogeneity of dispersion among groups, an assumption of PERMANOVA, were performed using betadisper on the Bray-Curtis distance matrix (phyloseq package; McMurdie \& Holmes 2013) of sample ASVs for each group of interest: fish species, tow number, sampling region, and 373 habitat. type (longfin smelt, Pacific herring, and zooplankton). Percentage FO is based on presence or absence of a prey item and is the percentage of the total number of a sample type with a given prey item (Baker et al., 2014; Hynes 1950). The FO of longfin smelt prey identified through dDNA analysis were compared to the FO of prey identified through morphological diet analysis (full study to be published elsewhere) in the four fish samples specifically chosen for this comparison. relative abundance of a species' DNA in each sample. The RRA gives each gut or zooplankton sample equal weight in the view of overall sequence abundance across samples of each type. $R R A_{i}$ for food item $i$ was calculated as:

where $n_{i, k}$ is the number of sequences of food item $i$ in sample $k, S$ is the total number of samples, and $T$ is the number of food items (taxa).

$$
R R A_{i}=\frac{1}{S} \sum_{k=1}^{S} \frac{n_{i, k}}{\sum_{i=1}^{T} n_{i, k}} \times 100 \%
$$


different taxa between zooplankton samples and diet samples. Differential abundance was calculated for the subset of taxa that overlapped between the fish diets and zooplankton assemblage. A likelihood ratio test (analogous to an ANOVA) was used to compare the relative abundance of each prey type (species-level or best identification) in the diet to that in the zooplankton assemblage with a maximum false discovery rate of 5\%. The DESeq2 analysis accounts for differences in sequencing depth inherent in high-throughput sequencing, and when the observed sequence abundance is zero in one group, the likelihood ratio test utilizes a prior distribution on the log fold changes to provide differential abundance estimates (Love et al., 2014).

We used Schoener's index (Schoener 1970; also known as Czekanowski's index) to characterize overlap in diets between the two fish species (Feinsinger et al., 1981; Keppeler et al., 2015 Waraniak et al., 2019). Values of this index range from 0 (no overlap) to 1 (complete overlap) and values above 0.6 are considered biologically meaningful (Wallace 1981).

403 Schoener's index was calculated using the RRA values of each prey item for longfin smelt and 404 Pacific herring.

405

406

\section{$\underline{\text { Results }}$}

Values of water turbidity, salinity, and chlorophyll were higher in some San Pablo Bay samples than in the Suisun Bay samples collected between February and April 2017. Across all sample regions and dates, water temperature ranged from 10 to 19 (median 14.4 ) ${ }^{\circ} \mathrm{C}$, salinity ranged from 0.07 to 15.2 (median 0.2, Practical Salinity Scale), dissolved oxygen ranged from 8.3 to 13.9 (median 9.4) $\mathrm{mg} \mathrm{L}^{-1}$, chlorophyll ranged from 0.5 to 9.9 (median 4.4) $\mu \mathrm{g} \mathrm{Chl} \mathrm{L}^{-1}$, and turbidity ranged from 9 to 153 (median 45) NTU. In general, water temperature increased in both regions over time and salinity increased over the first month of study in San Pablo Bay, from 0.1 on 28 February to 5.8 PPT on 23 March. In the samples where fishes were collected, water temperature ranged from 11 to 16 (median 14$)^{\circ} \mathrm{C}$, salinity ranged from 0.1 to 15.2 (median 1.2) PSU, dissolved oxygen ranged from 8.6 to 10.3 (median 9.5) $\mathrm{mg} \mathrm{L}^{-1}$, chlorophyll ranged from 2.2 to 9.7 (median 7.7) $\mu \mathrm{g} \mathrm{Chl} \mathrm{L}{ }^{-1}$, and turbidity ranged from 13 to 153 (median 85) NTU (Suppl. Figure 1).

The first two principal components of environmental data explained $75 \%$ of the variation among the samples (Figure 2). The first principal component (52\% of variation) shows 
separation of samples primarily by dissolved oxygen (negative) and chlorophyll (positive). The second principal component (23\% of variation) distinguishes sample salinity (negative) from oxygen, turbidity and chlorophyll (positive). Samples were grouped loosely by region (San Pablo Bay vs. Suisun Bay). Neither environmental variables nor sampling region were useful in distinguishing samples containing one or both species of fish from those without these fish.

A total of 155 longfin smelt larvae were collected from 11 of the 32 sampling events between February and May 2017; only four samples contained > 10 longfin smelt (Table 2). To allow for a comparative analysis of diets, a total of 73 Pacific herring larvae were isolated from the four samples containing both species. Lengths of sequenced longfin smelt ranged from 6.2 to $20.0 \mathrm{~mm}(10.4 \pm 3.6$, mean $\pm \mathrm{SD})$, and lengths of sequenced Pacific herring were from 8.9 to $22.8 \mathrm{~mm}(16.1 \pm 5.9$, mean $\pm \mathrm{SD})$.

\section{Fish Diet and Community Metabarcoding}

In total, high-throughput mtCOI amplicon sequence data were generated from 220 zooplankton and fish gut samples, six negative DNA extraction controls, and four negative PCR controls. A total of $10.6 \times 10^{6}$ raw reads were recovered from the two sequencing runs. After DADA2 processing, size-based filtration, and taxonomic filtration, $4.2 \times 10^{6}$ sequence reads remained containing a total of $9.6 \times 10^{3} \mathrm{ASVs}$ (Suppl. Table 2). Of the total sequence reads that remained, $82.7 \%$ were metazoan, $4.9 \%$ were non-metazoan, and $12.4 \%$ were classified as "unknown". Of the total ASVs that remained, 41.3\% were metazoan, 3.0\% were non-metazoan, and $55.7 \%$ were classified as "unknown".

Among the metazoan DNA sequences, predator DNA for each fish species accounted for $0.7 \%-100 \%$ (median $73.5 \%$ ) of the total sequence reads for each longfin smelt gut and $0.2 \%-$ 100\% (median 82.3\%) for each Pacific herring gut. There were 4-4,206 (non-predator) metazoan sequence reads (median 532) from each longfin smelt gut sample and $2-5,060$ metazoan reads (median 824) from each Pacific herring gut sample. Sixteen (14\% of the total) longfin smelt guts were considered empty (14 with 100\% predator DNA, two with no DNA) and 10 (14\% of the total) Pacific herring guts were considered empty (all with 100\% predator DNA).

We recovered a 40 -fold greater total reads in the zooplankton samples $\left(4.0 \times 10^{6}\right.$ reads $)$ than in the fish guts $\left(0.1 \times 10^{6}\right.$ reads): sequencing depth was higher in the first sequencing run 
than in the second. Sequence diversity, as estimated by the number of ASVs, was also roughly 50 -fold higher in zooplankton samples $\left(9.47 \times 10^{3} \mathrm{ASVs}\right)$ than in fish guts $\left(0.19 \times 10^{3} \mathrm{ASVs}\right)$. As a result, the average number of sequences per ASV was roughly equal between the fish guts 454 and the zooplankton samples.

In positive control samples, DNA sequencing results provided equal or higher resolution of all morphologically identified taxa, with a few exceptions (Table 4). Several species were resolved with DNA that could not be identified to species using morphology: A. americanus, $A$. robustus, A. vernalis, Acanthocyclops sp., and another genetic group of unidentified cyclopoids. Multiple Diptera were resolved with DNA as well, including Chironominae sp., Paratanytarsus grimmii, and another genetically distinct but unidentified dipteran. The presence of Oithona

461 davisae, ciliates, cumaceans, gastropods, nematodes, polychaetes, and rotifers, identified in the

462 samples by morphology, could not be confirmed with DNA (Table 4). Many of these taxa are not 463 well represented in the genetic database (NCBI) and thus may have been sequenced and lumped 464 into broader groups such as the "unknown” group or unidentified Arthropoda.

We obtained sequences from 22 of the 31 cyclopoid and 11 harpacticoid copepods that 466 were individually DNA barcoded, corresponding to 10 unique barcodes that we added to our 467 database to improve resolution of "unknown" DNA sequences (Table 5). Ten individuals did not 468 amplify, and 10 others resulted in sequences that did not correspond to the identified organism 469 (Suppl. Table 3). Of the 10 additional unique DNA barcodes, one corresponded to the cyclopoid 470 copepod Limnoithona tetraspina which was added to the database, two barcodes confirmed the 471 presence of the two cyclopids, Acanthocyclops americanus and Mesocyclops pehpeiensis, and 472 the remaining seven barcodes gave "unknown" ASVs a higher level of taxonomic resolution

473 (Cyclopoida A, B, or Harpacticoida A, B) whose tentative morphological identification will 474 require additional verification of species before they can be added to the public database (NCBI).

475 In our study samples, 396 ASVs corresponded to L. tetraspina, two ASVs corresponded to 476 Cyclopoida A, one ASV corresponded to Cyclopoida B, 137 ASVs corresponded to 477 Harpacticoida A, and two ASVs corresponded to Harpacticoida B. The individual barcodes 478 assigned to $A$. americanus and $M$. pehpeiensis corresponded to 379 and $1 \mathrm{ASV}$, respectively, for 479 these two species in our study samples. 
bioRxiv preprint doi: https://doi.org/10.1101/2020.10.18.344440; this version posted October 18, 2020. The copyright holder for this preprint (which was not certified by peer review) is the author/funder. All rights reserved. No reuse allowed without permission.

480 Table 4. Positive controls comparing morphological ID (Morph ID) to the lowest taxonomic 481 level with resulting DNA sequences (DNA ID). Match (M): DNA and Morph ID are a match, 482 Unknown (U): ID does not have a clear match and corresponds to multiple types of organisms, 483 Extra (E): not identified morphologically and DNA provided extra information. Unid:

484 Unidentified to a higher level. N/A: ID for a column is unknown or not present.

\begin{tabular}{|c|c|c|}
\hline $\mathbf{M}, \mathbf{U}$, or $\mathbf{E}$ & DNA ID & Morph ID \\
\hline $\mathrm{M}$ & Bosmina liederi & Bosmina sp. \\
\hline M & Bosminidae sp. & Bosmina sp. \\
\hline M & Ceriodaphnia laticaudata & Ceriodaphnia sp. \\
\hline M & Daphnia sp. & Daphnia sp. \\
\hline M & Eurytemora carolleeae & Eurytemora carolleeae \\
\hline M & Limnoithona tetraspina & Limnoithona tetraspina \\
\hline $\mathrm{E}$ & Plumatella repens & $\mathrm{N} / \mathrm{A}$ \\
\hline $\mathrm{U}$ & N/A & Oithona davisae \\
\hline M & Pseudodiaptomus forbesi & Pseudodiaptomus forbesi \\
\hline M & Sinocalanus tenellus & Sinocalanus doerii \\
\hline M & Tortanus dextrilobatus & Tortanus dextrilobatus \\
\hline M & Tortanus derjugini & Tortanus dextrilobatus \\
\hline M & Tortanus sp. & Tortanus dextrilobatus \\
\hline M & Gammarus daiberi & Unid. Amphipod \\
\hline M & Macoma petalum & Unid. Bivalvia \\
\hline M & Osphranticum labronectum & Unid. Calanoid \\
\hline M & Amphibalanus improvisus & Unid. Cerripedia \\
\hline $\mathrm{U}$ & N/A & Unid. Ciliate \\
\hline M & Chydorus brevilabris & Unid. Cladocera \\
\hline M & Pseudochydorus globosus & Unid. Cladocera \\
\hline M & Simocephalus exspinosus & Unid. Cladocera \\
\hline $\mathrm{U}$ & N/A & Unid. Cumacea \\
\hline M & Acanthocyclops americanus & Unid. Cyclopoida \\
\hline M & Acanthocyclops robustus & Unid. Cyclopoida \\
\hline M & Acanthocyclops sp. & Unid. Cyclopoida \\
\hline M & Acanthocyclops vernalis & Unid. Cyclopoida \\
\hline M & Unid. Cyclopoida & Unid. Cyclopoida \\
\hline M & Skistodiaptomus pallidus & Unid. Diaptomidae \\
\hline M & Chironominae sp. & Unid. Diptera \\
\hline M & Unid. Diptera & Unid. Diptera \\
\hline M & Paratanytarsus grimmii & Unid. Diptera \\
\hline $\mathrm{U}$ & N/A & Unid. Gastropoda \\
\hline M & Unid. Harpacticoida & Unid. Harpacticoid \\
\hline M & Hydra oligactis & Unid. Hydrozoa \\
\hline M & Hydra sp. & Unid. Hydrozoa \\
\hline M & Unid. Insecta & Unid. Insecta \\
\hline M & Hyperacanthomysis longirostris & Unid. Mysid \\
\hline $\mathrm{U}$ & N/A & Unid. Nematoda \\
\hline M & Amphichaeta sannio & Unid. Oligochaeta \\
\hline M & Tubificoides fraseri & Unid. Oligochaeta \\
\hline M & Unid. Podocopida & Unid. Ostracoda \\
\hline $\mathrm{U}$ & N/A & Unid. Polychaeta \\
\hline $\mathrm{U}$ & N/A & Unid. Rotifera \\
\hline $\mathrm{U}$ & Unid. Arthropoda & N/A \\
\hline \multirow[t]{2}{*}{$\mathrm{U}$} & Unknown & $\mathrm{N} / \mathrm{A}$ \\
\hline & Non-metazoans & \\
\hline M & Melosira ambiqua & Unid. diatom \\
\hline E & Dinobryon divergens & N/A \\
\hline
\end{tabular}


Table 5. DNA barcoded cyclopoid and harpacticoid copepods, with their tentative morphological identification (ID), the name applied to the ASVs that matched the morphological ID in this study, the best ID in NCBI, \% identity of best NCBI match, NCBI best match accession number if $>97 \%$ identity, number of ASVs that matched that sequence type, and the number of individuals that were of that sequence type (n).

\begin{tabular}{|c|c|c|c|c|c|c|c|}
\hline Order & $\begin{array}{c}\text { Tentative } \\
\text { Morphological } \\
\text { ID } \\
\end{array}$ & $\begin{array}{c}\text { Name Applied } \\
\text { to ASVs }\end{array}$ & $\begin{array}{c}\text { Best Database } \\
\text { ID }\end{array}$ & $\begin{array}{c}\% \\
\text { Match } \\
\text { Best } \\
\end{array}$ & Accession \# & $\begin{array}{c}\# \\
>\mathbf{9 7 \%}\end{array}$ & $\mathbf{n}$ \\
\hline \multirow[t]{8}{*}{ Cyclopoida } & $\begin{array}{c}\text { Limnoithona } \\
\text { tetraspina }\end{array}$ & $\begin{array}{c}\text { Limnoithona } \\
\text { tetraspina }\end{array}$ & Diptera & 81.4 & MF172405 & 396 & $\overline{5}$ \\
\hline & $\begin{array}{c}\text { Acanthocyclops } \\
\text { americanus }\end{array}$ & $\begin{array}{c}\text { Acanthocyclops } \\
\text { americanus }\end{array}$ & $\begin{array}{c}\text { Acanthocyclops } \\
\text { americanus }\end{array}$ & 98.8 & MG230154 & 379 & 1 \\
\hline & $\begin{array}{c}\text { Mesocyclops } \\
\text { pehpeiensis }\end{array}$ & $\begin{array}{c}\text { Mesocyclops } \\
\text { pehpeiensis }\end{array}$ & $\begin{array}{l}\text { Mesocyclops } \\
\text { pehpeiensis }\end{array}$ & 100 & MK159096 & 1 & 1 \\
\hline & Homocyclops sp. & $\mathrm{N} / \mathrm{A}$ & Cyclopoida sp. & $99.4^{*}$ & MG449991 & 0 & 1 \\
\hline & $\begin{array}{c}\text { Macrocyclops } \\
\text { distinctus }\end{array}$ & $\mathrm{N} / \mathrm{A}$ & Cyclopoida sp. & $99.8^{*}$ & MG449984 & 0 & 1 \\
\hline & $\begin{array}{l}\text { Acanthocyclops } \\
\text { robustus }\end{array}$ & $\mathrm{N} / \mathrm{A}$ & Cyclopoida sp. & $99.8 *$ & MG449984 & 0 & 1 \\
\hline & $\begin{array}{l}\text { Acanthocyclops } \\
\text { robustus }\end{array}$ & $\mathrm{N} / \mathrm{A}$ & Cyclopoida sp. & $100 *$ & MG449984 & 0 & 1 \\
\hline & $\begin{array}{l}\text { Diacyclops } \\
\text { thomasi or A. } \\
\text { capillatus }\end{array}$ & $\mathrm{N} / \mathrm{A}$ & Diptera & 80.1 & MF476244 & 0 & 1 \\
\hline \multirow[t]{2}{*}{ Harpacticoida } & $\begin{array}{l}\text { Euterpina } \\
\text { acutifrons }\end{array}$ & Harpacticoida A & Hexapod & 74.1 & $\underline{\text { KJ083558 }}$ & 137 & 9 \\
\hline & Pseudobradya sp. & Harpacticoida B & $\begin{array}{l}\text { Metacyclopina } \\
\text { harpacticoidea }\end{array}$ & 79.5 & MH976658 & 4 & 1 \\
\hline
\end{tabular}

* indicates a high-level match (> 99\%) to an organism with a low level of taxonomic ID in the database (order-level).

NMDS analysis shows the ASV assemblages in the longfin smelt and Pacific herring

494 dDNA largely overlapped, while the zooplankton assemblages were tightly clustered in the

495 middle of the plot (Figure 3). The tight clustering of zooplankton samples in the center suggests

496 there were similar levels of diversity across zooplankton samples from different regions and

497 habitats, while the fish gut samples were more spread out, suggesting there were more

498 differences in diversity among different fish gut samples, in part due to fewer prey items sequenced in each gut sample, and with no discernible pattern. There was no separation between zooplankton assemblages where fish were present and where fish were not present. Seven

501 outliers had to be removed from the NMDS analysis: six Pacific herring and one longfin smelt 
gut. Each outlier contained $<5$ ASVs, five of which had fewer than 90 total reads, while the remaining two, both herring, had 1514 and 429 reads total.

Beta diversity tests (PERMANOVA) comparing the normalized ASVs in the dDNA of the two species suggest there may have been diet differences between the fishes $\left(\mathrm{F}_{1,131}=2.66, \mathrm{p}\right.$

$506=0.001)$ and between study regions $\left(\mathrm{F}_{1,131}=3.69, \mathrm{p}=0.001\right)$, but there were also interactions

507 between fish species and region $\left(\mathrm{F}_{1,137}=3.61, \mathrm{p}=0.001\right)$. The significant interaction may

508 indicate that there were both differences in diet between the two fish species as well as

509 differences in diet of the same species in the two regions, but it is hard to tell with the statistical

510 results alone. Differences among samples (tow number) and habitats were also tested, but the

511 dispersion (variance) was not homogeneous when grouping prey assemblages by tow number or

512 habitat $(\mathrm{p}=0.001)$.

513 Schoener's index of dietary overlap (alpha) calculated for longfin smelt and Pacific

514 herring diets overall was 0.66 , which is considered biologically meaningful $(>0.6)$ and supports

515 the NMDS results showing largely overlapping sequence assemblages between the two species.

516 For longfin smelt, we identified 116 ASVs of which 35 were classified with low confidence and

517 categorized as "unknown," representing 5\% of the total longfin smelt diet sequences. For Pacific

518 herring, we identified 99 ASVs of which 41 were classified as "unknown" and represented 11\%

519 of the total herring diet sequences.

Among ASVs classified to a known taxon, a variety of metazoan taxonomic groups were 521 detected in the larval fish guts, including arthropods, chordates, cnidarians, echinoderms, and 522 molluscs, and some non-metazoans. In total, 25 metazoan taxa were identified in longfin smelt 523 guts, 16 in Pacific herring, and 195 taxa in both types of zooplankton samples (with and without fish) (Suppl. Table 4). Sequences classified as non-metazoans and "unknown" were found in all samples. We found 10 taxa in common among zooplankton collected with fish and guts of both 526 fish species, 7 taxa unique to longfin smelt, 3 unique to Pacific herring, 13 unique to the zooplankton collected with fish, and 90 unique to the zooplankton collected with no fish. The 10 taxa found in all three fish-associated sample types included the copepods E. carolleeae, A.

529 robustus, A. americanus, Acartiella sinensis, and L. tetraspina, the cladocerans Daphnia sp. and

530 Ceriodaphnia laticaudata, the mysid Neomysis sp., an unidentified arthropod, and an

531 unidentified cyclopoid (Cyclopoida C). Variation in prey taxa was high among individual fish, 532 even among those collected in the same sample (Suppl. Figures 2 and 3). 
The prey taxa found only in longfin smelt guts included several fish species, namely $C$. pallasii (Pacific herring), Cottus asper (prickly sculpin), Gasterosteus aculeatus (threespine stickleback), and Acanthogobius flavimanus (yellowfin goby). Several prey taxa previously unreported in longfin smelt or herring diets included the copepods Osphranticum labronectum and Mesocyclops pehpeiensis, the insect Liposcelis rufa, the cnidarian Hydra oligactis, and the polychaete Dasybranchus sp. DNA identified as longfin smelt was found in herring guts; other unique prey included the barnacle Balanus crenatus, the bivalve Potamocorbula amurensis, the cladoceran Ceriodaphnia sp., the decapod Palaemon modestus and an unidentified insect.

\section{Relative Read Abundance (RRA)}

Individual variation in RRA was high among sequences from individual fish and zooplankton samples (Suppl. Figures 2 and 3). When aggregated across all fish within each sample set (tow), sequences classified as "unknown" made up $6.2-58.7 \%$ of the RRA in longfin smelt diets, $6.7-29.3 \%$ of the RRA in Pacific herring diets, and 5.3 - 19.5\% of the RRA in fishassociated zooplankton samples (Figure 4). A majority of metazoan sequence reads in guts of both fish species were from arthropods, including the copepods E. carolleeae, A. americanus, and A. robustus, with L. tetraspina important in Pacific herring.

The average RRA across all samples of each type shows which sequences were most abundant among all gut and zooplankton samples (Suppl. Table 4). In longfin smelt, $E$. carolleeae and $A$. americanus had the highest RRA values (33.0\% and $17.5 \%$, respectively) with

553 A. robustus as third most abundant (14.7\%). In Pacific herring, the three highest RRA values

554 were from E. carolleeae (24.6\%), L. tetraspina (20.3\%), and A. americanus (18.3\%). Sequences

555 classified as "unknown" contributed an overall RRA of 17.0\% in longfin smelt, 20.7\% in

556 herring, and $8.5 \%$ and $13.0 \%$ in fish-associated and no-fish zooplankton samples, respectively.

557 Longfin smelt consumed relatively little L. tetraspina (1.9\% RRA overall) even when they were

558 abundant in the zooplankton sample, while the mean RRA for L. tetraspina in Pacific herring 559 diets was 10-fold higher (20.3\% RRA).

560 The highest RRA values in fish-associated zooplankton samples were also from the 561 copepods E. carolleeae (30.1\%), A. americanus (14.9\%), L. tetraspina (13.1\%), and A. robustus $562(11.4 \%)$. The highest RRA values in no-fish zooplankton samples were from the same taxa, only 
with lower relative abundances. An additional 166 less-common taxa were detected only in zooplankton samples with RRA values from $<0.001 \%$ to $5.3 \%$ in the fish-associated zooplankton samples and $<0.001 \%$ to $3.1 \%$ RRA in no-fish zooplankton samples (Suppl. Table 4). copepods alone shows a higher-resolution view of the copepod prey of both larval fish species and highlights differences among samples (Figure 5). In general, presence of E. carolleeae, A. robustus, or $A$. americanus in the zooplankton sample usually coincided with presence and relatively high RRA in the diets of either fish. Other copepods in longfin diets at low RRA included A. sinensis, O. labronectum, P. forbesi, L. tetraspina, M. pehpeiensis, and Cyclopoida C (Suppl. Table 4).

Frequency of Occurrence (FO)

Copepods and fish were the most frequently detected prey in the longfin smelt larval diets (Figure 6). The prey with the highest frequency of occurrence in longfin smelt guts were identified as E. carolleeae (50.5\%) followed by A. americanus (29.9\%), A. robustus (19.6\%), and C. pallasii (18.6\%). Eurytemora carolleeae was also the most frequently detected prey in

580 larval herring guts (44.4\%) followed by L. tetraspina (30.2\%), A. americanus $(27.0 \%)$, and $S$. thaleichthys (12.7\%) (Suppl. Table 4). "Unknown” DNA was present in 55.7\% of longfin diets, $57.1 \%$ of herring diets, and all zooplankton samples.

Several taxa were present in all fish-associated zooplankton samples (100\% FO): $E$. carolleeae, P. forbesi, A. americanus, A. robustus, L. tetraspina, unidentified arthropods, and non-metazoans. Zooplankton samples not associated with fish samples had a similar representation of common taxa, except with a higher occurrence of unidentified insects with $76.9 \%$ FO, and lower FO for $P$. forbesi, $A$. sinensis, and A. robustus. The most common taxa

588 present only in fish-associated zooplankton samples and not found in the fish guts included $A$. vernalis (100\%), Sinocalanus doerrii (100\%), Harpacticoida A (100\%), Cyclopoida D (90\%),

590 and Bosmina longirostris (80\%) (Suppl. Table 4). The most common taxa found in no-fish

591 zooplankton samples and not found in fish diets included the Harpacticoida A (88.5\%), S. doerrii 
(92.3\%), Bosmina liederi (88.5\%), B. longirostris (84.6\%), and Skistodiaptomus pallidus

$593(84.6 \%)$.

\section{Comparison of Morphological Diet to dDNA}

Dietary DNA analysis of fish gut contents revealed a greater number of prey at a higher taxonomic resolution than morphological analysis in the subset of four longfin smelt diet samples used for this comparison (Figure 7). Taking into consideration differences in taxonomic resolution, all prey items identified by morphological analysis were also identified by molecular analysis with a few exceptions: rotifers, $S$. doerrii, and $T$. dextrilobatus, which were all present at

601 low FO in the guts used for morphological analysis but not detected in the guts used for

602 molecular analysis. For the two copepod species, there are few representatives for either species

603 in the database ( $\mathrm{n}=1$ for $S$. doerrii, $\mathrm{n}=5$ for $T$. dextrilobatus) so it is possible that the types

604 present in our study are genetically distinct from what is in the database and could have been 605 lumped into the "unknown" group as a result. Different species in the same genus were the best 606 hit based on BLASTn found in other samples from our dataset: S. tenellus and T. derjugini. The 607 result of these two being the top BLASTn hit likely resulted more from a lack of representatives

608 of the two local species in the database, or from a few misidentified organisms in the database 609 (see Discussion for more on this). The most frequently occurring species from morphological 610 analysis, E. carolleeae (88.5\% FO), was also the most frequently identified set of sequences 611 from dDNA analysis (59.2\% FO). Copepod groups reported morphologically as Unid.

612 Copepoda, Unid. Calanoida, or Unid. Cyclopoida correspond to copepod nauplii, most of which 613 would appear in the DNA database by species. As for the taxa that did not match well between 614 methods, any rotifers in the DNA assemblage were likely classified as "unknown" because they 615 are poorly represented in the database.

\section{Differential Abundance Analysis}

618 Differential abundance (DA) analysis of longfin smelt dDNA found 24 of the 27 total 619 prey types (including non-metazoans and unknowns) with DA values showing differences from zooplankton when using a false discovery rate of 5\% (Figure 8A). The range of DA included $C$.

621 asper at 22-fold higher in the diet than the zooplankton, to L. tetraspina at 0.001-fold of the 
622 value in the zooplankton. Of the prey types also found in zooplankton, H. oligactis was 2.9-fold

623 higher in the longfin smelt diet, M. pehpeiensis was 4.4-fold higher, D. magna was 4.2-fold

624 higher, non-metazoans were 0.04-fold lower, and "unknowns" were 0.02-fold lower. The highest

625 values of DA were in prey types not found in zooplankton samples, including three of the four

626 fishes, as well as L. rufa, L. hexactis, Dasybranchus sp., and Chydorus sp.

627 The DA analysis for Pacific herring dDNA found eight of the 18 total taxa with DA

628 values showing differences from zooplankton within the false discovery rate of 5\% (Figure 8B).

629 The range of DA included $S$. thaleichthys at 244-fold higher in the diet than in the zooplankton,

630 to $A$. robustus at 0.03 -fold the value in the zooplankton. Of the prey types also found in

631 zooplankton, E. carolleeae was 0.2-fold lower in the Pacific herring diet, non-metazoans were

632 0.38-fold lower, and "unknowns" were 0.13-fold lower. The highest values were also in the prey

633 types not found in the zooplankton samples, which include $S$. thaleichthys, $P$. modestus, $B$.

crenatus, and Unid. Insecta.

635

\section{$\underline{\text { Discussion }}$}

This study is the first to apply dDNA analysis to elucidate the diets of both longfin smelt and Pacific herring larvae. Our results show that both calanoid (E. carolleeae) and cyclopoid (A. americanus, A. robustus, and L. tetraspina in herring) copepods were the most common and abundant prey for these two species of larval fishes, and diets of these two species largely overlapped. The most abundant prey sequences (as RRA) among zooplankton samples were also

642 found in the fish guts, suggesting a general pattern of feeding on the most available prey, with 643 some exceptions, such as L. tetraspina, which was infrequently consumed by longfin smelt

644 despite its abundance. Twenty-five taxa were identified in the dDNA prey assemblage of the

645 longfin smelt, and 16 in the dDNA prey assemblage of the herring, including all prey taxa known

646 from prior morphological analysis in longfin smelt larvae and of prey taxa similar to those

647 previously described in Pacific herring larvae (Bollens \& Sanders 2004). While most prey taxa

648 were arthropods and previously known prey, we also found many taxa that were not previously

649 known to be consumed by these fish, some of which are soft-bodied species (e.g., the cnidarian

650 Hydra oligactis, and the polychaete Dasybranchus sp.). We also provide DNA identification for

651 species that are otherwise difficult to identify, including the copepod M. pehpeiensis, which was

652 previously only identified to genus in the SFE. The zooplankton metabarcoding dataset 
generated here is likely to harbor additional discoveries of this nature that have not yet been identified, and will continue to provide information about the pelagic, benthic, and wetlandassociated species present across the northern San Francisco Estuary.

\section{Common Prey}

As expected, arthropods were the dominant prey type for the longfin smelt larvae, notably the copepods E. carolleeae, A. americanus, and A. robustus. Previous studies reported Acanthocyclops sp. as important prey (Hobbs et al., 2006) and at least three congeneric species are present in the estuary including $A$. americanus, $A$. robustus, and $A$. vernalis, which have been confirmed in the current study. Our study found that A. americanus and A. robustus were both present and common in the diet and in the zooplankton samples. Acanthocyclops vernalis was present in $100 \%$ of fish-associated zooplankton samples but uncommon (0.67\% RRA; Suppl. Table 4) and was not consumed by either fish.

Arthropods were also the dominant prey type for Pacific herring larvae. Copepods were the most common and abundant prey sequences, with E. carolleeae and A. americanus among the most common copepod prey. Unlike longfin smelt, Pacific herring consumed moderate amounts of L. tetraspina. Given its greater abundance, L. tetraspina would be expected to play a role in the diets of fishes in the estuary. In fact, most other planktivorous fishes in the estuary do not commonly consume this species (Bryant and Arnold 2007; Slater and Baxter 2014), which is also supported by a prior study that found a low mortality rate in L. tetraspina (Kimmerer 2015).

\section{Uncommon Prey}

Many less-common prey taxa occurred in the diets of both fish species that could be useful in identifying life history characteristics or feeding behaviors of the fishes in situ. For example, the presence of Pacific herring DNA in the guts of many longfin smelt larvae (19\% FO) suggests that longfin smelt may have consumed herring eggs, which are adhesive and stick to substrates such as seagrass (Hay 1985). Pacific herring spawn every winter-spring in saline waters of the estuary (Watters et al., 2004); however, the extent of spawning further into the more brackish to fresh San Pablo and Suisun Bays has not been studied. The presence of herring DNA in longfin smelt diets from both Suisun and San Pablo Bays may indicate that longfin smelt larvae feed near substrates in these habitats, rather than in the open water. Moreover, a single 
684 herring egg (1.2 mm diameter, $125 \mu \mathrm{g} \mathrm{C} \mathrm{egg}^{-1}$; Torniainen \& Lehtiniemi 2008) contains about 38

685

686

687

688

689

690

691

692

693

694

695

696

697

698

699

700

701

702

703

704

705

706

707

708

709

710

711

712

713

714 times the organic carbon of a single adult E. carolleeae (3 $\mu \mathrm{g} \mathrm{C}$ copepod $^{-1}$; Pierson et al., 2016), making this a valuable supplement to the diets of the larval longfin smelt. Morphological diet analysis from the same field survey showed fish eggs in 6 of 551 longfin smelt gut samples, but eggs seen in morphological analysis were smaller than average-sized herring eggs and not identified to species (unpublished data) so may not have been herring eggs. Alternatively, herring DNA in the longfin smelt guts may have been from ingestion of herring feces or herring DNA present in detritus. Consumption of another fish species' DNA through detritus or feces would be more likely if the species are schooling together, but there is currently no evidence supporting mixed schooling between larvae of these two species in the SFE, aside from being collected in the same larval fish samples. Schooling behavior in other fishes like northern anchovy Engraulis mordax and Atlantic silversides Menidia sp. is established between 10-15 mm (standard length; Hunter 1981; Hunter \& Coyne 1982), so it is possible that the longfin smelt and Pacific herring were also forming schools during this study, given the dominant body sizes we sampled (Table 2). The detection of herring DNA in longfin smelt gut samples (or viceversa) could have been from cross-contamination during library preparation or sequencing, which is a problem that can be hard to identify (e.g., Ballenghien et al., 2017). However, no Pacific herring-DNA sequences were found in our negative extraction or PCR controls, so it seems unlikely that this sort of cross-contamination was prevalent enough in our study to explain our results.

Some of the less common prey taxa hint at the possibility of longfin smelt larvae feeding on detritus. Liposcelis rufa, identified in diets in two longfin smelt, is in a group of terrestrial insects, psocids, commonly known as book or bark lice. Its presence in the diet of longfin smelt suggests that these fish could have eaten detritus from terrestrial runoff or wind-blown debris. In morphological analysis of longfin smelt larval diets, unidentified plant material occurred in a small number of smelt diets (Figure 7), also suggesting that smelt may have fed on detrital aggregates or near seagrasses. Detritus and associated organisms can be an important source of food for many estuarine and neritic organisms, from zooplankton to fishes (Adams 1976; Harfmann et al., 2019; Heinle et al., 1977). Future work amplifying the dDNA with additional primers that target different types of organisms such as plants and microbes could be useful in identifying habitats that support longfin smelt. 
We found that 15 of the $25(60 \%)$ identified taxa in longfin guts were not a part of the herring diet, and most of the unique prey were also relatively uncommon (Figure 6). One of the

717 unique prey items in longfin smelt is also the first report of the copepod M. pehpeiensis in the

718 SFE. Seven unique prey taxa in the longfin smelt were also not found in the fish-associated zooplankton and occurred at a low FO and RRA in four or fewer of the individual longfin-diet samples. These unique prey taxa included three fishes: C. asper $(5.2 \% \mathrm{FO})$, G. aculeatus $(1.0 \%$ FO) and A. flavimanus (1.0\% FO). The presence of fish DNA in the longfin smelt larval diet most likely reflects occasional ingestion of the eggs of these species, or is evidence of the consumption of feces or detrital aggregates as discussed above for consumption of herring.

Six prey taxa in the Pacific herring diet were absent from longfin smelt. These included three which were likely ingested as meroplanktonic larvae: P. amurensis, B. crenatus, and $P$. modestus (Figure 6). Potamocorbula amurensis is an introduced clam that has decimated phytoplankton biomass throughout the SFE since its introduction in the 1980s (Alpine \& Cloern 1992; Carlton et al., 1990; Kimmerer et al., 1994; Nichols et al., 1990). Balanus crenatus is a widespread acorn barnacle in the North Pacific and North Atlantic that has planktonic larvae (WoRMS 2020). Palaemon modestus (syn. Exopalaemon modestus) was introduced around 2000 (Brown \& Hieb 2014) and has become a dominant component of the pelagic nekton assemblage in the freshwater areas of the Sacramento-San Joaquin Delta (Feyrer et al., 2017). of fishes: some fed much more frequently on cyclopoid copepods, while others fed primarily on calanoids or specialized on other prey such as chaetognaths (Sampey et al.2007). The difference in assemblages of unique prey between the two fish species suggests that herring may forage in different sub-habitats or may be better equipped to detect and capture meroplankton larvae and cyclopoids than longfin smelt, but further work would be required to test this hypothesis.

\section{Non-metazoans and Unknowns}

Non-metazoan taxa may be important prey for some fishes. In fact, the prior study of

742 Pacific herring larval diets in the Estuary found a high proportion of tintinnid ciliates in fishes

743 collected in the Central Bay (Bollens \& Sanders 2004). Other studies have found Tintinnopsis

744 spp. and Eutinnus neriticus to be the most abundant tintinnids throughout the SFE (Ambler et al., 
1985 ) but these were not found in our fish diets or zooplankton samples. Six taxa identified to a high level of confidence in the diets of the two fishes were lumped into the non-metazoan category, five of which were found in the longfin smelt. These included a mixotrophic flagellate Poterioochromonas malhamensis, an amoeba that is a known parasite of fish Cochliopodium minus (Dyková et al., 1998), a lichen Parmotrema stuppeum, a centric diatom Cyclostephanos sp., and a fungal plant pathogen Rhizoctonia solani. The Pacific herring guts contained the mixotrophic flagellate $P$. malhamensis as well as a centric diatom Skeletonema potamos. The zooplankton samples included a range of more common taxa including some phytoplankton (Melosira ambiqua, Thalassiosira pseudonana, Ditylum brightwellii), a wheat-associated fungus (Blumeria graminis), a soil fungus (Penicillium sclerotiorum), and an aquatic fungus (Tetracladium marchalianum). Melosira ambiqua was the most common non-metazoan, found in all no-fish zooplankton samples and in $67 \%$ of fish-associated zooplankton samples. However, since the sequencing primers were chosen to target metazoan prey of the larval fishes, amplification of the phytoplankton, protist, amoeboid, or fungal groups is likely incomplete. The representation of many common non-metazoans in the DNA database is also currently poor and it is likely that some "unknown" DNA in the fish diets and environment corresponds to known species in the estuary, like the tinitinnid ciliates noted above.

Many sequences could not be identified to a reliable level from comparison to existing genetic databases (55.7\% of ASVs, $12.4 \%$ of sequences), and further work is needed to determine what those prey are and whether they are important or informative prey items. A substantial number of the ASVs are likely to correspond to organisms that have not yet been identified and barcoded. For example, public mtCOI DNA sequences exist for only $61.2 \%$ of North American aquatic invertebrate genera (Curry et al., 2018).

\section{False Negatives}

In addition to the above-stated uncertainties in identification due to "unknown" DNA in the samples, there is also a chance for false negatives. In this study, whole guts were used for DNA extraction and blocking primers were used to reduce the amplification of predator DNA. In initial tests validating the efficacy of the blocking primers developed here, blocking primers reduced amplification of predator DNA in a longfin smelt sample from $85 \%$ of the total reads to $18 \%$ of the total reads and resulted in the amplification of more prey types in the sample with 
blocking primers, though at a low number of reads. A similar result occurred with the use of clupeid blocking primers; we observed both a reduction in amplification of herring DNA (from $72 \%$ herring DNA to $18 \%$ herring DNA) as well as amplification of a broader range of less abundant prey from the gut.

Despite the use of primers meant for amplification of diverse metazoan taxa in our study, sometimes called "universal" primers, mtCOI genes of some taxa are not amplified effectively. For example, the mtCOI DNA barcode is notoriously difficult to amplify in cyclopoid copepods (Cepeda et al., 2012) as well as in nematode worms (Creer et al., 2010), and some neogastropoda and cardiida (Zhang et al., 2018). By individually DNA barcoding morphologically identified copepods, we found that even the "universal" metabarcoding primers used here did not successfully amplify some of the cyclopoid taxa in our samples, including individuals tentatively identified as Acanthocyclops capillatus, Cyclops scutifer, and Eucyclops elegans (Suppl. Table 3). Therefore, the full diversity of cyclopoid copepods and other taxa noted above is likely underestimated by this study. Taxonomic gaps due to primer bias could be filled by sequencing additional marker genes (e.g., Clarke et al., 2017; Zhang et al., 2018).

It is possible that the mtCOI gene primers applied here combined with strict removal of amplicons outside of the target 313 bp may have removed additional novel items in the larval fish diets. There were $7597 \mathrm{ASVs}$ and $4.3 \times 10^{5}$ sequences that passed the stringent DADA2 quality checking but did not fit the target amplicon length (313 bp; Suppl. Figure 4). A majority of these ( $99 \%$ in both species) would have been classified as "unknown" in our study with the classification methods applied here: Some of these had low-level matches to mtCOI sequences (e.g., $<97 \%$ identity to a sequence in the database), while others had no matches at all to sequences in the database. Within the remaining sequences that did not equal the target length of $313 \mathrm{bp}$ and had a high-level ( $\geq 97 \%$ ID) match to a database sequence, a majority of these did not match the mtCOI gene. Within this subset of sequences that matched the mtCOI gene that were longer or shorter than $313 \mathrm{bp}$ we found sequences that were likely rotifers and diatoms in the zooplankton samples, and land plants and a flatworm in the diet samples. Unfortunately, in order to exclude the majority of non-target gene sequences, we knowingly excluded a relatively small number of possibly real mtCOI sequences. Amplification of non-target genes is not surprising: Collins et al., (2019) reported extensive mis-priming of multiple primer pairs developed for metabarcoding mtCOI. Despite the known limitations of primer binding sites for 
metabarcoding the mtCOI gene, the benefits of species-level identification and the growing database of barcoded organisms means this gene remains the best choice for community metabarcoding studies on metazoans (Andujar et al., 2018).

Fourteen percent of stomachs were empty in each of the two fish species we analyzed. This is similar to rates seen through morphological analysis of diets in juvenile longfin smelt which found $13-21 \%$ of stomachs to be empty in Suisun Marsh (Feyrer et al., 2003). In a dDNA study on diets of post-larval clupeids in Tosa Bay, Japan, the researchers observed no empty guts using primer sets targeting genes with lower taxonomic resolution (Hirai et al., 2017), but morphological analysis of clupeid larval diets can result in up to $70 \%$ of fishes with empty guts. (Morote et al., 2010). Given the strict sequence classification and size-based exclusion used in our study as noted above, it is likely that some of our empty stomachs contained low levels of unique prey: re-sequencing the fish guts targeting an additional gene (e.g. 18S rRNA) may help reveal a broader range of taxonomic groups in the fish diets.

\section{A Case of Mistaken Zooplankton Identities}

One of the more challenging aspects of eukaryotic metabarcoding is obtaining reliable identification of DNA sequences; this study is no exception. While we have made efforts to verify the DNA identity of the prey taxa described in this paper, some uncertainties remain. This remains to be solved, in part, because it can be hard to determine if the organism in the DNA database was properly identified before sequencing and thus, we end up having to make a judgement on the "real" DNA-based identity of an organism. For example, prior studies identified and described Tortanus dextrilobatus and Sinocalanus doerrii shortly after they were introduced to the upper Estuary (Orsi et al.1983; Orsi and Ohtsuka 1999). However, the best matches of our DNA sequences to the database for these genera were T. derjugini and S. tenellus, respectively for some ASVs, while T. dextrilobatus was the closest DNA match for other ASVs. Upon further inspection, alignment of DNA sequences from the Genbank database for all sequences corresponding to these four taxa suggests that a few misidentified organisms exist in the database, and that the original identifications (T. dextrilobatus and $S$. doerrii) are correct. Another currently unsolved mystery lies in our Neomysis sp. sequence. In addition to other mysid genera, there are two Neomysis species described in the SFE: Neomysis japonica and N. kadiakensis. We recovered six ASVs that were assigned with high confidence to Neomysis 
japonica in our initial analysis. Upon further inspection the highest BLASTn hit for all six ASVs was to $N$. japonica but only at $93.5 \%$ ID (Suppl. Table 5). At that level, the sequence was assigned using RDP classifier, but with that level of match with BLASTn it is likely that it is a mysid, but probably not $N$. japonica. For now, we assign it as Neomysis sp. but acknowledge that it could be one of the other mysids of the SFE not presently in the NCBI database (see Suppl. Table 5 for other special cases).

\section{Conclusions}

One aim of this study was to assess whether previously presumed food resources in the larval fish diets match what can be seen with a higher-resolution view of the prey field using dDNA, so that we can better assess the extent to which declining food resources are responsible for declines in fish abundance in the SFE. Overall, we found the prey assemblages in longfin smelt larvae and Pacific herring were similar and broadly reflect previous knowledge and concurrent morphological analysis of important prey (calanoid and cyclopoid copepods, primarily $E$. carolleeae at salinities in this study). In our study, both species relied on $E$. carolleeae, A. americanus, and A. robustus as dominant prey taxa in multiple samples. A key result of our study was that herring consumed L. tetraspina and other prey taxa that were not common prey for longfin smelt. These other prey taxa may provide an important source of food when larger calanoid copepods are not abundant, although other planktivorous fishes in the estuary also consume few L. tetraspina (Bouley \& Kimmerer, 2006; Bryant \& Arnold, 2007; Slater \& Baxter, 2014; Sullivan et al., 2016) despite its numerical dominance in low-salinity regions (Bollens et al., 2011).

We examined larvae of these two species primarily in shallow, nearshore habitats and wetland channels, in addition to the fish collected in deeper channels. Previous studies show shallow habitats support larval longfin smelt (Grimaldo et al., 2017; 2020; Lewis et al., 2019). Current and planned wetland restoration (California Wetlands Monitoring Workgroup 2020) may provide more foraging opportunities for both fish species in these critical habitats, through greater contact with protective shelter and greater zooplankton biomass in habitats not readily colonized by clams. The declines in fish abundance in the estuary as a whole (Sommer et al., 2007) likely reflect the more or less parallel declines in the abundance of appropriate food for 
868

869

870

871

872

873

874

875

876

877

878

879

880

881

882

883

884

885

886

887

888

889

890

891

892

893

894

895

896

897

their larvae, notably the larger calanoid copepod E. carolleeae, which declined after the introduction of $P$. amurensis (Kimmerer et al., 1994).

In general, there were a greater number of species (ASV) sequenced from zooplankton samples than the fish diets. There was high variability in the prey taxa in individual fish guts (Suppl. Figure 2) and how much prey DNA was present. This may be a result of some of the fishes exploiting areas of patchy food availability and thus having different prey species in their diets. Larval fishes that exploit patches of concentrated food, such as in surface slicks in the open ocean, have higher survival likelihood and better body conditions than fishes found outside of concentrated food patches (Gove et al., 2019; Hunter 1981). Fish larvae are also visual feeders, and feeding is usually confined to the daylight hours due to limited visual abilities during the first few weeks of life; a prey item therefore has to be relatively nearby to be detected, and does not have to be motile (Hunter 1981). Feeding in a turbid estuary may present larval fishes with additional challenges but this turbid environment may also may provide the larval fishes with protection from visual predators (Boehlert \& Morgan 1985; Sirois \& Dodson 2000).

Larval fish growth rates depend strongly on food supply (Pepin et al., 2014). laboratory growth rates of Larval plaice and Atlantic herring reached maxima at food densities (copepod and Artemia nauplii) of $\sim 500$ prey $\mathrm{L}^{-1}$ in larval plaice and Atlantic herring in the laboratory (Kiorboe \& Munk 1986; Wyatt 1972). Other clupeid species' larvae also survive better at prey densities of up to $1000-4000$ copepods $\mathrm{L}^{-1}$ in the laboratory (reviewed in Hunter 1981). In monitoring data taken in our sampling regions during springs of recent wet years $(2006,2011$, this study 2017; “20-mm” survey, Dege and Brown 2004), calanoid copepod abundance (mostly juveniles and adults; nauplii undersampled) had a median of $\sim 6$ and rarely reached 10 copepods $\mathrm{L}^{-1}$, while the cyclopoids (mostly juveniles and adults; nauplii undersampled) reached about 1 copepod $\mathrm{L}^{-1}$. Thus, prey abundances in the northern SFE are one to two orders of magnitude lower than what seems to be required for high growth rates and high survival of most fish larvae. Our study also found that not all copepod prey are considered equally important to these fishes, as longfin smelt do not consume the abundant L. tetraspina, while Pacific herring seem to feed more generally. These results paint a disheartening picture of the foodweb support available to larval fishes in this region of the SFE and echo the need for ongoing restoration efforts to help enhance foodweb resources and protective habitat for fishes in the estuary. 
Our findings illustrate the power of DNA-based methods to reveal feeding patterns and

899 novel zooplankton diversity undetectable through complementary morphological analysis. We

900 revealed larval fish feeding on two of the three Acanthocyclops spp., which are otherwise

901 difficult to identify, found several fish species' DNA in the larval fish diets, and identified larval

902 meroplankton to the species level in the diets of the herring. These are just a few examples of the

903 power of DNA-sequencing methods in studies of aquatic food web interactions. We also found at

904 least one aquatic species not previously described in the SFE, the copepod M. pehpeiensis. This

905 work provides a baseline for the genetic diversity of zooplankton in regions of San Pablo Bay

906 and Suisun Bay in the northern SFE as of 2017, and a snapshot of the diets of two larval fishes

907 during a wet year in 2017. Future research would benefit from targeted DNA barcoding of

908 additional potential prey taxa that has poor representation in the NCBI database, such as

909 meroplankton larvae and local aquatic-associated insects, and from deeper studies into the DNA

910 recovered from unidentified arthropods, insects, and “unknown” DNA sequences.

911 
$\underline{\text { References }}$

914

915

916

917

918

919

920

921

922

923

924

925

926

927

928

929

930

931

932

933

934

935

936

937

938

939

940

941

942

943

944

945

946

947

948

Adams, S. M. (1976). Feeding Ecology of Eelgrass Fish Communities. Transactions of the American Fisheries Society, 105(4), 514-519.

Albaina, A., Aguirre, M., Abad, D., Santos, M., \& Estonba, A. (2016). 18S rRNA V9 metabarcoding for diet characterization: A critical evaluation with two sympatric zooplanktivorous fish species. Ecology and Evolution, 6(6), 1809-1824. https://doi.org/10.1002/ece3.1986

Alekseev, V. R., \& Souissi, A. (2011). A new species within the Eurytemora affinis complex (Copepoda: Calanoida) from the Atlantic Coast of USA, with observations on eight morphologically different European populations. Zootaxa, 2767, 41-56.

Alpine, A. E., \& Cloern, J. E. (1992). Trophic interactions and direct physical effects control phytoplankton biomass and production in an estuary. Limnology and Oceanography, 37(5), 946-955. https://doi.org/10.4319/10.1992.37.5.0946

Ambler, J. W., Cloern, E., \& Hutchinson, A. (1985). Seasonal cycles of zooplankton from San Francisco Bay. Hydrobiologia, 129, 177-197.

Andújar, C., Arribas, P., Gray, C., Bruce, C., Woodward, G., Yu, D. W., \& Vogler, A. P. (2018). Metabarcoding of freshwater invertebrates to detect the effects of a pesticide spill. Molecular Ecology, 27(1), 146-166. https://doi.org/10.1111/mec.14410

Baker, R., Buckland, A., \& Sheaves, M. (2014). Fish gut content analysis: Robust measures of diet composition. Fish and Fisheries, 15(1), 170-177. https://doi.org/10.1111/faf.12026

Ballenghien, M., Faivre, N., \& Galtier, N. (2017). Patterns of cross-contamination in a multispecies population genomic project: Detection, quantification, impact, and solutions. BMC Biology, 15(1), 25. https://doi.org/10.1186/s12915-017-0366-6

Baxter, R., Breuer, R., Brown, L., Conrad, L., Feyrer, F., Fong, S., Gehrts, K., Grimaldo, L., Herbold, B., Hrodey, P., Mueller-Solger, A., Sommer, T., \& Souza, K. (2010). 2010 Pelagic Organism Decline Work Plan and Synthesis of Results. Interagency Ecological Program for the San Francisco Estuary. https://water.ca.gov/LegacyFiles/iep/docs/FinalPOD2010Workplan12610.pdf

Beck, M. W., Heck, K. L., Able, K. W., Childers, D. L., Eggleston, D. B., Gillanders, B. M., Halpern, B., Hays, C. G., Hoshino, K., Minello, T. J., Orth, R. J., Sheridan, P. F., \& Weinstein, M. P. (2001). The Identification, Conservation, and Management of Estuarine and Marine Nurseries for Fish and Invertebrates. BioScience, 51(8), 633. https://doi.org/10.1641/0006-3568(2001)051[0633:TICAMO]2.0.CO;2

Bennett, W. A., \& Moyle, P. B. (1996). Where have all the fishes gone? Interactive factors producing fish declines in the Sacramento-San Joaquin Estuary. In J. T. Hollibaugh (Ed.), San Francisco Bay: The Ecosystem (pp. 519-542). AAAS. 
Blaxter, J. H. S. (1965). Feeding of herring larvae and their ecology in relation to feeding. California Cooperative Oceanic Fisheries Investigations Report, 10, 79-88.

Boehlert, G. W., \& Morgan, J. B. (1985). Turbidity enhances feeding abilities of larval Pacific herring, Clupea harengus pallasi. Hydrobiologia, 123, 161-170.

Boehlert, G. W., \& Mundy, B. C. (1988). Roles of Behavioral and Physical Factors in Larval and Juvenile Fish Recruitment to Estuarine Nursery Areas. American Fisheries Society Symposium, 3(5), 17.

Bollens, S. M., Breckenridge, J. K., Vanden Hooff, R. C., \& Cordell, J. R. (2011). Mesozooplankton of the lower San Francisco Estuary: Spatio-temporal patterns, ENSO effects and the prevalence of non-indigenous species. Journal of Plankton Research, 33(9), 1358-1377. https://doi.org/10.1093/plankt/fbr034

Bollens, S. M., \& Sanders, A. M. (2004). Ecology of Larval Pacific Herring in the San Francisco Estuary: Seasonal and Interannual Abundance, Distribution, Diet, and Condition. In F. Feyrer, L. R. Brown, R. L. Brown, \& J. J. Orsi (Eds.), Early Life History of Fishes in the San Francisco Estuary and Watershed (pp. 15-35). American Fisheries Society.

Bouley, P., \& Kimmerer, W. (2006). Ecology of a highly abundant, introduced cyclopoid copepod in a temperate estuary. Marine Ecology Progress Series, 324, 219-228. https://doi.org/10.3354/meps324219

Bowers, A. B., \& Williamson, D. I. (1951). Food of larval and early post-larval stages of autumn-spawned herring in Manx waters. Report of the Marine Biological Station at Port Erin, 63, 17-26.

Bowser, A. K., Diamond, A. W., \& Addison, J. A. (2013). From puffins to plankton: A DNAbased analysis of a seabird food chain in the northern Gulf of Maine. PLoS ONE, 8, e83152. https://doi.org/10.1371/journal.pone.0083152

Bronner, I. F., Quail, M. A., Turner, D. J., \& Swerdlow, H. (2013). Improved Protocols for Illumina Sequencing: Improved Protocols for Illumina Sequencing. In J. L. Haines, B. R. Korf, C. C. Morton, C. E. Seidman, J. G. Seidman, \& D. R. Smith (Eds.), Current Protocols in Human Genetics (p. 18.2.1-18.2.42). John Wiley \& Sons, Inc. https://doi.org/10.1002/0471142905.hg1802s 79

Brown, T., \& Hieb, K. A. (2014). Status of the Siberian Prawn, Exopalaemon modestus, in the San Francisco Estuary. San Francisco Estuary and Watershed Science, 12(1). https://doi.org/10.15447/sfews.2014v12iss1art4

Brown, Larry R., Kimmerer, W., Conrad, J. L., Lesmeister, S., \& Mueller-Solger, A. (2016). Food Webs of the Delta, Suisun Bay, and Suisun Marsh: An Update on Current Understanding and Possibilities for Management. San Francisco Estuary and Watershed Science, 14(3). https://doi.org/10.15447/sfews.2016v14iss3art4 
985 986

987

988

989

990

991

992

993

994

995

996

997

998

999

1000

1001

1002

1003

1004

1005

1006

1007

1008

1009

1010

1011

1012

1013

1014

1015

1016

1017

1018

1019

Bryant, M. E., \& Arnold, J. D. (2007). Diets of age-0 striped bass in the San Francisco Estuary, 1973-2002. California Fish and Game, 93, 1-22.

Bucklin, A. (2000). Methods for population genetic analysis of zooplankton. In R. Harris, P. Wiebe, J. Lenz, H. R. Skjoldal, \& M. Huntley (Eds.), ICES Zooplankton Methodology Manual (pp. 533-570). Academic Press.

California Wetlands Monitoring Workgroup (CWMW). "Habitat Projects." EcoAtlas. Accessed 24 August 2020. https://www.ecoatlas.org/regions/ecoregion/bay-delta

Callahan, B. J., McMurdie, P. J., Rosen, M. J., Han, A. W., Johnson, A. J. A., \& Holmes, S. P. (2016). DADA2: High-resolution sample inference from Illumina amplicon data. Nature Methods, 13(7), 581-583. https://doi.org/10.1038/nmeth.3869

Carlton, J. T., Thompson, J. K., Schemel, L. E., \& Nichols, F. H. (1990). Remarkable invasion of San Francisco Bay (California, USA) by the Asian clam Potamocorbula amurensis .1. Introduction and dispersal. Marine Ecology Progress Series, 66(1-2), 81-94.

Cepeda, G. D., Blanco-Bercial, L., Bucklin, A., Berón, C. M., \& Viñas, M. D. (2012). Molecular Systematic of Three Species of Oithona (Copepoda, Cyclopoida) from the Atlantic Ocean: Comparative Analysis Using 28S rDNA. PLoS ONE, 7(4), e35861. https://doi.org/10.1371/journal.pone.0035861

Chigbu, P., \& Sibley, T. H. (1994). Diet and growth of longfin smelt and juvenile sockeye salmon in Lake Washington. In A. Sladeckova (Ed.), International Association of Theoretical and Applied Limnology-Proceedings, Vol 25, Pt 4 (pp. 2086-2091). :/WOS:A1994BC18H00009

Choi, Hee Chan, Park, Joo Myun, Youn, Suk Hyun, \& Huh, Sung-Hoi. (2015). Feeding habits of larval Clupea pallasii from the Nakdong River Estuary, Korea. Korean Journal of Fisheries and Aquatic Sciences, 48(4), 498-506. https://doi.org/10.5657/KFAS.2015.0498

Clarke, L. J., Beard, J. M., Swadling, K. M., \& Deagle, B. E. (2017). Effect of marker choice and thermal cycling protocol on zooplankton DNA metabarcoding studies. Ecology and Evolution, 7(3), 873-883. https://doi.org/10.1002/ece3.2667

Collins, R. A., Bakker, J., Wangensteen, O. S., Soto, A. Z., Corrigan, L., Sims, D. W., Genner, M. J., \& Mariani, S. (2019). Non-specific amplification compromises environmental DNA metabarcoding with COI. Methods in Ecology and Evolution, 10(11), 1985-2001. https://doi.org/10.1111/2041-210X.13276

Craig, C., Kimmerer, W. J., \& Cohen, C. S. (2014). A DNA-based method for investigating feeding by copepod nauplii. Journal of Plankton Research, 36(1), 271-275. https://doi.org/10.1093/plankt/fbt104 
Creer, S., Fonseca, V. G., Porazinska, D. L., Giblin-Davis, R. M., Sung, W., Power, D. M., Packer, M., Carvalho, G. R., Blaxter, M. L., Lambshead, P. J. D., \& Thomas, W. K. (2010). Ultrasequencing of the meiofaunal biosphere: Practice, pitfalls and promises. Molecular Ecology, 19, 4-20. https://doi.org/10.1111/j.1365-294X.2009.04473.x

Curry, C. J., Gibson, J. F., Shokralla, S., Hajibabaei, M., \& Baird, D. J. (2018). Identifying North American freshwater invertebrates using DNA barcodes: Are existing COI sequence libraries fit for purpose? Freshwater Science, 37(1), 178-189. https://doi.org/10.1086/696613

Cury, P., Bakun, A., Crawford, R. J., Jarre, A., Quinones, R. A., Shannon, L. J., \& Verheye, H. M. (2000). Small pelagics in upwelling systems: Patterns of interaction and structural changes in "wasp-waist" ecosystems. ICES Journal of Marine Science, 57(3), 603-618.

Cury, P. M., Boyd, I. L., Bonhommeau, S., Anker-Nilssen, T., Crawford, R. J. M., Furness, R. W., Mills, J. A., Murphy, E. J., Osterblom, H., Paleczny, M., Piatt, J. F., Roux, J.-P., Shannon, L., \& Sydeman, W. J. (2011). Global Seabird Response to Forage Fish Depletion-One-Third for the Birds. Science, 334(6063), 1703-1706. https://doi.org/10.1126/science.1212928

Deagle, B. E., Thomas, A. C., McInnes, J. C., Clarke, L. J., Vesterinen, E. J., Clare, E. L., Kartzinel, T. R., \& Eveson, J. P. (2019). Counting with DNA in metabarcoding studies: How should we convert sequence reads to dietary data? Molecular Ecology, 28(2), 391406. https://doi.org/10.1111/mec.14734

Dege, M., and L. R. Brown. 2004. Effect of outflow on spring and summertime distribution and abundance of larval and juvenile fishes in the upper San Francisco Estuary. Pages 49-65 in F. Feyrer, L. R. Brown, R. L. Brown, and J. J. Orsi, editors. Early Life History of Fishes in the San Francisco Estuary and Watershed. American Fisheries Society, Bethesda MD.

Dyková, I., Lom, J., \& Machácková, B. (1998). Cochliopodium minus, a scale-bearing amoeba isolated from organs of perch Perca fluviatilis. Diseases of Aquatic Organisms, 34(3), 205-210.

Evermann, B. W., \& Lee, E. (1906). Postlarval Development and Diet of the Largescale Sucker. Bull. US Bur. Fish, 26, 219-360.

Feinsinger, P., Spears, E. E., \& Poole, R. W. (1981). A Simple Measure of Niche Breadth. Ecology, 62(1), 27-32. https://doi.org/10.2307/1936664

Feyrer, F., Herbold, B., Matern, S. A., \& Moyle, P. B. (2003). Dietary shifts in a stressed fish assemblage: Consequences of a bivalve invasion in the San Francisco Estuary. Environmental Biology of Fishes, 67, 277-288. 
1055

1056

1057

1058

1059

1060

1061

1062

1063

1064

1065

1066

1067

1068

1069

1070

1071

1072

1073

1074

1075

1076

1077

1078

1079

1080

1081

1082

1083

1084

1085

1086

1087

1088

1089

1090

1091

Feyrer, Frederick, Slater, S. B., Portz, D. E., Odom, D., Morgan-King, T., \& Brown, L. R. (2017). Pelagic Nekton Abundance and Distribution in the Northern Sacramento-San Joaquin Delta, California. Transactions of the American Fisheries Society, 146(1), 128135. https://doi.org/10.1080/00028487.2016.1243577

Folmer, O., Black, M., Hoeh, W., Lutz, R., \& Vrijenhoek, R. (1994). DNA primers for amplification of mitochondrial cytochrome c oxidase subunit I from diverse metazoan invertebrates. Molecular Marine Biology and Biotechnology, 3, 294-299.

Garwood, R. S. (2017). Historic and contemporary distribution of Longfin Smelt (Spirinchus thaleichthys) along the California coast. CALIFORNIA FISH AND GAME, 103(3), 96117.

Geller, J., Meyer, C., Parker, M., \& Hawk, H. (2013). Redesign of PCR primers for mitochondrial cytochrome $c$ oxidase subunit I for marine invertebrates and application in all-taxa biotic surveys. Molecular Ecology Resources, 13(5), 851-861. https://doi.org/10.1111/1755-0998.12138

Gove, J. M., Whitney, J. L., McManus, M. A., Lecky, J., Carvalho, F. C., Lynch, J. M., Li, J., Neubauer, P., Smith, K. A., Phipps, J. E., Kobayashi, D. R., Balagso, K. B., Contreras, E. A., Manuel, M. E., Merrifield, M. A., Polovina, J. J., Asner, G. P., Maynard, J. A., \& Williams, G. J. (2019). Prey-size plastics are invading larval fish nurseries. Proceedings of the National Academy of Sciences, 116(48), 24143-24149.

https://doi.org/10.1073/pnas.1907496116

Grimaldo, L., Burns, J., Miller, R. E., Kalmbach, A., Smith, A., Hassrick, J., \& Brennan, C. (2020). Forage Fish Larvae Distribution and Habitat Use During Contrasting Years of Low and High Freshwater Flow in the San Francisco Estuary. San Francisco Estuary \& Watershed Science, 18(3), 20. https://doi.org/10.15447/sfews.2020v18iss3art5

Grimaldo, L., Feyrer, F., Burns, J., \& Maniscalco, D. (2017). Sampling Uncharted Waters: Examining Rearing Habitat of Larval Longfin Smelt (Spirinchus thaleichthys) in the Upper San Francisco Estuary. Estuaries and Coasts, 40(6), 1771-1784. https://doi.org/10.1007/s12237-017-0255-9

Hammock, B. G., Hobbs, J. A., Slater, S. B., Acuña, S., \& Teh, S. J. (2015). Contaminant and food limitation stress in an endangered estuarine fish. Science of the Total Environment, $532,316-326$.

Harfmann, J., Kurobe, T., Bergamaschi, B., Teh, S., \& Hernes, P. (2019). Plant detritus is selectively consumed by estuarine copepods and can augment their survival. Scientific Reports, 9(1), 9076. https://doi.org/10.1038/s41598-019-45503-6

Hay, D. E. (1985). Reproductive Biology of Pacific Herring ( Clupea harengus pallasi). Canadian Journal of Fisheries and Aquatic Sciences, 42(S1), s111-s126. https://doi.org/10.1139/f85-267 
1092

1093

1094

1095

1096

1097

1098

1099

1100

1101

1102

1103

1104

1105

1106

1107

1108

1109

1110

1111

1112

1113

1114

1115

1116

1117

1118

1119

1120

1121

1122

1123

1124

1125

1126

1127

Heinle, D. R., Harris, R. P., Ustach, J. F., \& Flemer, D. A. (1977). Detritus as food for estuarine copepods. Marine Biology, 40, 341-353.

Hirai, J., Hidaka, K., Nagai, S., \& Ichikawa, T. (2017). Molecular-based diet analysis of the early post-larvae of Japanese sardine Sardinops melanostictus and Pacific round herring Etrumeus teres. Marine Ecology Progress Series, 564, 99-113. https://doi.org/10.3354/meps12008

Ho, T. W., Hwang, J.-S., Cheung, M. K., Kwan, H. S., \& Wong, C. K. (2017). DNA-based study of the diet of the marine calanoid copepod Calanus sinicus. Journal of Experimental Marine Biology and Ecology, 494, 1-9. https://doi.org/10.1016/j.jembe.2017.04.004

Hobbs, J. A., Bennett, W. A., \& Burton, J. E. (2006). Assessing nursery habitat quality for native smelts (Osmeridae) in the low-salinity zone of the San Francisco estuary. Journal of Fish Biology, 69(3), 907-922. https://doi.org/10.1111/j.1095-8649.2006.01176.x

Hunt Jr, G. L., Stabeno, P., Walters, G., Sinclair, E., Brodeur, R. D., Napp, J. M., \& Bond, N. A. (2002). Climate change and control of the southeastern Bering Sea pelagic ecosystem. Deep Sea Research Part II: Topical Studies in Oceanography, 49(26), 5821-5853. https://doi.org/10.1016/S0967-0645(02)00321-1

Hunt von Herbing, I., \& Gallager, S. M. (2000). Foraging behavior in early Atlantic cod larvae ( Gadus morhua ) feeding on a protozoan ( Balanion sp.) and a copepod nauplius ( Pseudodiaptomus sp.). Marine Biology, 136(3), 591-602. https://doi.org/10.1007/s002270050719

Hunter, J. R. (1981). Feeding ecology and predation of marine fish larvae. In R. Lasker (Ed.), Marine fish larvae (pp. 33-77). University of Washington Press.

Hunter, J. R., \& Coyne, K. M. (1982). The onset of schooling in northern anchovy larvae, Engraulis mordax. CalCOFI Reports, 23, 246-251.

Hynes, H. B. N. (1950). The food of fresh-water sticklebacks (Gasterosteus aculeatus and Pygosteus pungitius), with a review of methods used in studies of the food of fishes. The Journal of Animal Ecology, 36-58.

Hyslop, E. J. (1980). Stomach contents analysis-A review of methods and their application. Journal of Fish Biology, 17(4), 411-429. https://doi.org/10.1111/j.10958649.1980.tb02775.x

Keppeler, F. W., Lanés, L. E. K., Rolon, A. S., Stenert, C., Lehmann, P., Reichard, M., \& Maltchik, L. (2015). The morphology-diet relationship and its role in the coexistence of two species of annual fishes. Ecology of Freshwater Fish, 24(1), 77-90. https://doi.org/10.1111/eff.12127

Kimmerer, W. J. (2002). Effects of freshwater flow on abundance of estuarine organisms: Physical effects or trophic linkages? Marine Ecology Progress Series, 243, 39-55. 
Kimmerer, W. J. (2006). Response of anchovies dampens effects of the invasive bivalve Corbula amurensis on the San Francisco Estuary foodweb. Marine Ecology Progress Series, 324, 207-218. https://doi.org/10.3354/meps324207

Kimmerer, W. J. (2008). Losses of Sacramento River Chinook salmon and delta smelt to entrainment in water diversions in the Sacramento-San Joaquin Delta. San Francisco Estuary and Watershed Science, 6(2), Article 2.

Kimmerer, W. J. (2015). Mortality estimates of stage-structured populations must include uncertainty in stage duration and relative abundance. Journal of Plankton Research, 37(5), 939-952. https://doi.org/10.1093/plankt/fbv073

Kimmerer, W. J., Gartside, E., \& Orsi, J. J. (1994). Predation by an introduced clam as the likely cause of substantial declines in zooplankton of San Francisco Bay. Marine Ecology Progress Series, 113(1/2), 81-93. JSTOR.

Kimmerer, W. J., Gross, E. S., \& MacWilliams, M. L. (2009). Is the response of estuarine nekton to freshwater flow in the San Francisco Estuary explained by variation in habitat volume? Estuaries and Coasts, 32(2), 375-389. https://doi.org/10.1007/s12237-008-9124-X

Kimmerer, W. J., \& Orsi, J. J. (1996). Causes of long-term declines in zooplankton in the San Francisco Bay estuary since 1987. In J. T. Hollibaugh (Ed.), San Francisco Bay: The Ecosystem (pp. 403-424). AAAS.

Kimmerer, W. J., and J. K. Thompson. 2014. Phytoplankton growth balanced by clam and zooplankton grazing and net transport into the low-salinity zone of the San Francisco Estuary. Estuaries and Coasts 37(5):1202-1218.

Kiørboe, T., \& Munk, P. (1986). Feeding and growth of larval herring, Clupea harengus, in relation to density of copepod nauplii. Environmental Biology of Fishes, 17(2), 133-139.

Kurata, H. (1959). Preliminary report on the rearing of the herring larvae. Bull. Hokkaido Reg. Fish. Res. Lab., 20, 117-138.

Leggett, W. C., \& Deblois, E. (1994). Recruitment in marine fishes: Is it regulated by starvation and predation in the egg and larval stages? Netherlands Journal of Sea Research, 32(2), 119-134. https://doi.org/10.1016/0077-7579(94)90036-1

Leray, M., Alldredge, A. L., Yang, J. Y., Meyer, C. P., Holbrook, S. J., Schmitt, R. J., Knowlton, N., \& Brooks, A. J. (2019). Dietary partitioning promotes the coexistence of planktivorous species on coral reefs. Molecular Ecology, mec. 15090. https://doi.org/10.1111/mec. 15090

Leray, M., Yang, J. Y., Meyer, C. P., Mills, S. C., Agudelo, N., Ranwez, V., Boehm, J. T., \& Machida, R. J. (2013). A new versatile primer set targeting a short fragment of the mitochondrial COI region for metabarcoding metazoan diversity: Application for 
characterizing coral reef fish gut contents. Frontiers in Zoology, 10(1), 34. https://doi.org/10.1186/1742-9994-10-34

Lewis, L. S., Willmes, M., Barros, A., Crain, P. K., \& Hobbs, J. A. (2020). Newly discovered spawning and recruitment of threatened Longfin Smelt in restored and underexplored tidal wetlands. Ecology, 101(1), e02868.

Llopiz, J. K. (2013). Latitudinal and taxonomic patterns in the feeding ecologies of fish larvae: A literature synthesis. Journal of Marine Systems, 109-110, 69-77. https://doi.org/10.1016/j.jmarsys.2012.05.002

Machida, R. J., Leray, M., Ho, S.-L., \& Knowlton, N. (2017). Metazoan mitochondrial gene sequence reference datasets for taxonomic assignment of environmental samples. Scientific Data, 4, 170027. https://doi.org/10.1038/sdata.2017.27

McMurdie, P. J., \& Holmes, S. (2013). phyloseq: An R package for reproducible interactive analysis and graphics of microbiome census data. PLoS ONE, 8(4), e61217.

Montagnes, D. J. S., Dower, J. F., \& Figueiredo, G. M. (2010). The ProtozooplanktonIchthyoplankton Trophic Link: An Overlooked Aspect of Aquatic Food Webs. Journal of Eukaryotic Microbiology. https://doi.org/10.1111/j.1550-7408.2010.00476.x

Morote, E., Olivar, M. P., Villate, F., \& Uriarte, I. (2010). A comparison of anchovy (Engraulis encrasicolus) and sardine (Sardina pilchardus) larvae feeding in the Northwest Mediterranean: Influence of prey availability and ontogeny. ICES Journal of Marine Science, 67(5), 897-908. https://doi.org/10.1093/icesjms/fsp302

Moyle, P. B., Brown, L., Durand, J., \& Hobbs, J. (2016). Delta Smelt: Life History and Decline of a Once-Abundant Species in the San Francisco Estuary. San Francisco Estuary and Watershed Science, 14(2). https://doi.org/10.15447/sfews.2016v14iss2art6

Moyle, P. B., Lund, J. R., Bennett, W. A., \& Fleenor, W. E. (2010). Habitat Variability and Complexity in the Upper San Francisco Estuary. San Francisco Estuary and Watershed Science, 8 .

Nichols, F. H., Thompson, J. K., \& Schemel, L. E. (1990). Remarkable invasion of San Francisco Bay (California, USA) by the Asian clam Potamocorbula amurensis. II. Displacement oi a former community. Marine Ecology-Progress Series, 66, 95-101.

1192 Nobriga, M. L., \& Rosenfield, J. A. (2016). Population Dynamics of an Estuarine Forage Fish: 
Okamoto, D. K., Schmitt, R. J., Holbrook, S. J., \& Reed, D. C. (2012). Fluctuations in food supply drive recruitment variation in a marine fish. Proceedings of the Royal Society B: Biological Sciences, 279(1747), 4542-4550. https://doi.org/10.1098/rspb.2012.1862

Oksanen, J., Blanchet, F. G., Friendly, M., Kindt, R., Legendre, P., McGlinn, D., Minchin, P. R., O’Hara, R. B., Simpson, G. L., Solymos, P., Stevens, M. H. H., Szoecs, E., \& Wagner, H. (2019). Vegan: Community Ecology Package (2.5-6) [Computer software].

O’Rorke, R., Lavery, S., Chow, S., Takeyama, H., Tsai, P., Beckley, L. E., Thompson, P. A., Waite, A. M., \& Jeffs, A. G. (2012). Determining the Diet of Larvae of Western Rock Lobster (Panulirus cygnus) Using High-Throughput DNA Sequencing Techniques. PLoS ONE, 7(8), e42757. https://doi.org/10.1371/journal.pone.0042757

Orsi, J. J., Bowman, T. E., Marreli, D. C., \& Hutchinson, A. (1983). Recent introduction of the planktonic calanoid copepod Sinocalanus doerrii (Centropagidae) from mainland China to the Sacramento-San Joaquin Estuary of California. Journal of Plankton Research, 5, $357-375$.

Orsi, J. J., \& Ohtsuka, S. (1999). Introduction of the Asian copepods Acartiella sinensis, Tortanus dextrilobatus (Copepoda: Calanoida), and Limnoithona tetraspina (Copepoda: Cyclopoida) to the San Francisco Estuary, California, USA. Plankton Biology and Ecology, 46, 128-131.

Pepin, P. (2004). Early life history studies of prey-predator interactions: Quantifying the stochastic individual responses to environmental variability. Canadian Journal of Fisheries and Aquatic Science, 61, 659-671. https://doi.org/10.1139/F04-078

Pepin, P., Robert, D., Bouchard, C., Dower, J. F., Falardeau, M., Fortier, L., Jenkins, G. P., Leclerc, V., Levesque, K., Llopiz, J. K., Meekan, M. G., Murphy, H. M., Ringuette, M., Sirois, P., \& Sponaugle, S. (2014). Once upon a larva: Revisiting the relationship between feeding success and growth in fish larvae. ICES Journal of Marine Science, 72(2), 359-373. https://doi.org/10.1093/icesjms/fsu201

Pierson, J. J., Kimmel, D. G., \& Roman, M. R. (2016). Temperature Impacts on Eurytemora carolleeae Size and Vital Rates in the Upper Chesapeake Bay in Winter. Estuaries and Coasts, 39(4), 1122-1132. https://doi.org/10.1007/s12237-015-0063-z

Pompanon, F., Deagle, B. E., Symondson, W. O. C., Brown, D. S., Jarman, S. N., \& Taberlet, P. (2012). Who is eating what: Diet assessment using next generation sequencing: NGS DIET ANALYSIS. Molecular Ecology, 21(8), 1931-1950. https://doi.org/10.1111/j.1365-294X.2011.05403.X

R Core Team. (2019). R: A Language and Environment for Statistical Computing. R Foundation for Statistical Computing. https://www.R-project.org/ 
Reitan, K. I., Natvik, C. M., \& Vadstein, O. (1998). Drinking rate, uptake of bacteria and microalgae in turbot larvae. Journal of Fish Biology, 53(6), 1145-1154. https://doi.org/10.1111/j.1095-8649.1998.tb00238.x

Robinson, M. D., McCarthy, D. J., \& Smyth, G. K. (2010). edgeR: A Bioconductor package for differential expression analysis of digital gene expression data. Bioinformatics, 26(1), 139-140. https://doi.org/10.1093/bioinformatics/btp616

Rohland, N., \& Reich, D. (2012). Cost-effective, high-throughput DNA sequencing libraries for multiplexed target capture. Genome Research, 22(5), 939-946.

Rose, K. A., Kimmerer, W. J., Edwards, K. P., \& Bennett, W. A. (2013). Individual-based modeling of delta smelt population dynamics in the upper San Francisco Estuary. I. Model Description and Baseline Results. Transactions of the American Fisheries Society, 142(5), 1238-1259. https://doi.org/10.1080/00028487.2013.799518

Roslin, T., \& Majaneva, S. (2016). The use of DNA barcodes in food web constructionTerrestrial and aquatic ecologists unite! Genome, 59(9), 603-628. https://doi.org/10.1139/gen-2015-0229

Sampey, A., McKinnon, A., Meekan, M., \& McCormick, M. (2007). Glimpse into guts: Overview of the feeding of larvae of tropical shorefishes. Marine Ecology Progress Series, 339, 243-257. https://doi.org/10.3354/meps339243

Schoener, T. W. (1970). Nonsynchronous Spatial Overlap of Lizards in Patchy Habitats. Ecology, 51(3), 408-418. https://doi.org/10.2307/1935376

Schooley, J. D., Karam, A. P., Kesner, B. R., Marsh, P. C., Pacey, C. A., \& Thornbrugh, D. J. (2008). Detection of larval remains after consumption by fishes. Transactions of the American Fisheries Society, 137, 1044-1049.

Sirois, P., \& Dodson, J. (2000). Influence of turbidity, food density and parasites on the ingestion and growth of larval rainbow smelt Osmerus mordax in an estuarine turbidity maximum. Marine Ecology Progress Series, 193, 167-179. https://doi.org/10.3354/meps 193167

Slater, S. B. (2015). Feeding Habits of Longfin Smelt in the Upper San Francisco Estuary [Poster]. Interagency Ecological Program Workshop, Folsom, CA. https://www.researchgate.net/publication/278728659_Feeding_Habits_of_Longfin_Smelt in_the_Upper_San_Francisco_Estuary

Slater, S., \& Baxter, R. (2014). Diet, Prey Selection, and Body Condition of Age-0 Delta Smelt, Hypomesus transpacificus, in the Upper San Francisco Estuary. San Francisco Estuary and Watershed Science, 12(3). https://doi.org/10.15447/sfews.2014v12iss3art1

Sommer, T., Armor, C., Baxter, R., Breuer, R., Brown, L., Chotkowski, M., Culberson, S., Feyrer, F., Gingras, M., Herbold, B., Kimmerer, W., Mueller Solger, A., Nobriga, M., \& 
Souza, K. (2007). The collapse of pelagic fishes in the upper San Francisco Estuary. Fisheries, 32, 270-277.

Sousa, L. L. de, Silva, S. M., \& Xavier, R. (2019). DNA metabarcoding in diet studies: Unveiling ecological aspects in aquatic and terrestrial ecosystems. Environmental DNA, 1(3), 199-214. https://doi.org/10.1002/edn3.27

Stoecker, D. K., \& Capuzzo, J. M. (1990). Predation on Protozoa: Its importance to zooplankton. Journal of Plankton Research, 12(5), 891-908. https://doi.org/10.1093/plankt/12.5.891

Sullivan, L. J., Ignoffo, T. R., Baskerville-Bridges, B., Ostrach, D. J., \& Kimmerer, W. J. (2016). Prey selection of larval and juvenile planktivorous fish: Impacts of introduced prey. Environmental Biology of Fishes, 99(8-9), 633-646. https://doi.org/10.1007/s10641-0160505-x

Thomson, J. R., Kimmerer, W. J., Brown, L. R., Newman, K. B., Nally, R. M., Bennett, W. A., Feyrer, F., \& Fleishman, E. (2010). Bayesian change point analysis of abundance trends for pelagic fishes in the upper San Francisco Estuary. Ecological Applications, 20(5), 1431-1448. https://doi.org/10.1890/09-0998

Torniainen, J., \& Lehtiniemi, M. (2008). Potential predation pressure of littoral mysids on herring (Clupea harengus membras L.) eggs and yolk-sac larvae. Journal of Experimental Marine Biology and Ecology, 367(2), 247-252. https://doi.org/10.1016/j.jembe.2008.10.007

Vestheim, H., \& Jarman, S. N. (2008). Blocking primers to enhance PCR amplification of rare sequences in mixed samples - a case study on prey DNA in Antarctic krill stomachs. Frontiers in Zoology, 5(1), 12. https://doi.org/10.1186/1742-9994-5-12

Wailes, G. H. (1936). Food of Clupea pallasii in Southern British Columbia Waters. Journal of the Biological Board of Canada, 1(6), 477-486. https://doi.org/10.1139/f35-014

Wallace, R. K. (1981). An Assessment of Diet-Overlap Indexes. Transactions of the American Fisheries Society, 110, 72-76.

Walters, C. J., \& Juanes, F. (1993). Recruitment Limitation as a Consequence of Natural Selection for Use of Restricted Feeding Habitats and Predation Risk Taking by Juvenile Fishes. Canadian Journal of Fisheries and Aquatic Sciences, 50(10), 2058-2070. https://doi.org/10.1139/f93-229

Walters, C., \& Korman, J. (1999). Linking recruitment to trophic factors: Revisiting the Beverton-Holt recruitment model from a life history and multispecies perspective. Reviews in Fish Biology and Fisheries, 9(2), 187-202. https://doi.org/10.1023/a:1008991021305 
Wang, Q., Garrity, G. M., Tiedje, J. M., \& Cole, J. R. (2007). Naive Bayesian Classifier for Rapid Assignment of rRNA Sequences into the New Bacterial Taxonomy. Applied and Environmental Microbiology, 73(16), 5261-5267. https://doi.org/10.1128/AEM.00062$\underline{07}$

1304

1305

1306

1307

1308

1309

1310

1311

1312

1313

1314

1315

1316

1317

1318

1319

1320
Waraniak, J. M., Marsh, T. L., \& Scribner, K. T. (2019). 18S rRNA metabarcoding diet analysis of a predatory fish community across seasonal changes in prey availability. Ecology and Evolution, 9(3), 1410-1430. https://doi.org/10.1002/ece3.4857

Watters, D. L., Brown, H. M., Griffin, F. J., Larson, E. J., \& Cherr, G. N. (2004). Pacific Herring Spawning Grounds in San Francisco Bay: 1973-2000. In F. Feyrer, L. R. Brown, R. L. Brown, \& J. J. Orsi (Eds.), Early Life History of Fishes in the San Francisco Estuary and Watershed (pp. 14-Mar). American Fisheries Society.

Wyatt, T. (1972). Some effects of food density on the growth and behaviour of plaice larvae. Marine Biology, 14(3), 210-216.

Zhang, G. K., Chain, F. J. J., Abbott, C. L., \& Cristescu, M. E. (2018). Metabarcoding using multiplexed markers increases species detection in complex zooplankton communities. Evolutionary Applications, 11(10), 1901-1914. https://doi.org/10.1111/eva.12694

Zhang, J., Kobert, K., Flouri, T., \& Stamatakis, A. (2014). PEAR: A fast and accurate Illumina Paired-End reAd mergeR. Bioinformatics, 30(5), 614-620. https://doi.org/10.1093/bioinformatics/btt593 


\section{$1321 \quad \underline{\text { Figures }}$}

1322
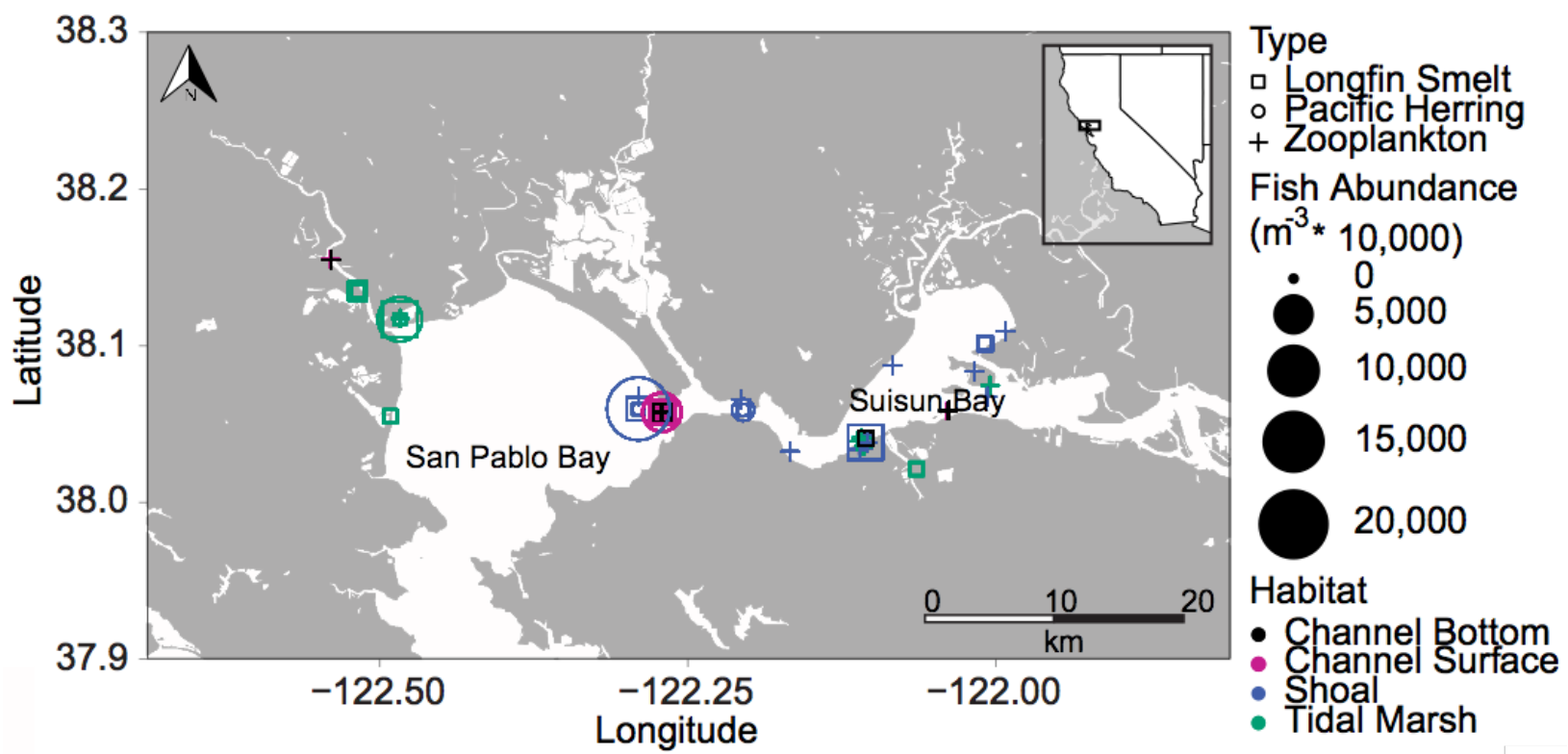

1324 Figure 1: Map of sample sites in the northern San Francisco Estuary; inset shows location in

1325 California, western United States. Sites were surveyed for longfin smelt and Pacific herring.

1326 Shapes indicate where longfin smelt (squares), Pacific herring (circles), or zooplankton without

1327 fish (cross) were sampled. Zooplankton were also sampled where fish were collected. For

1328 squares and circles, the size of the point indicates the fish abundance $\left(m^{-3} \times 10,000\right)$. Habitats

1329 are indicated with color: channel bottom (black), channel surface (pink), shoal (blue), or tidal

1330 marsh (green). 


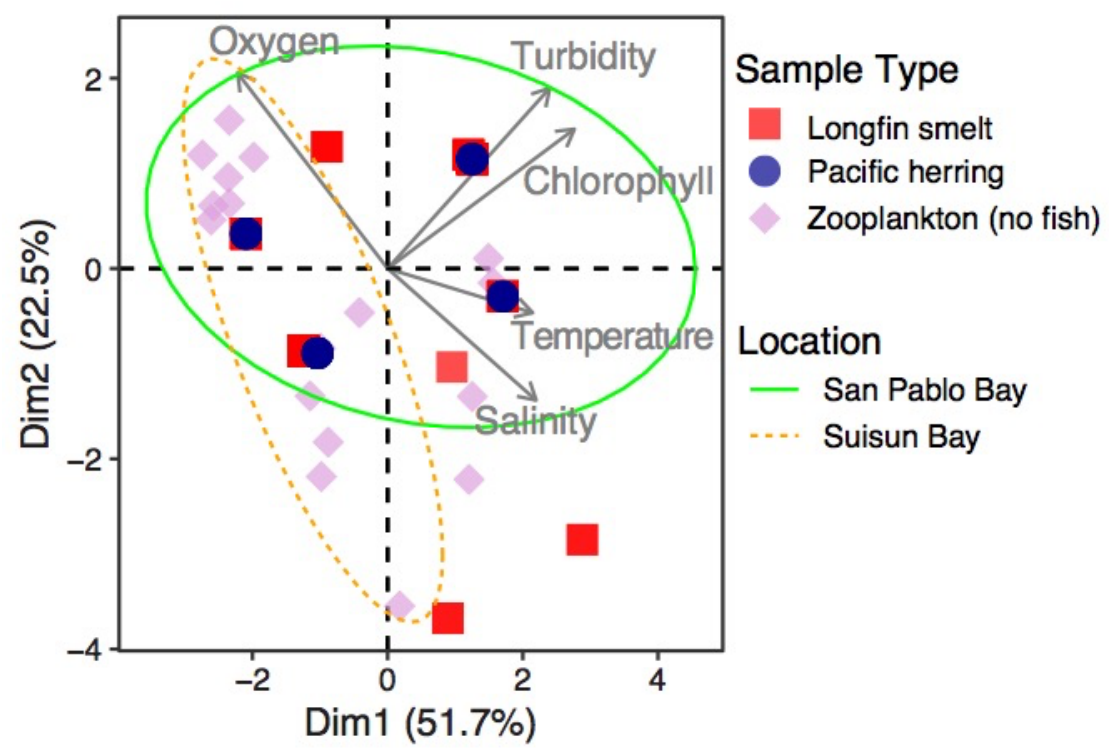

1336

1337

1338

1339

1340

1341

1342

1343

1344 


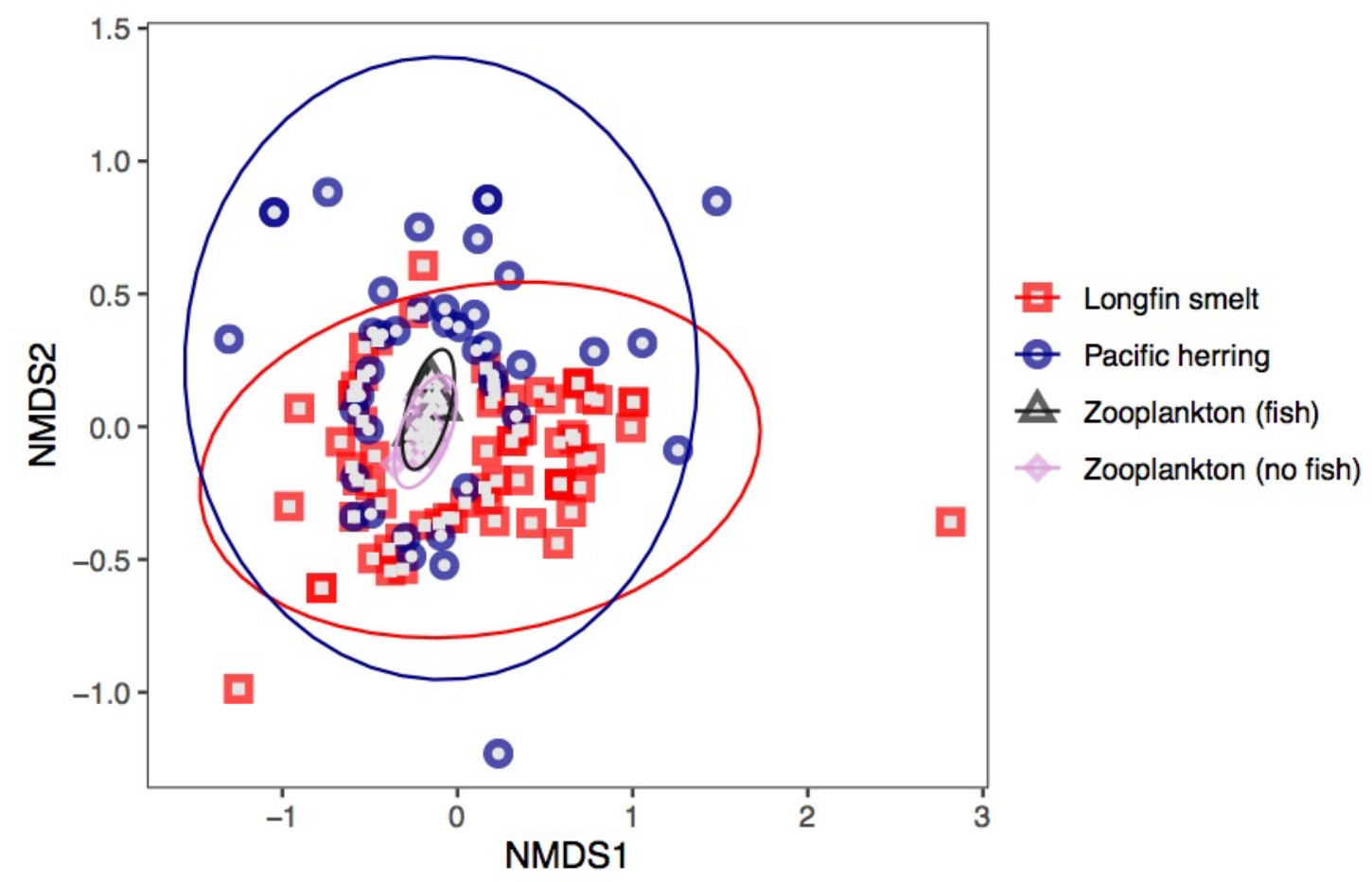

1346

1347

1348

1349

1350

1351

1352

1353

Figure 3. NMDS plot of normalized sequence diversity in each sample, with colors representing different types of samples: longfin smelt (individual or paired guts; red square), Pacific herring (individual guts; blue circle), zooplankton samples associated with fish (grey triangle), and zooplankton samples without fish (pink diamond). Ellipses represent 95\% confidence groupings of each sample type. 
B

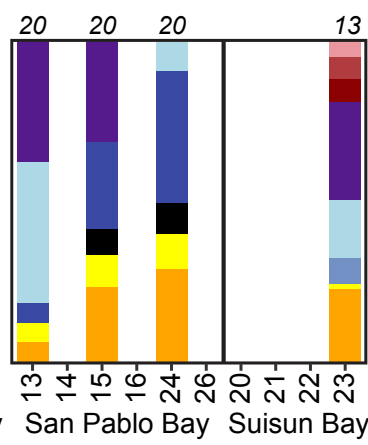
13

C

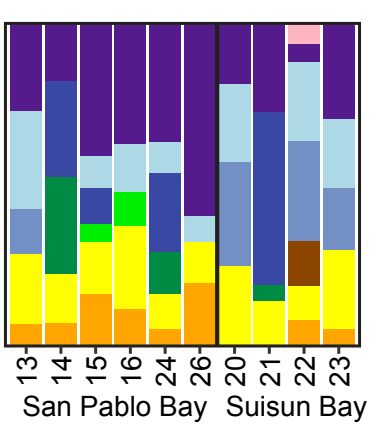

Bosmina longirostris Ceriodaphnia laticaudata Ceriodaphnia sp. Daphnia sp. Daphnia sp. Acanthocyclops americanus Acanthocyops robustus Limnoithona tetraspina Cyclopoida $C$ Harpacticoida A Liposcelis rufa Clupea pallasii Spirinchus thaleichthys Cottus asper Hydra oligactis Non-metazoans Other $(<5 \%$

Unknown

1366 Figure 4: Relative read abundance (RRA\%) in (A) longfin smelt (means for each tow), (B)

1367 Pacific herring (means for each tow), and (C) zooplankton samples associated with fish.

1368 Numbers above bars indicate the number of fish gut samples sequenced. "Other" includes prey

1369 IDs that contributed $<5 \%$ to the sample. "Unknowns" are those with $<80 \%$ RDP bootstrap

1370 confidence for ID. *empty gut. 
A

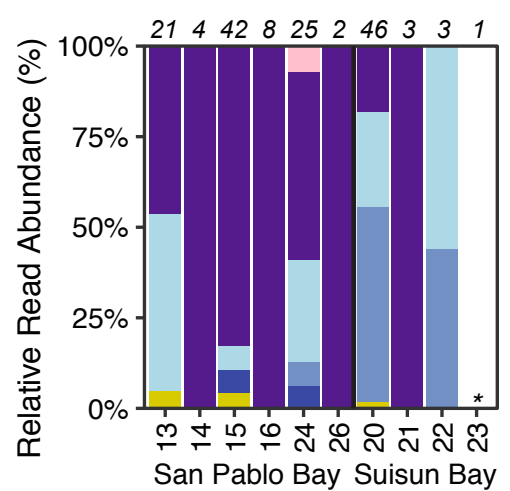

B

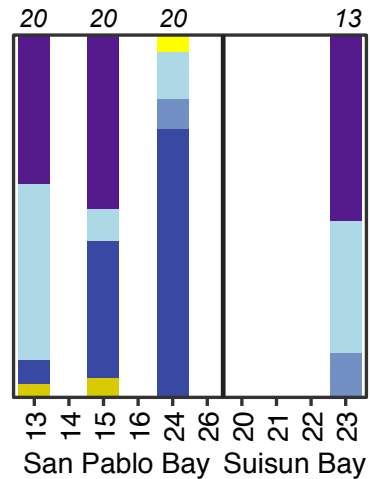

Tow \#, Location
C

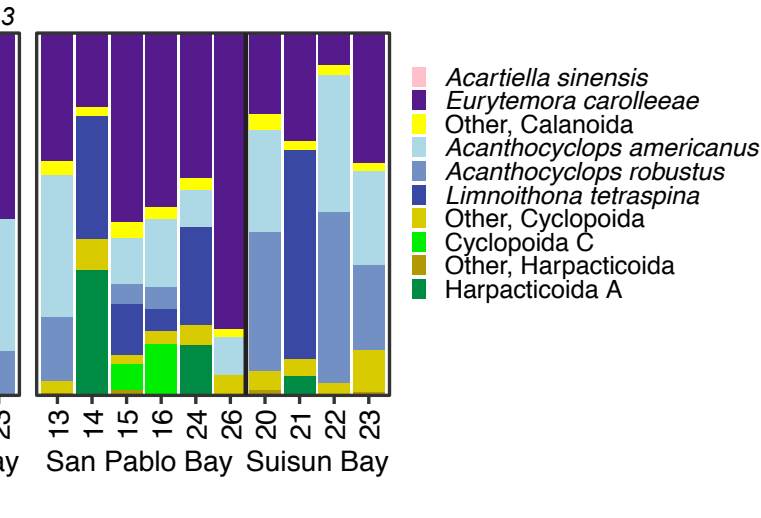

Figure 5: Relative read abundance (RRA \%) of copepoda only, in (A) longfin smelt (means for with fish. Numbers above bars indicate the number of fish gut samples sequenced. "Others" include prey IDs in each Order with $<5 \%$ contribution to the sample. *empty gut. 


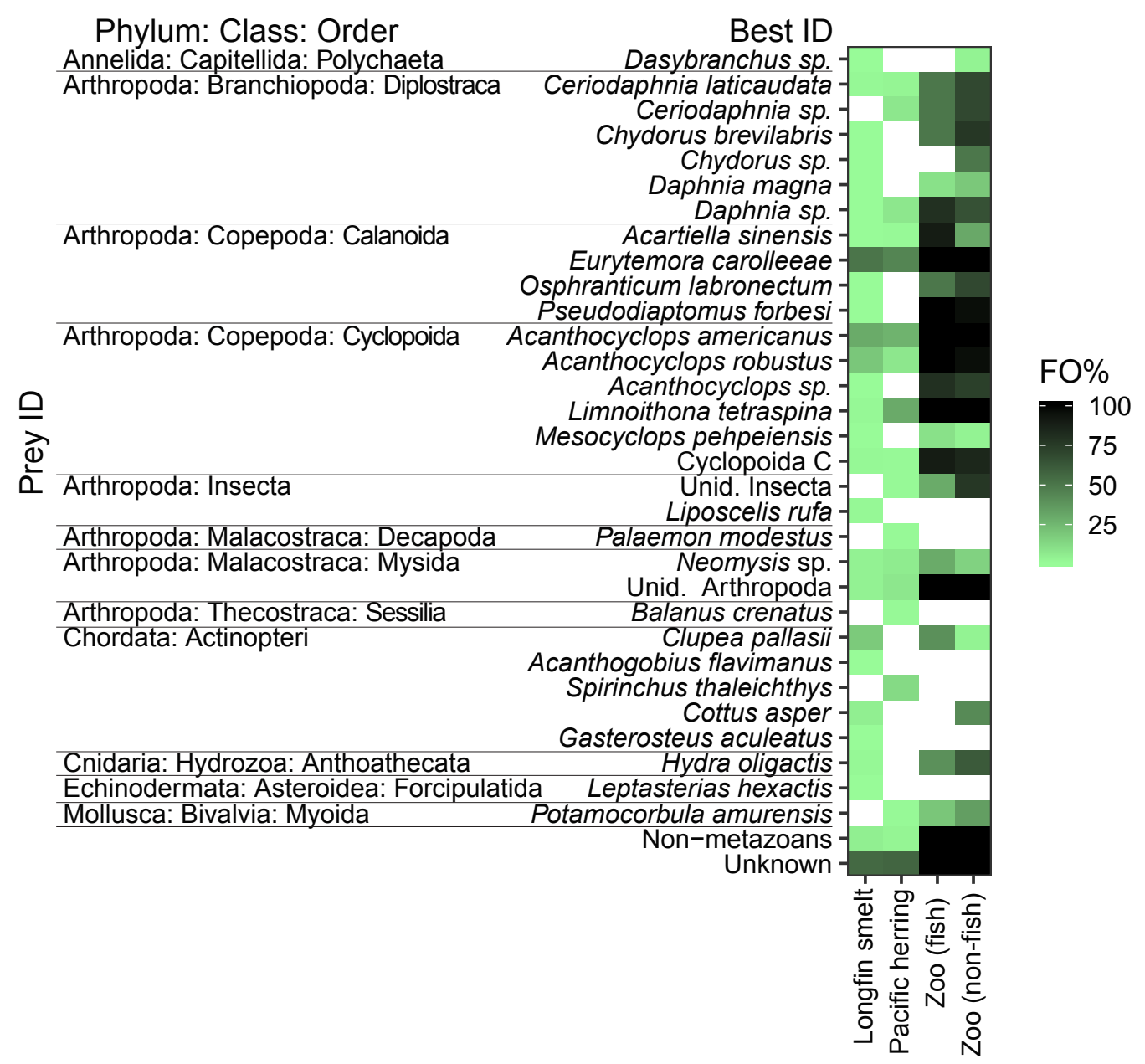
types: longfin smelt, Pacific herring, zooplankton with fish (Zoo (fish)), and zooplankton without

1383 fish (Zoo (no fish)). Only prey taxa found in either longfin smelt or herring are shown here.

1384 White boxes indicate $F O=0 \%$. 


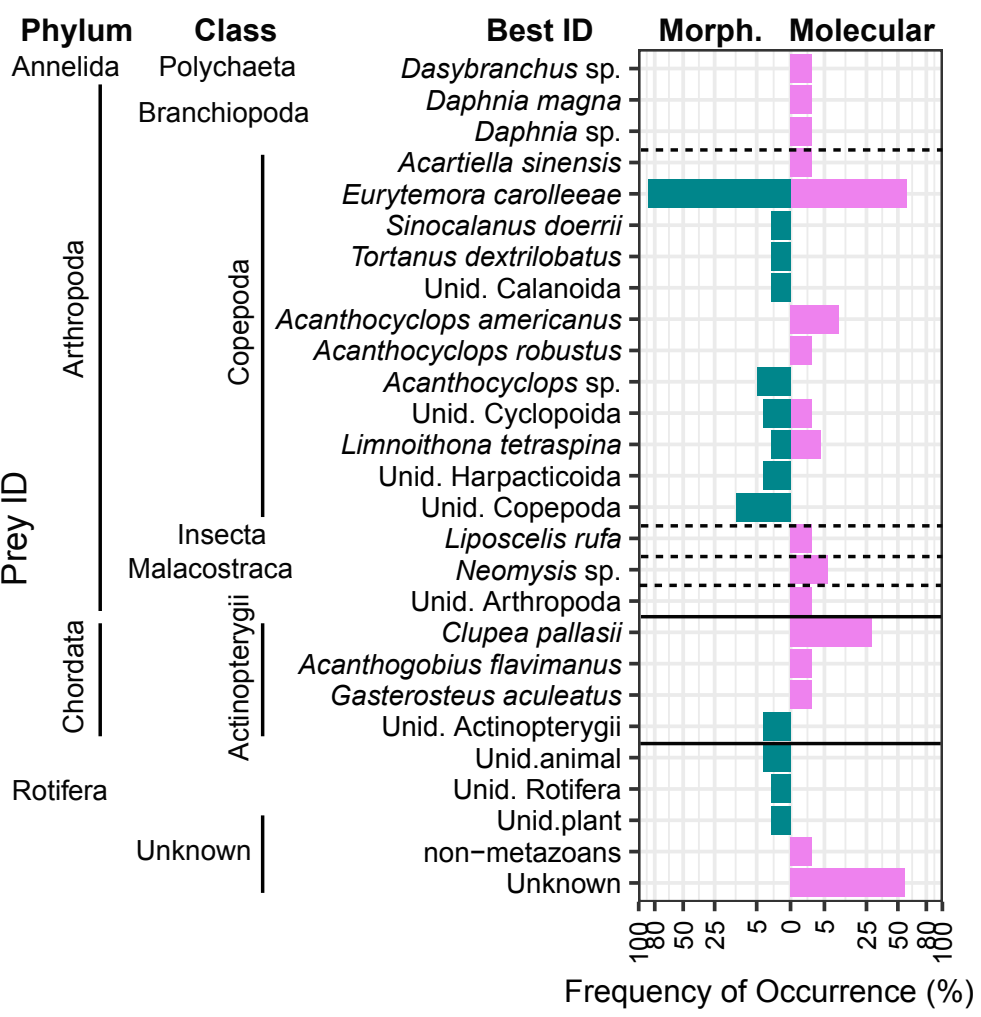

1397 Figure 7: Comparison of the frequency of occurrence (FO \%) of prey in longfin smelt diets 1398 obtained through morphological (morph.: turquoise bars) and molecular analysis (pink bars). 1399 Unid. indicates an unidentified organism of that general type. Note the $x$-axis is square-root 1400 transformed to expand the small values. 


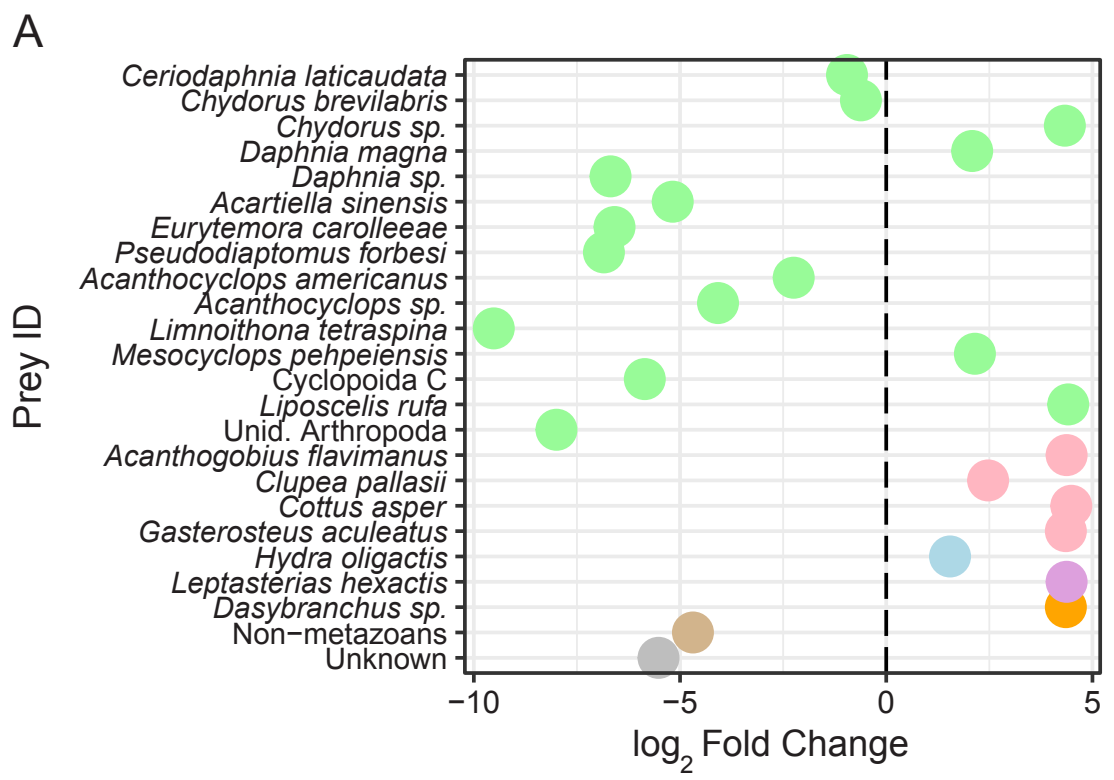

Phylum
Annelida
Chordata
Echinodermata
Unknown
Arthropoda
Cnidaria
non-metazoans

B

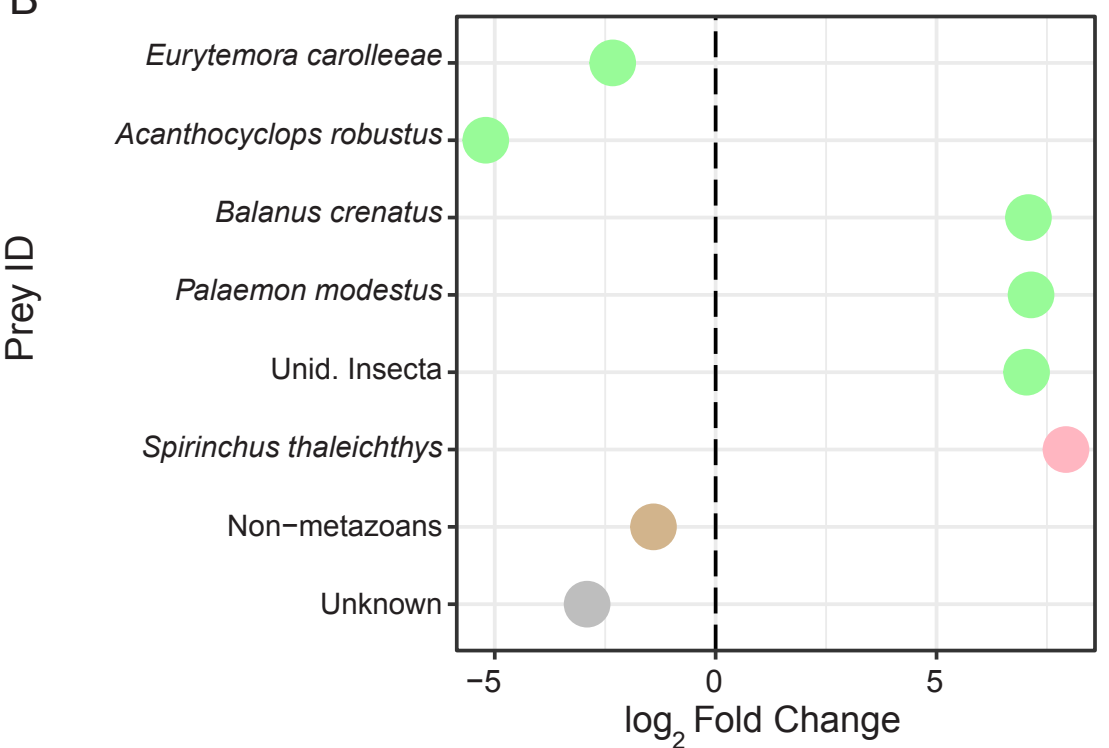

1405 Figure 8: Differential abundance ( $\log _{2}$ fold change) comparing the abundance of prey taxa from

1406 (A) longfin smelt guts and (B) Pacific herring guts with those from zooplankton samples. Prey

1407 types include only those present both in the guts and in the zooplankton. Positive fold change

1408 indicates prey relative abundance was higher in gut than in the zooplankton, negative fold

1409 change indicates prey relative abundance was lower in the gut than in the zooplankton. 


\section{Supplementarv Tables}

1411

1412 Supplementary Table 1. Non-actinopterygian chordates identified with BLASTn, with >=97\% identity to Phylum Chordata .

1413

\begin{tabular}{|c|c|c|c|c|c|c|c|c|c|c|c|c|}
\hline Sample Type & SampleID & ASV & $\%$ ID & E-value & Phylum & Class & Order & Family & Genus & Species & Accession & Reads \\
\hline $\begin{array}{l}\text { longfin smelt } \\
\text { mixed }\end{array}$ & LLF58 & ASV_8302 & 99.7 & $1.18 \mathrm{E}-155$ & Chordata & Mammalia & Carnivora & Felidae & Felis & Felis silvestris lybica & KP202275.1 & 24 \\
\hline zooplankton & $\mathrm{Z} 27$ & ASV_3600 & 100 & $2.77 \mathrm{E}-157$ & Chordata & Mammalia & Primates & Hominidae & Homo & Homo sapiens & MK618711.1 & 8 \\
\hline longfin smelt & LLF35 & ASV 22093 & 100 & $2.77 \mathrm{E}-157$ & Chordata & Mammalia & - & Suidae & Sus & Sus scrofa & MF398983.1 & 5 \\
\hline
\end{tabular}

1414

1415

1416

1417 
1418 Supplementary Table 2. Summary of Reads and ASVs in different sample types (longfin smelt 1419 guts, Pacific herring guts, zooplankton and controls), at each step of quality checking and data

1420 filtration (DADA2, size-based filtration, and taxonomy-based filtration, performed sequentially),

1421 and in different levels (metazoans, non-metazoans, unknowns) after taxonomy-based filtration.

\begin{tabular}{|c|c|c|c|c|c|}
\hline & $\begin{array}{l}\text { Longfin } \\
\text { Smelt Guts }\end{array}$ & $\begin{array}{c}\text { Pacific } \\
\text { Herring } \\
\text { Guts }\end{array}$ & Zooplankton & Controls & Total \\
\hline \# Samples Sequenced & 111 & 73 & 36 & 10 & \\
\hline Raw Reads & $1,284,353$ & $1,251,539$ & $7,972,137$ & 97,620 & $10,576,006$ \\
\hline DADA-filtered Reads & 222,970 & 191,049 & $4,559,113$ & 3,835 & $4,976,967$ \\
\hline$D A D A-A S V S$ & 1,716 & 2,945 & 28,457 & 65 & 32,736 \\
\hline Size-filtered Reads & 130,235 & 109,797 & $4,048,937$ & 1,522 & $4,290,491$ \\
\hline Size-filtered $A S V$ & 157 & 124 & 9,636 & 26 & 9,779 \\
\hline $\begin{array}{l}\text { Taxonomy-filtered Reads } \\
\text { (Final) }\end{array}$ & 78,910 & 59,696 & $4,032,426$ & 1,166 & $4,172,198$ \\
\hline Taxonomy-filtered ASVs & 116 & 99 & 9,474 & 22 & 9,557 \\
\hline $\begin{array}{l}\text { Percent of Raw Reads in Final } \\
\text { Data }\end{array}$ & $6 \%$ & $5 \%$ & $51 \%$ & $1 \%$ & $39 \%$ \\
\hline \multicolumn{6}{|l|}{ Reads/Sample } \\
\hline Median & 198 & 176 & 113,669 & 38.5 & \\
\hline SD & 1,183 & 1,332 & 53,333 & 153 & \\
\hline Min & 3 & 2 & 22,129 & 6 & \\
\hline $\operatorname{Max}$ & 4,206 & 5,564 & 199,759 & 442 & \\
\hline \multicolumn{6}{|l|}{ Taxonomic Groups } \\
\hline \multicolumn{6}{|l|}{$\underline{\text { Metazoans }}$} \\
\hline \# Metazoan Reads & 74,952 & 53,016 & $3,321,383$ & 1016 & $3,450,367$ \\
\hline$\%$ of Total Reads & $1.8 \%$ & $1.3 \%$ & $79.6 \%$ & $0.0 \%$ & $82.7 \%$ \\
\hline \# ASVs & 76 & 56 & 3,906 & 13 & 3944 \\
\hline \multicolumn{6}{|l|}{$\underline{\text { Non-metazoans }}$} \\
\hline \# Non-metazoan Reads & 41 & 4 & 203,015 & 64 & 203,124 \\
\hline$\%$ of Total Reads & $0.0 \%$ & $0.0 \%$ & $4.9 \%$ & $0.0 \%$ & $4.9 \%$ \\
\hline \# ASVs & 5 & 2 & 280 & 5 & 286 \\
\hline \multicolumn{6}{|l|}{$\underline{\text { Unknowns }}$} \\
\hline \# Unknown reads & 3,917 & 6,676 & 508,028 & 86 & 518,707 \\
\hline$\%$ of Total Reads & $0.1 \%$ & $0.2 \%$ & $12.2 \%$ & $0.0 \%$ & $12.4 \%$ \\
\hline \# ASVs & 35 & 41 & 5,288 & 4 & 5327 \\
\hline
\end{tabular}


1422 Supplementary Table 3. Individually identified and DNA barcoded cyclopoid and harpacticoid 1423 copepods, primer sets tested, sequencing result, and NCBI Accession Number if sequence was 1424 submitted to the database.

\begin{tabular}{|c|c|c|c|c|c|}
\hline Order & Putative Morphological ID & $\begin{array}{c}\text { ID } \\
\text { Code }\end{array}$ & Primer set & Result & $\begin{array}{c}\text { NCBI Accession } \\
\text { Number }\end{array}$ \\
\hline \multirow[t]{24}{*}{ Cyclopoida } & Acanthocyclops americanus & CCA & $\begin{array}{l}\mathrm{mlCOIintF} / \\
\mathrm{jgHCO} 2198\end{array}$ & good & (for our sequence) \\
\hline & Acanthocyclops robustus & CCB1 & $\begin{array}{l}\text { LCO1490/ } \\
\text { jgHCO2198 }\end{array}$ & good & N/A \\
\hline & Acanthocyclops robustus & CCB2 & both & no amp & N/A \\
\hline & Acanthocyclops robustus & CCB3 & both & no amp & N/A \\
\hline & Acanthocyclops robustus & CCB4 & $\begin{array}{l}\text { mlCOIintF/ } \\
\text { jgHCO2198 }\end{array}$ & $\begin{array}{l}\text { non- } \\
\text { target }\end{array}$ & N/A \\
\hline & Acanthocyclops robustus & CCB5 & both & no amp & N/A \\
\hline & Homocyclops spp. & $\mathrm{CCC} 1$ & $\begin{array}{c}\text { LCO1490/ } \\
\text { jgHCO2198 }\end{array}$ & good & N/A \\
\hline & Homocyclops spp. & $\mathrm{CCC} 2$ & $\begin{array}{l}\mathrm{mlCOIintF} / \\
\mathrm{jgHCO} 2198\end{array}$ & $\begin{array}{l}\text { non- } \\
\text { target }\end{array}$ & N/A \\
\hline & Acanthocyclops capillatus & CCD1 & $\begin{array}{l}\mathrm{mlCOIintF} / \\
\mathrm{jgHCO} 2198\end{array}$ & no amp & N/A \\
\hline & Acanthocyclops capillatus & $\mathrm{CCD} 2$ & $\begin{array}{l}\text { mlCOIintF/ } \\
\text { jgHCO2198 }\end{array}$ & no amp & N/A \\
\hline & Acanthocyclops capillatus & CCD3 & both & no amp & N/A \\
\hline & Acanthocyclops robustus & CCE1 & $\begin{array}{l}\text { mlCOIintF/ } \\
\text { jgHCO2198 }\end{array}$ & $\begin{array}{c}\text { non- } \\
\text { target }\end{array}$ & N/A \\
\hline & Acanthocyclops robustus & CCE2 & both & no amp & N/A \\
\hline & Acanthocyclops robustus & CCE3 & $\begin{array}{l}\mathrm{mlCOIintF} / \\
\text { jgHCO2198 }\end{array}$ & $\begin{array}{l}\text { non- } \\
\text { target }\end{array}$ & N/A \\
\hline & Acanthocyclops robustus & CCE4 & $\begin{array}{l}\mathrm{LCO} 1490 / \\
\mathrm{jgHCO} 2198\end{array}$ & good & N/A \\
\hline & Acanthocyclops robustus & CCE5 & both & no amp & N/A \\
\hline & Mesocyclops pehpeiensis & $\mathrm{CCF}$ & $\begin{array}{l}\mathrm{mlCOIintF} / \\
\mathrm{jgHCO} 2198\end{array}$ & good & (for our sequence) \\
\hline & $\begin{array}{c}\text { Diacyclops thomasi or } \\
\text { Acanthocyclops capillatus }\end{array}$ & CCG1 & $\begin{array}{l}\mathrm{mlCOIintF} / \\
\mathrm{jgHCO} 2198\end{array}$ & good & N/A \\
\hline & $\begin{array}{c}\text { Diacyclops thomasi or } \\
\text { Acanthocyclops capillatus }\end{array}$ & $\mathrm{CCG} 2$ & $\begin{array}{l}\mathrm{mlCOIintF} / \\
\mathrm{jgHCO} 2198\end{array}$ & $\begin{array}{l}\text { non- } \\
\text { target }\end{array}$ & N/A \\
\hline & $\begin{array}{l}\text { Diacyclops thomasi or } \\
\text { Acanthocyclops capillatus }\end{array}$ & CCG3 & both & no amp & N/A \\
\hline & $\begin{array}{l}\text { Diacyclops thomasi or } \\
\text { Acanthocyclops capillatus }\end{array}$ & CCG4 & $\begin{array}{l}\mathrm{mlCOIintF} / \\
\mathrm{jgHCO} 2198\end{array}$ & $\begin{array}{l}\text { non- } \\
\text { target }\end{array}$ & N/A \\
\hline & Cyclops scutifer & $\mathrm{CCH} 1$ & $\begin{array}{l}\mathrm{mlCOIintF} / \\
\mathrm{jgHCO} 2198\end{array}$ & $\begin{array}{l}\text { non- } \\
\text { target }\end{array}$ & N/A \\
\hline & Cyclops scutifer & $\mathrm{CCH} 2$ & both & no amp & N/A \\
\hline & Eucyclops elegans or agilis & $\mathrm{CCI}$ & $\begin{array}{l}\text { mlCOIintF/ } \\
\text { jgHCO2198 }\end{array}$ & $\begin{array}{l}\text { non- } \\
\text { target }\end{array}$ & N/A \\
\hline
\end{tabular}




\begin{tabular}{|c|c|c|c|c|c|}
\hline & Unknown cyclopoida & $\mathrm{CCJ}$ & both & no amp & N/A \\
\hline & Macrocyclops distinctus & CCK & $\begin{array}{c}\text { LCO1490/ } \\
\text { jgHCO2198 }\end{array}$ & good & N/A \\
\hline & Limnoithona tetraspina & CL1 & $\begin{array}{l}\text { mlCOIintF/ } \\
\text { jgHCO2198 }\end{array}$ & good & (for our sequence) \\
\hline & Limnoithona tetraspina & CL2 & $\begin{array}{l}\text { mlCOIintF/ } \\
\text { jgHCO2198 }\end{array}$ & good & (for our sequence) \\
\hline & Limnoithona tetraspina & CL3 & $\begin{array}{l}\text { mlCOIintF/ } \\
\text { jgHCO2198 }\end{array}$ & good & (for our sequence) \\
\hline & Limnoithona tetraspina & CL4 & $\begin{array}{l}\text { mlCOIintF/ } \\
\text { jgHCO2198 }\end{array}$ & good & (for our sequence) \\
\hline & Limnoithona tetraspina & CL5 & $\begin{array}{l}\text { mlCOIintF/ } \\
\text { jgHCO2198 }\end{array}$ & good & (for our sequence) \\
\hline \multirow[t]{11}{*}{ Harpacticoida } & Euterpina acutifrons & H1 & $\begin{array}{c}\text { LCO1490/ } \\
\text { jgHCO2198 }\end{array}$ & good & N/A \\
\hline & Euterpina acutifrons & $\mathrm{H} 2$ & $\begin{array}{c}\text { LCO1490/ } \\
\text { jgHCO2198 }\end{array}$ & good & N/A \\
\hline & Euterpina acutifrons & $\mathrm{H} 3$ & $\begin{array}{c}\text { LCO1490/ } \\
\text { jgHCO2198 }\end{array}$ & good & N/A \\
\hline & Euterpina acutifrons & H4 & $\begin{array}{l}\text { mlCOIintF/ } \\
\text { jgHCO2198 }\end{array}$ & good & N/A \\
\hline & Euterpina acutifrons & H5 & $\begin{array}{c}\text { LCO1490/ } \\
\text { jgHCO2198 }\end{array}$ & good & $\mathrm{N} / \mathrm{A}$ \\
\hline & Euterpina acutifrons & H6 & $\begin{array}{c}\text { LCO1490/ } \\
\text { jgHCO2198 }\end{array}$ & good & N/A \\
\hline & Euterpina acutifrons & $\mathrm{H} 7$ & $\begin{array}{c}\text { LCO1490/ } \\
\text { jgHCO2198 }\end{array}$ & good & $\mathrm{N} / \mathrm{A}$ \\
\hline & Euterpina acutifrons & $\mathrm{H} 8$ & both & $\operatorname{good}^{*}$ & N/A \\
\hline & Euterpina acutifrons & H9 & $\begin{array}{c}\text { LCO1490/ } \\
\text { jgHCO2198 }\end{array}$ & good & N/A \\
\hline & Euterpina acutifrons & H10 & $\begin{array}{c}\text { mlCOIintF/ } \\
\text { jgHCO2198 }\end{array}$ & good & N/A \\
\hline & Pseudobradya sp. & HG & $\begin{array}{l}\text { mlCOIintF/ } \\
\text { jgHCO2198 }\end{array}$ & good & N/A \\
\hline
\end{tabular}


1427 Supplementary Table 4. Frequency of occurrence (FO\%) and Relative Read Abundance (RRA\%)

1428 of high-level confidence ID's in fish guts and zooplankton.

\begin{tabular}{|c|c|c|c|c|c|c|c|c|c|c|c|}
\hline \multirow[b]{2}{*}{ Phylum } & \multirow[b]{2}{*}{ Class } & \multirow[b]{2}{*}{ Order } & \multirow[b]{2}{*}{ Best ID } & \multicolumn{4}{|c|}{ FO (\%) } & \multicolumn{4}{|c|}{ RRA (\%) } \\
\hline & & & & LF & PH & $\begin{array}{l}\text { ZOO } \\
\text {.fish } \\
\end{array}$ & $\begin{array}{l}\text { ZOO. } \\
\text { nofish }\end{array}$ & $\mathbf{L F}$ & PH & $\begin{array}{c}\text { ZOO. } \\
\text { fish }\end{array}$ & $\begin{array}{l}\text { ZOO. } \\
\text { nofish }\end{array}$ \\
\hline Annelida & Clitellata & Enchytraeida & $\begin{array}{l}\text { Lumbricillu } \\
\text { s rubidus }\end{array}$ & NA & NA & NA & 3.9 & NA & NA & NA & 0.001 \\
\hline Annelida & Clitellata & Haplotaxida & $\begin{array}{l}\text { Amphichaet } \\
\text { a sannio } \\
\text { Chaetogaste }\end{array}$ & NA & NA & 30.0 & 23.1 & NA & NA & 0.016 & 0.008 \\
\hline Annelida & Clitellata & Haplotaxida & $\begin{array}{l}\mathrm{r} \\
\text { diastrophus }\end{array}$ & NA & NA & 10.0 & 23.1 & NA & NA & 0.024 & 0.054 \\
\hline Annelida & Clitellata & Haplotaxida & $\begin{array}{l}\text { Chaetogaste } \\
\text { r limnaei }\end{array}$ & NA & NA & NA & 7.7 & NA & NA & NA & 0.000 \\
\hline Annelida & Clitellata & Haplotaxida & Naididae & NA & NA & NA & 15.4 & NA & NA & NA & 0.012 \\
\hline Annelida & Clitellata & Haplotaxida & Dero sp. & NA & NA & NA & 3.9 & NA & NA & NA & 0.000 \\
\hline Annelida & Clitellata & Haplotaxida & Nais sp. & NA & NA & NA & 11.5 & NA & NA & NA & 0.040 \\
\hline Annelida & Clitellata & Haplotaxida & $\begin{array}{l}\text { Nais } \\
\text { elinguis }\end{array}$ & NA & NA & NA & 11.5 & NA & NA & NA & 0.028 \\
\hline Annelida & Clitellata & Haplotaxida & $\begin{array}{l}\text { Nais } \\
\text { variabilis }\end{array}$ & NA & NA & NA & 3.9 & NA & NA & NA & 0.014 \\
\hline Annelida & Clitellata & Haplotaxida & $\begin{array}{l}\text { Paranais } \\
\text { botniensis }\end{array}$ & NA & NA & 10.0 & 3.9 & NA & NA & 0.029 & 0.012 \\
\hline Annelida & Clitellata & Haplotaxida & $\begin{array}{l}\text { Paranais } \\
\text { frici }\end{array}$ & NA & NA & 10.0 & 15.4 & NA & NA & 0.001 & 0.236 \\
\hline Annelida & Clitellata & Haplotaxida & $\begin{array}{l}\text { Paranais } \\
\text { litoralis }\end{array}$ & NA & NA & 20.0 & 7.7 & NA & NA & 0.009 & 0.011 \\
\hline Annelida & Clitellata & Haplotaxida & $\begin{array}{l}\text { Specaria } \\
\text { josinae }\end{array}$ & NA & NA & NA & 3.9 & NA & NA & NA & 0.021 \\
\hline \multirow[t]{2}{*}{ Annelida } & Clitellata & Haplotaxida & $\begin{array}{l}\text { Tubificoide } \\
\text { s fraseri } \\
\text { Tubificoide }\end{array}$ & NA & NA & 10.0 & 7.7 & NA & NA & 0.014 & 0.001 \\
\hline & & & $\begin{array}{l}\text { s } \\
\text { heterochaet }\end{array}$ & NA & NA & NA & 7.7 & & & & \\
\hline Annelida & Clitellata & Haplotaxida & us & & & & & NA & NA & NA & 0.004 \\
\hline Annelida & Clitellata & Haplotaxida & $\begin{array}{l}\text { Vejdovskye } \\
\text { lla sp. }\end{array}$ & NA & NA & NA & 11.5 & NA & NA & NA & 0.015 \\
\hline Annelida & Polychaeta & Capitellida & $\begin{array}{l}\text { Capitellidae } \\
\text { sp. }\end{array}$ & NA & NA & 10.0 & 15.4 & NA & NA & 0.021 & 0.012 \\
\hline Annelida & Polychaeta & Capitellida & $\begin{array}{l}\text { Dasybranch } \\
\text { us sp. }\end{array}$ & 1.0 & NA & NA & 3.9 & 0.002 & NA & NA & 0.000 \\
\hline Annelida & Polychaeta & Capitellida & $\begin{array}{l}\text { Mediomastu } \\
\text { s sp. }\end{array}$ & NA & NA & 10.0 & 7.7 & NA & NA & 0.008 & 0.002 \\
\hline Annelida & Polychaeta & Phyllodocida & $\begin{array}{l}\text { Alitta } \\
\text { succinea }\end{array}$ & NA & NA & 20.0 & 38.5 & NA & NA & 0.059 & 0.536 \\
\hline Annelida & Polychaeta & Phyllodocida & $\begin{array}{l}\text { Glycinde } \\
\text { picta }\end{array}$ & NA & NA & 10.0 & 11.5 & NA & NA & 0.002 & 0.004 \\
\hline Annelida & Polychaeta & Phyllodocida & $\begin{array}{l}\text { Glycinde } \\
\text { sp. }\end{array}$ & NA & NA & NA & 7.7 & NA & NA & NA & 0.001 \\
\hline Annelida & Polychaeta & Phyllodocida & $\begin{array}{l}\text { Hediste } \\
\text { diversicolor }\end{array}$ & NA & NA & 20.0 & 26.9 & NA & NA & 0.025 & 0.741 \\
\hline
\end{tabular}




\begin{tabular}{|c|c|c|c|c|c|c|c|c|c|c|c|}
\hline \multirow[b]{2}{*}{ Phylum } & \multirow[b]{2}{*}{ Class } & \multirow[b]{2}{*}{ Order } & \multirow[b]{2}{*}{ Best ID } & \multicolumn{4}{|c|}{ FO (\%) } & \multicolumn{4}{|c|}{ RRA (\%) } \\
\hline & & & & $\mathbf{L F}$ & PH & $\begin{array}{l}\text { ZOO } \\
\text {.fish }\end{array}$ & $\begin{array}{l}\text { ZOO. } \\
\text { nofish }\end{array}$ & $\mathbf{L F}$ & PH & $\begin{array}{c}\text { ZOO. } \\
\text { fish }\end{array}$ & $\begin{array}{l}\text { ZOO. } \\
\text { nofish }\end{array}$ \\
\hline Annelida & Polychaeta & Phyllodocida & $\begin{array}{l}\text { Hypereteon } \\
\text { e } \\
\text { heteropoda } \\
\text { Neosabellar } \\
\text { ia } \\
\text { cementariu }\end{array}$ & NA & NA & NA & 15.4 & NA & NA & NA & 0.111 \\
\hline Annelida & Polychaeta & Sabellida & $\mathrm{m}$ & & & & & NA & NA & NA & 0.000 \\
\hline Annelida & Polychaeta & Sabellida & $\begin{array}{l}\text { Sabellariida } \\
\text { e sp. }\end{array}$ & NA & NA & 10.0 & 3.9 & NA & NA & 0.001 & 0.002 \\
\hline Annelida & Polychaeta & Spionida & $\begin{array}{l}\text { Marenzeller } \\
\text { ia neglecta }\end{array}$ & NA & NA & 70.0 & 53.9 & NA & NA & 0.225 & 0.026 \\
\hline Annelida & Polychaeta & Spionida & $\begin{array}{l}\text { Polydora } \\
\text { cornuta }\end{array}$ & NA & NA & 10.0 & 19.2 & NA & NA & 0.007 & 0.115 \\
\hline Annelida & Polychaeta & Spionida & $\begin{array}{l}\text { Streblospio } \\
\text { benedicti }\end{array}$ & NA & NA & 20.0 & 26.9 & NA & NA & 0.002 & 0.023 \\
\hline Annelida & Polychaeta & Xenopneusta & $\begin{array}{l}\text { Urechis } \\
\text { caupo }\end{array}$ & NA & NA & 10.0 & NA & NA & NA & 0.001 & NA \\
\hline $\begin{array}{l}\text { Apicomplex } \\
\text { a }\end{array}$ & Conoidasida & $\begin{array}{l}\text { Eucoccidiorid } \\
\text { a }\end{array}$ & $\begin{array}{l}\text { Eimeria } \\
\text { cahirinensis }\end{array}$ & NA & NA & NA & 3.9 & NA & NA & NA & 0.000 \\
\hline Arthropoda & $\begin{array}{l}\text { Branchiopod } \\
\text { a }\end{array}$ & Diplostraca & $\begin{array}{l}\text { Alona } \\
\text { setulosa }\end{array}$ & NA & NA & NA & 50.0 & NA & NA & NA & 0.082 \\
\hline Arthropoda & $\begin{array}{l}\text { Branchiopod } \\
\text { a }\end{array}$ & Diplostraca & Alona sp. & NA & NA & NA & 23.1 & NA & NA & NA & 0.027 \\
\hline Arthropoda & $\begin{array}{l}\text { Branchiopod } \\
\text { a }\end{array}$ & Diplostraca & $\begin{array}{l}\text { Bosmina } \\
\text { fatalis }\end{array}$ & NA & NA & 10.0 & 3.9 & NA & NA & 0.028 & 0.006 \\
\hline Arthropoda & $\begin{array}{l}\text { Branchiopod } \\
\text { a }\end{array}$ & Diplostraca & $\begin{array}{l}\text { Bosmina } \\
\text { liederi }\end{array}$ & NA & NA & 50.0 & 88.5 & NA & NA & 0.841 & 1.045 \\
\hline Arthropoda & $\begin{array}{l}\text { Branchiopod } \\
\text { a }\end{array}$ & Diplostraca & $\begin{array}{l}\text { Bosmina } \\
\text { longirostris }\end{array}$ & NA & NA & 80.0 & 84.6 & NA & NA & 1.406 & 3.118 \\
\hline Arthropoda & $\begin{array}{l}\text { Branchiopod } \\
\text { a }\end{array}$ & Diplostraca & Bosmina sp. & NA & NA & 10.0 & 61.5 & NA & NA & 0.027 & 0.303 \\
\hline Arthropoda & $\begin{array}{l}\text { Branchiopod } \\
\text { a }\end{array}$ & Diplostraca & $\begin{array}{l}\text { Bosminidae } \\
\text { sp. }\end{array}$ & NA & NA & 40.0 & 57.7 & NA & NA & 0.110 & 0.306 \\
\hline Arthropoda & $\begin{array}{l}\text { Branchiopod } \\
\text { a }\end{array}$ & Diplostraca & $\begin{array}{l}\text { Camptocerc } \\
\text { us sp. }\end{array}$ & NA & NA & NA & 7.7 & NA & NA & NA & 0.033 \\
\hline Arthropoda & $\begin{array}{l}\text { Branchiopod } \\
\text { a }\end{array}$ & Diplostraca & $\begin{array}{l}\text { Ceriodaphni } \\
\text { a dubia } \\
\text { Ceriodaphni }\end{array}$ & NA & NA & 10.0 & 7.7 & NA & NA & 0.006 & 0.028 \\
\hline Arthropoda & $\begin{array}{l}\text { Branchiopod } \\
\text { a }\end{array}$ & Diplostraca & $\begin{array}{l}\text { a } \\
\text { laticaudata }\end{array}$ & 2.1 & 3.2 & 50.0 & 69.2 & 0.276 & 0.956 & 0.306 & 1.075 \\
\hline Arthropoda & $\begin{array}{l}\text { Branchiopod } \\
\text { a }\end{array}$ & Diplostraca & $\begin{array}{l}\text { Ceriodaphni } \\
\text { a sp. }\end{array}$ & NA & 7.9 & 50.0 & 69.2 & NA & 1.313 & 0.509 & 0.933 \\
\hline Arthropoda & $\begin{array}{l}\text { Branchiopod } \\
\text { a }\end{array}$ & Diplostraca & $\begin{array}{l}\text { Chydorus } \\
\text { brevilabris }\end{array}$ & 1.0 & NA & 50.0 & 76.9 & 0.547 & NA & 0.144 & 1.537 \\
\hline Arthropoda & $\begin{array}{l}\text { Branchiopod } \\
\text { a }\end{array}$ & Diplostraca & $\begin{array}{l}\text { Chydorus } \\
\text { sp. }\end{array}$ & 1.0 & NA & NA & 50.0 & 0.066 & NA & NA & 0.200 \\
\hline Arthropoda & $\begin{array}{l}\text { Branchiopod } \\
\text { a }\end{array}$ & Diplostraca & $\begin{array}{l}\text { Daphnia } \\
\text { ambigua }\end{array}$ & NA & NA & 40.0 & 61.5 & NA & NA & 0.038 & 0.641 \\
\hline Arthropoda & $\begin{array}{l}\text { Branchiopod } \\
\text { a }\end{array}$ & Diplostraca & $\begin{array}{l}\text { Daphnia } \\
\text { galeata }\end{array}$ & NA & NA & NA & 3.9 & NA & NA & NA & 0.000 \\
\hline
\end{tabular}




\begin{tabular}{|c|c|c|c|c|c|c|c|c|c|c|c|}
\hline \multirow[b]{2}{*}{ Phylum } & \multirow[b]{2}{*}{ Class } & \multirow[b]{2}{*}{ Order } & \multirow[b]{2}{*}{ Best ID } & \multicolumn{4}{|c|}{ FO (\%) } & \multicolumn{4}{|c|}{ RRA (\%) } \\
\hline & & & & LF & PH & $\begin{array}{l}\text { ZOO } \\
\text {.fish }\end{array}$ & $\begin{array}{l}\text { ZOO. } \\
\text { nofish }\end{array}$ & $\mathbf{L F}$ & PH & $\begin{array}{c}\text { ZOO. } \\
\text { fish }\end{array}$ & $\begin{array}{l}\text { ZOO. } \\
\text { nofish }\end{array}$ \\
\hline Arthropoda & $\begin{array}{l}\text { Branchiopod } \\
\text { a }\end{array}$ & Diplostraca & $\begin{array}{l}\text { Daphnia } \\
\text { laevis }\end{array}$ & NA & NA & 10.0 & 15.4 & NA & NA & 0.074 & 0.051 \\
\hline Arthropoda & $\begin{array}{l}\text { Branchiopod } \\
\text { a }\end{array}$ & Diplostraca & $\begin{array}{l}\text { Daphnia } \\
\text { magna }\end{array}$ & 1.0 & NA & 10.0 & 19.2 & 0.019 & NA & 0.061 & 0.084 \\
\hline Arthropoda & $\begin{array}{l}\text { Branchiopod } \\
\text { a }\end{array}$ & Diplostraca & $\begin{array}{l}\text { Daphnia } \\
\text { mendotae }\end{array}$ & NA & NA & 10.0 & 7.7 & NA & NA & 0.020 & 0.037 \\
\hline Arthropoda & $\begin{array}{l}\text { Branchiopod } \\
\text { a }\end{array}$ & Diplostraca & $\begin{array}{l}\text { Daphnia } \\
\text { parvula }\end{array}$ & NA & NA & NA & 3.9 & NA & NA & NA & 0.000 \\
\hline Arthropoda & $\begin{array}{l}\text { Branchiopod } \\
\text { a }\end{array}$ & Diplostraca & $\begin{array}{l}\text { Daphnia } \\
\text { pulex }\end{array}$ & NA & NA & 10.0 & 15.4 & NA & NA & 0.002 & 0.002 \\
\hline Arthropoda & $\begin{array}{l}\text { Branchiopod } \\
\text { a }\end{array}$ & Diplostraca & Daphnia sp. & 1.0 & 7.9 & 80.0 & 65.4 & 0.266 & 2.062 & 1.007 & 0.540 \\
\hline Arthropoda & $\begin{array}{l}\text { Branchiopod } \\
\text { a }\end{array}$ & Diplostraca & $\begin{array}{l}\text { Daphniidae } \\
\text { sp. }\end{array}$ & NA & NA & 30.0 & 50.0 & NA & NA & 0.284 & 0.145 \\
\hline Arthropoda & $\begin{array}{l}\text { Branchiopod } \\
\text { a }\end{array}$ & Diplostraca & $\begin{array}{l}\text { Diaphanoso } \\
\text { ma heberti }\end{array}$ & NA & NA & NA & 3.9 & NA & NA & NA & 0.013 \\
\hline Arthropoda & $\begin{array}{l}\text { Branchiopod } \\
\text { a }\end{array}$ & Diplostraca & $\begin{array}{l}\text { Diaphanoso } \\
\text { ma sp. }\end{array}$ & NA & NA & NA & 7.7 & NA & NA & NA & 0.049 \\
\hline Arthropoda & $\begin{array}{l}\text { Branchiopod } \\
\text { a }\end{array}$ & Diplostraca & $\begin{array}{l}\text { Eubosmina } \\
\text { huaronensis }\end{array}$ & NA & NA & 30.0 & 30.8 & NA & NA & 0.093 & 0.148 \\
\hline Arthropoda & $\begin{array}{l}\text { Branchiopod } \\
\text { a }\end{array}$ & Diplostraca & $\begin{array}{l}\text { Holopedium } \\
\text { sp. }\end{array}$ & NA & NA & 10.0 & 3.9 & NA & NA & 0.006 & 0.004 \\
\hline Arthropoda & $\begin{array}{l}\text { Branchiopod } \\
\text { a }\end{array}$ & Diplostraca & $\begin{array}{l}\text { Kurzia } \\
\text { media }\end{array}$ & NA & NA & NA & 11.5 & NA & NA & NA & 0.005 \\
\hline Arthropoda & $\begin{array}{l}\text { Branchiopod } \\
\text { a }\end{array}$ & Diplostraca & $\begin{array}{l}\text { Kurzia sp. } \\
\text { Leydigia }\end{array}$ & NA & NA & NA & 3.9 & NA & NA & NA & 0.010 \\
\hline Arthropoda & $\begin{array}{l}\text { Branchiopod } \\
\text { a }\end{array}$ & Diplostraca & $\begin{array}{l}\text { acanthocerc } \\
\text { oides }\end{array}$ & NA & NA & NA & 3.9 & NA & NA & NA & 0.010 \\
\hline Arthropoda & $\begin{array}{l}\text { Branchiopod } \\
\text { a }\end{array}$ & Diplostraca & $\begin{array}{l}\text { Leydigia } \\
\text { lousi }\end{array}$ & NA & NA & NA & 11.5 & NA & NA & NA & 0.016 \\
\hline Arthropoda & $\begin{array}{l}\text { Branchiopod } \\
\text { a }\end{array}$ & Diplostraca & $\begin{array}{l}\text { Macrothrix } \\
\text { sp. }\end{array}$ & NA & NA & NA & 11.5 & NA & NA & NA & 0.005 \\
\hline Arthropoda & $\begin{array}{l}\text { Branchiopod } \\
\text { a }\end{array}$ & Diplostraca & $\begin{array}{l}\text { Moina } \\
\text { macrocopa }\end{array}$ & NA & NA & 10.0 & 11.5 & NA & NA & 0.009 & 0.011 \\
\hline Arthropoda & $\begin{array}{l}\text { Branchiopod } \\
\text { a }\end{array}$ & Diplostraca & $\begin{array}{l}\text { Ovalona } \\
\text { glabra }\end{array}$ & NA & NA & NA & 7.7 & NA & NA & NA & 0.017 \\
\hline Arthropoda & $\begin{array}{l}\text { Branchiopod } \\
\text { a }\end{array}$ & Diplostraca & $\begin{array}{l}\text { Pleuroxus } \\
\text { sp. }\end{array}$ & NA & NA & 10.0 & 3.9 & NA & NA & 0.002 & 0.000 \\
\hline Arthropoda & $\begin{array}{l}\text { Branchiopod } \\
\text { a }\end{array}$ & Diplostraca & $\begin{array}{l}\text { Pleuroxus } \\
\text { varidentatus }\end{array}$ & NA & NA & NA & 3.9 & NA & NA & NA & 0.000 \\
\hline Arthropoda & $\begin{array}{l}\text { Branchiopod } \\
\text { a }\end{array}$ & Diplostraca & $\begin{array}{l}\text { Pseudochyd } \\
\text { orus } \\
\text { globosus }\end{array}$ & NA & NA & NA & 11.5 & NA & NA & NA & 0.002 \\
\hline Arthropoda & $\begin{array}{l}\text { Branchiopod } \\
\text { a }\end{array}$ & Diplostraca & $\begin{array}{l}\text { Sida } \\
\text { crystallina } \\
\text { Simocephal }\end{array}$ & NA & NA & NA & 3.9 & NA & NA & NA & 0.000 \\
\hline Arthropoda & $\begin{array}{l}\text { Branchiopod } \\
\text { a }\end{array}$ & Diplostraca & $\begin{array}{l}\text { us } \\
\text { exspinosus }\end{array}$ & NA & NA & 20.0 & 50.0 & NA & NA & 0.040 & 0.493 \\
\hline Arthropoda & $\begin{array}{l}\text { Branchiopod } \\
\text { a }\end{array}$ & Diplostraca & $\begin{array}{l}\text { Simocephal } \\
\text { us punctatus }\end{array}$ & NA & NA & 10.0 & 11.5 & NA & NA & 0.000 & 0.061 \\
\hline
\end{tabular}




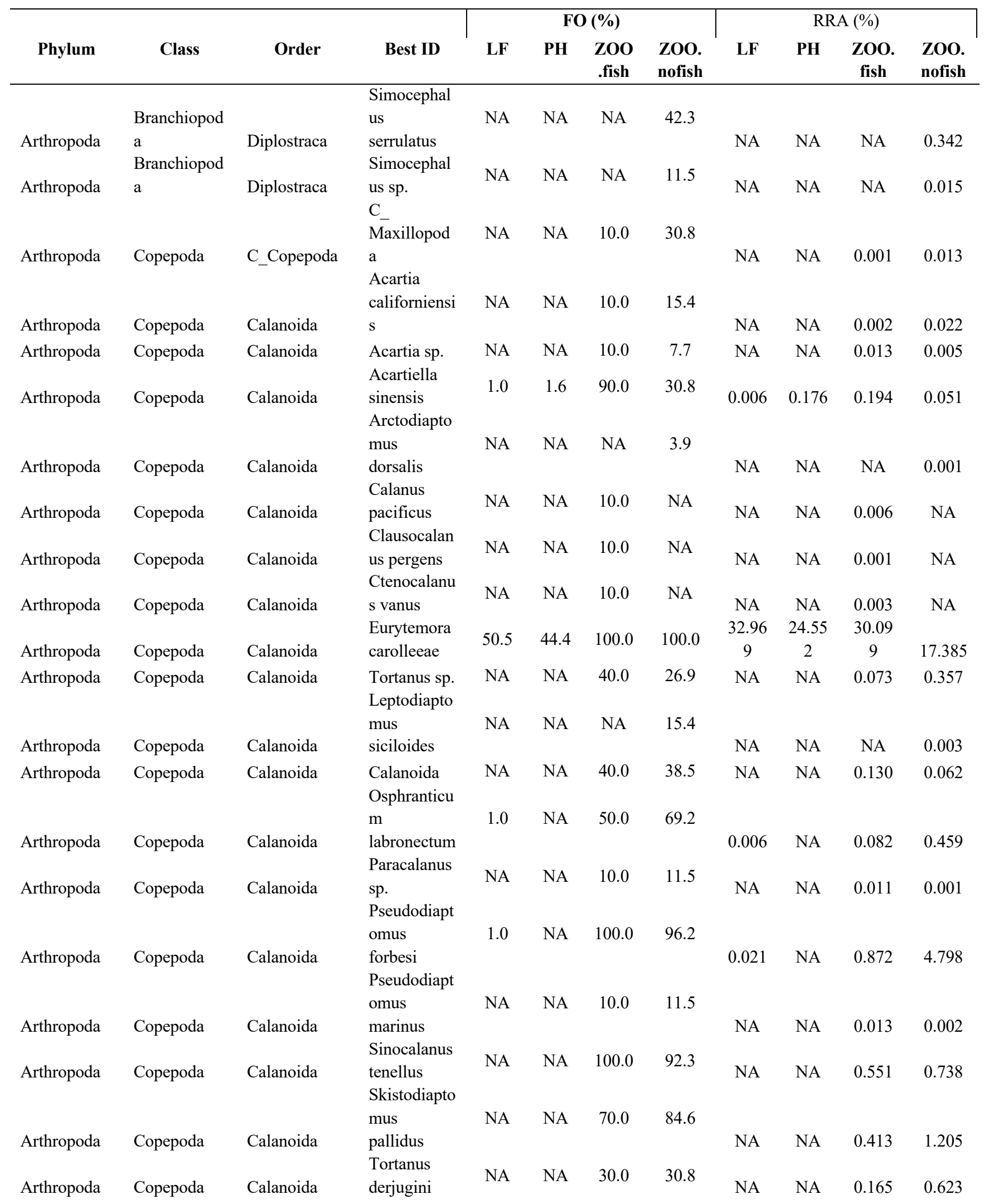




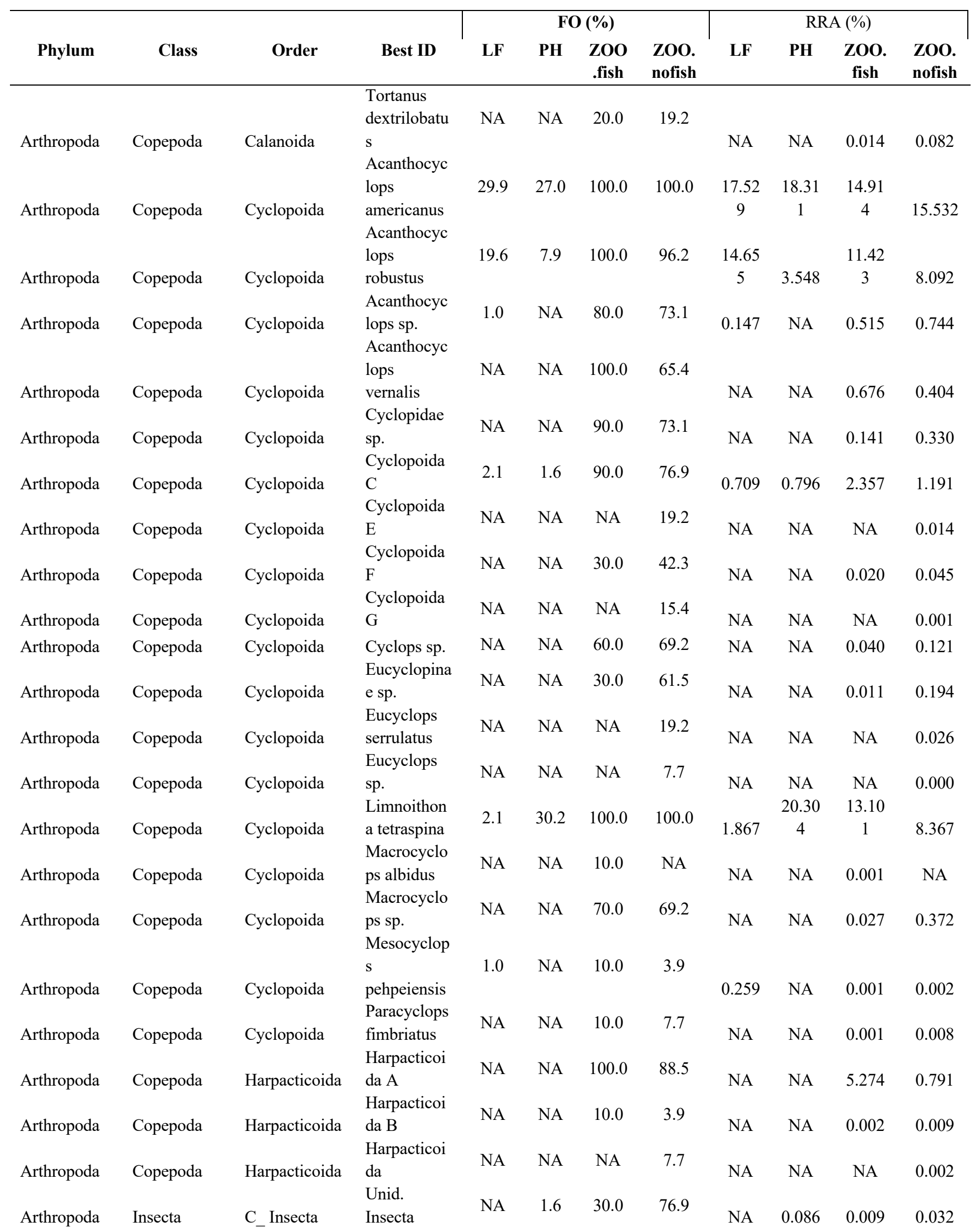




\begin{tabular}{|c|c|c|c|c|c|c|c|c|c|c|c|}
\hline \multirow[b]{2}{*}{ Phylum } & \multirow[b]{2}{*}{ Class } & \multirow[b]{2}{*}{ Order } & \multirow[b]{2}{*}{ Best ID } & \multicolumn{4}{|c|}{ FO (\%) } & \multicolumn{4}{|c|}{ RRA (\%) } \\
\hline & & & & $\mathbf{L F}$ & PH & $\begin{array}{c}\text { ZOO } \\
\text {.fish } \\
\end{array}$ & $\begin{array}{l}\text { ZOO. } \\
\text { nofish }\end{array}$ & $\mathbf{L F}$ & $\mathbf{P H}$ & $\begin{array}{c}\text { ZOO. } \\
\text { fish }\end{array}$ & $\begin{array}{l}\text { ZOO. } \\
\text { nofish }\end{array}$ \\
\hline Arthropoda & Insecta & Coleoptera & $\begin{array}{l}\text { Prionus } \\
\text { insularis }\end{array}$ & NA & NA & NA & 11.5 & NA & NA & NA & 0.001 \\
\hline Arthropoda & Insecta & Diptera & $\begin{array}{l}\text { Chironomid } \\
\text { ae sp. }\end{array}$ & NA & NA & NA & 3.9 & NA & NA & NA & 0.003 \\
\hline Arthropoda & Insecta & Diptera & $\begin{array}{l}\text { Chironomin } \\
\text { ae sp. }\end{array}$ & NA & NA & NA & 3.9 & NA & NA & NA & 0.015 \\
\hline Arthropoda & Insecta & Diptera & $\begin{array}{l}\text { Chironomus } \\
\text { maturus }\end{array}$ & NA & NA & NA & 11.5 & NA & NA & NA & 0.004 \\
\hline Arthropoda & Insecta & Diptera & $\begin{array}{l}\text { Corynoneur } \\
\text { a arctica }\end{array}$ & NA & NA & NA & 7.7 & NA & NA & NA & 0.007 \\
\hline Arthropoda & Insecta & Diptera & $\begin{array}{l}\text { Cosmosciar } \\
\text { a sp. }\end{array}$ & NA & NA & 10.0 & NA & NA & NA & 0.005 & NA \\
\hline Arthropoda & Insecta & Diptera & $\begin{array}{l}\text { Cricotopus } \\
\text { sp. }\end{array}$ & NA & NA & NA & 7.7 & NA & NA & NA & 0.006 \\
\hline Arthropoda & Insecta & Diptera & Diptera & NA & NA & 10.0 & 3.9 & NA & NA & 0.001 & 0.001 \\
\hline Arthropoda & Insecta & Diptera & $\begin{array}{l}\text { Orthocladiu } \\
\text { s sp. }\end{array}$ & NA & NA & NA & 3.9 & NA & NA & NA & 0.000 \\
\hline Arthropoda & Insecta & Diptera & $\begin{array}{l}\text { Paratanytars } \\
\text { us grimmii }\end{array}$ & NA & NA & 40.0 & 42.3 & NA & NA & 0.018 & 0.092 \\
\hline Arthropoda & Insecta & Diptera & $\begin{array}{l}\text { Procladius } \\
\text { sp. }\end{array}$ & NA & NA & NA & 3.9 & NA & NA & NA & 0.000 \\
\hline Arthropoda & Insecta & Hemiptera & $\begin{array}{l}\text { Colobopyga } \\
\text { pritchardiae }\end{array}$ & NA & NA & NA & 7.7 & NA & NA & NA & 0.000 \\
\hline Arthropoda & Insecta & Hemiptera & Hemiptera & NA & NA & NA & 19.2 & NA & NA & NA & 0.001 \\
\hline Arthropoda & Insecta & Lepidoptera & $\begin{array}{l}\text { Argyrotaeni } \\
\text { a citrana }\end{array}$ & NA & NA & NA & 3.9 & NA & NA & NA & 0.001 \\
\hline Arthropoda & Insecta & Psocoptera & $\begin{array}{l}\text { Liposcelis } \\
\text { rufa }\end{array}$ & 2.1 & NA & NA & NA & 1.125 & NA & NA & NA \\
\hline Arthropoda & Insecta & Zygentoma & $\begin{array}{l}\text { Thermobia } \\
\text { domestica }\end{array}$ & NA & NA & NA & 3.9 & NA & NA & NA & 0.000 \\
\hline Arthropoda & $\begin{array}{l}\text { Malacostrac } \\
\mathrm{a}\end{array}$ & Amphipoda & $\begin{array}{l}\text { Corophiidae } \\
\text { sp. }\end{array}$ & NA & NA & NA & 7.7 & NA & NA & NA & 0.001 \\
\hline Arthropoda & $\begin{array}{l}\text { Malacostrac } \\
\text { a }\end{array}$ & Amphipoda & $\begin{array}{l}\text { Gammarus } \\
\text { daiberi }\end{array}$ & NA & NA & 30.0 & 34.6 & NA & NA & 0.021 & 0.276 \\
\hline Arthropoda & $\begin{array}{l}\text { Malacostrac } \\
\text { a }\end{array}$ & Amphipoda & $\begin{array}{l}\text { Grandidiere } \\
\text { lla japonica } \\
\text { Hemigrapsu }\end{array}$ & NA & NA & NA & 15.4 & NA & NA & NA & 0.003 \\
\hline Arthropoda & $\begin{array}{l}\text { Malacostrac } \\
\text { a }\end{array}$ & Decapoda & $\begin{array}{l}\mathrm{S} \\
\text { oregonensis }\end{array}$ & NA & NA & 10.0 & NA & NA & NA & 0.000 & NA \\
\hline Arthropoda & $\begin{array}{l}\text { Malacostrac } \\
\text { a }\end{array}$ & Decapoda & $\begin{array}{l}\text { Palaemon } \\
\text { modestus }\end{array}$ & NA & 1.6 & NA & NA & NA & 0.285 & NA & NA \\
\hline Arthropoda & $\begin{array}{l}\text { Malacostrac } \\
\text { a }\end{array}$ & Decapoda & $\begin{array}{l}\text { Upogebia } \\
\text { major } \\
\text { Hyperacant }\end{array}$ & NA & NA & 10.0 & NA & NA & NA & 0.069 & NA \\
\hline Arthropoda & $\begin{array}{l}\text { Malacostrac } \\
\text { a }\end{array}$ & Mysida & $\begin{array}{l}\text { homysis } \\
\text { longirostris }\end{array}$ & NA & NA & 50.0 & 38.5 & NA & NA & 0.597 & 0.069 \\
\hline Arthropoda & $\begin{array}{l}\text { Malacostrac } \\
\mathrm{a}\end{array}$ & Mysida & Mysidae sp. & NA & NA & NA & 3.9 & NA & NA & NA & 0.000 \\
\hline Arthropoda & $\begin{array}{l}\text { Malacostrac } \\
\text { a }\end{array}$ & Mysida & $\begin{array}{l}\text { Neomysis } \\
\text { japonica }\end{array}$ & 4.1 & 6.4 & 30.0 & 15.4 & 0.172 & 0.789 & 0.088 & 0.002 \\
\hline
\end{tabular}




\begin{tabular}{|c|c|c|c|c|c|c|c|c|c|c|c|}
\hline \multirow[b]{2}{*}{ Phylum } & \multirow[b]{2}{*}{ Class } & \multirow[b]{2}{*}{ Order } & \multirow[b]{2}{*}{ Best ID } & \multicolumn{4}{|c|}{ FO (\%) } & \multicolumn{4}{|c|}{ RRA (\%) } \\
\hline & & & & $\mathbf{L F}$ & PH & $\begin{array}{c}\text { ZOO } \\
\text {.fish }\end{array}$ & $\begin{array}{l}\text { ZOO. } \\
\text { nofish }\end{array}$ & $\mathbf{L F}$ & PH & $\begin{array}{c}\text { ZOO. } \\
\text { fish }\end{array}$ & $\begin{array}{l}\text { ZOO. } \\
\text { nofish }\end{array}$ \\
\hline Arthropoda & Ostracoda & Podocopida & Cypria sp. & NA & NA & NA & 7.7 & NA & NA & NA & 0.012 \\
\hline Arthropoda & Ostracoda & Podocopida & $\begin{array}{l}\text { Cypridopsis } \\
\text { sp. }\end{array}$ & NA & NA & NA & 30.8 & NA & NA & NA & 0.034 \\
\hline Arthropoda & Ostracoda & Podocopida & $\begin{array}{l}\text { Cypridopsis } \\
\text { vidua }\end{array}$ & NA & NA & 10.0 & 30.8 & NA & NA & 0.002 & 0.020 \\
\hline Arthropoda & Ostracoda & Podocopida & $\begin{array}{l}\text { Eucypris } \\
\text { pigra }\end{array}$ & NA & NA & NA & 3.9 & NA & NA & NA & 0.005 \\
\hline Arthropoda & Ostracoda & Podocopida & $\begin{array}{l}\text { Eucypris } \\
\text { virens }\end{array}$ & NA & NA & 10.0 & 26.9 & NA & NA & 0.002 & 0.101 \\
\hline Arthropoda & Ostracoda & Podocopida & Cyprididae & NA & NA & NA & 15.4 & NA & NA & NA & 0.001 \\
\hline Arthropoda & Ostracoda & Podocopida & Podocopida & NA & NA & 30.0 & 42.3 & NA & NA & 0.004 & 0.062 \\
\hline Arthropoda & $\begin{array}{l}\mathrm{P}_{-} \\
\text {Arthropoda }\end{array}$ & $\begin{array}{l}\mathrm{P}_{-} \\
\text {Arthropoda }\end{array}$ & $\begin{array}{l}\text { Unid. } \\
\text { Arthropoda } \\
\text { Amphibalan }\end{array}$ & 4.1 & 7.9 & 100.0 & 100.0 & 0.178 & 0.792 & 1.273 & 1.806 \\
\hline Arthropoda & Thecostraca & Sessilia & $\begin{array}{l}\text { us } \\
\text { amphitrite } \\
\text { Amphibalan }\end{array}$ & NA & NA & NA & 3.9 & NA & NA & NA & 0.003 \\
\hline Arthropoda & Thecostraca & Sessilia & $\begin{array}{l}\text { us } \\
\text { improvisus }\end{array}$ & NA & NA & 20.0 & 34.6 & NA & NA & 0.128 & 0.242 \\
\hline Arthropoda & Thecostraca & Sessilia & $\begin{array}{l}\text { Balanidae } \\
\text { sp. }\end{array}$ & NA & NA & NA & 3.9 & NA & NA & NA & 0.001 \\
\hline Arthropoda & Thecostraca & Sessilia & $\begin{array}{l}\text { Balanus } \\
\text { crenatus }\end{array}$ & NA & 1.6 & NA & NA & NA & 0.423 & NA & NA \\
\hline Arthropoda & Thecostraca & Sessilia & $\begin{array}{l}\text { Balanus } \\
\text { glandula }\end{array}$ & NA & NA & NA & 11.5 & NA & NA & NA & 0.002 \\
\hline Arthropoda & Thecostraca & Sessilia & Balanus sp. & NA & NA & 10.0 & 3.9 & NA & NA & 0.001 & 0.000 \\
\hline Arthropoda & Thecostraca & Sessilia & $\begin{array}{l}\text { Chthamalid } \\
\text { ae sp. } \\
\text { Conopeum }\end{array}$ & NA & NA & NA & 3.9 & NA & NA & NA & 0.001 \\
\hline Bryozoa & $\begin{array}{l}\text { Gymnolaem } \\
\text { ata }\end{array}$ & $\begin{array}{l}\text { Cheilostomati } \\
\text { da }\end{array}$ & $\begin{array}{l}\text { chesapeake } \\
\text { nsis }\end{array}$ & NA & NA & 10.0 & NA & NA & NA & 0.107 & NA \\
\hline Bryozoa & $\begin{array}{l}\text { Gymnolaem } \\
\text { ata }\end{array}$ & $\begin{array}{l}\text { Cheilostomati } \\
\text { da }\end{array}$ & $\begin{array}{l}\text { Conopeum } \\
\text { tenuissimu } \\
\mathrm{m}\end{array}$ & NA & NA & NA & 15.4 & NA & NA & NA & 0.059 \\
\hline Bryozoa & $\begin{array}{l}\text { Gymnolaem } \\
\text { ata }\end{array}$ & $\begin{array}{l}\text { Cheilostomati } \\
\text { da }\end{array}$ & Electra sp. & NA & NA & NA & 3.9 & NA & NA & NA & 0.000 \\
\hline Chordata & Actinopteri & $\begin{array}{l}\mathrm{C}_{-} \\
\text {Actinopteri }\end{array}$ & Actinopteri & NA & NA & NA & 3.9 & NA & NA & NA & 0.001 \\
\hline Chordata & Actinopteri & Clupeiformes & $\begin{array}{l}\text { Clupea } \\
\text { pallasii } \\
\text { Pogonichth }\end{array}$ & 18.6 & NA & 40.0 & 3.9 & 8.401 & NA & 0.360 & 0.000 \\
\hline & & Cypriniforme & $\begin{array}{l}\text { ys } \\
\text { macrolepido }\end{array}$ & NA & NA & NA & 3.9 & & & & \\
\hline Chordata & Actinopteri & $\mathrm{s}$ & tus & & & & & NA & NA & NA & 0.000 \\
\hline Chordata & Actinopteri & $\begin{array}{l}\text { Cyprinodontif } \\
\text { ormes }\end{array}$ & $\begin{array}{l}\text { Gambusia } \\
\text { affinis } \\
\text { Acanthogob }\end{array}$ & NA & NA & NA & 3.9 & NA & NA & NA & 0.000 \\
\hline Chordata & Actinopteri & Gobiiformes & $\begin{array}{l}\text { ius } \\
\text { flavimanus }\end{array}$ & 1.0 & NA & NA & NA & 0.005 & NA & NA & NA \\
\hline
\end{tabular}




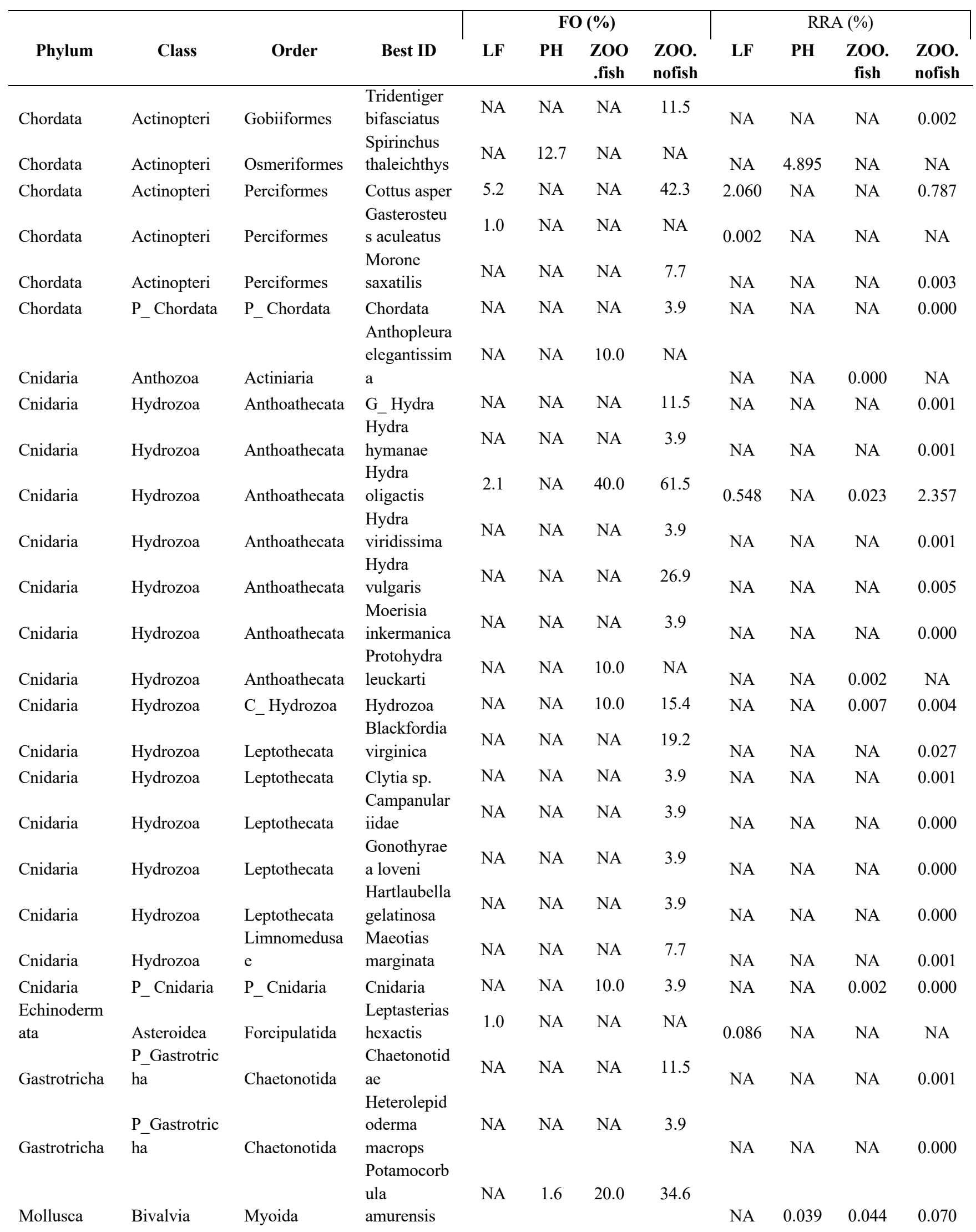




\begin{tabular}{|c|c|c|c|c|c|c|c|c|c|c|c|}
\hline \multirow[b]{2}{*}{ Phylum } & \multirow[b]{2}{*}{ Class } & \multirow[b]{2}{*}{ Order } & \multirow[b]{2}{*}{ Best ID } & \multicolumn{4}{|c|}{ FO (\%) } & \multicolumn{4}{|c|}{ RRA (\%) } \\
\hline & & & & $\mathbf{L F}$ & PH & $\begin{array}{l}\text { ZOO } \\
\text {.fish }\end{array}$ & $\begin{array}{l}\text { ZOO. } \\
\text { nofish }\end{array}$ & $\mathbf{L F}$ & PH & $\begin{array}{l}\text { ZOO. } \\
\text { fish }\end{array}$ & $\begin{array}{l}\text { ZOO. } \\
\text { nofish }\end{array}$ \\
\hline & & & $\begin{array}{l}\text { Adula } \\
\text { californiensi }\end{array}$ & NA & NA & 10.0 & NA & & & & \\
\hline Mollusca & Bivalvia & Mytiloida & $\mathrm{s}$ & & & & & NA & NA & 0.003 & NA \\
\hline Mollusca & Bivalvia & Mytiloida & $\begin{array}{l}\text { Geukensia } \\
\text { demissa }\end{array}$ & NA & NA & NA & 3.9 & NA & NA & NA & 0.001 \\
\hline Mollusca & Bivalvia & Veneroida & $\begin{array}{l}\text { Limecola } \\
\text { balthica }\end{array}$ & NA & NA & 10.0 & 11.5 & NA & NA & 0.014 & 0.002 \\
\hline Mollusca & Bivalvia & Veneroida & $\begin{array}{l}\text { Macoma } \\
\text { petalum }\end{array}$ & NA & NA & 30.0 & 19.2 & NA & NA & 0.103 & 0.049 \\
\hline Mollusca & Bivalvia & Veneroida & $\begin{array}{l}\text { Ruditapes } \\
\text { philippinaru } \\
\text { m }\end{array}$ & NA & NA & NA & 15.4 & NA & NA & NA & 0.022 \\
\hline Mollusca & Gastropoda & $\begin{array}{l}\mathrm{C}_{-} \\
\text {Gastropoda }\end{array}$ & $\begin{array}{l}\text { Gastropoda } \\
\text { Potamopyrg }\end{array}$ & NA & NA & NA & 3.9 & NA & NA & NA & 0.000 \\
\hline Mollusca & Gastropoda & $\begin{array}{l}\text { Littorinimorp } \\
\text { ha }\end{array}$ & $\begin{array}{l}\text { us } \\
\text { antipodaru } \\
\text { m }\end{array}$ & NA & NA & NA & 3.9 & NA & NA & NA & 0.012 \\
\hline Mollusca & Gastropoda & $\begin{array}{l}\text { Littorinimorp } \\
\text { ha }\end{array}$ & $\begin{array}{l}\text { Spurwinkia } \\
\text { salsa }\end{array}$ & NA & NA & NA & 15.4 & NA & NA & NA & 0.001 \\
\hline Mollusca & Gastropoda & $\begin{array}{l}\text { Neogastropod } \\
\text { a }\end{array}$ & $\begin{array}{l}\text { Tritia } \\
\text { obsoleta }\end{array}$ & NA & NA & NA & 11.5 & NA & NA & NA & 0.040 \\
\hline Mollusca & Gastropoda & Sarcoglossa & $\begin{array}{l}\text { Alderia } \\
\text { modesta }\end{array}$ & NA & NA & NA & 15.4 & NA & NA & NA & 0.003 \\
\hline Nematoda & Enoplea & Dorylaimida & $\begin{array}{l}\text { Xiphinema } \\
\text { pachtaicum }\end{array}$ & NA & NA & 10.0 & NA & NA & NA & 0.002 & NA \\
\hline $\begin{array}{l}\text { non- } \\
\text { metazoans }\end{array}$ & $\begin{array}{l}\text { non- } \\
\text { metazoans }\end{array}$ & $\begin{array}{l}\text { non- } \\
\text { metazoans }\end{array}$ & $\begin{array}{l}\text { non- } \\
\text { metazoans }\end{array}$ & 5.2 & 3.2 & 100.0 & 100.0 & 1.121 & 0.005 & 2.041 & 5.216 \\
\hline $\begin{array}{l}\text { Platyhelmint } \\
\text { hes }\end{array}$ & Catenulida & C_Catenulida & $\begin{array}{l}\text { Stenostomu } \\
\text { m leucops }\end{array}$ & NA & NA & NA & 19.2 & NA & NA & NA & 0.006 \\
\hline Porifera & $\begin{array}{l}\text { Demospongi } \\
\text { ae }\end{array}$ & Spongillida & $\begin{array}{l}\text { Spongilla } \\
\text { lacustris }\end{array}$ & NA & NA & NA & 19.2 & NA & NA & NA & 0.002 \\
\hline Tardigrada & Eutardigrada & Parachela & $\begin{array}{l}\text { Thulinius } \\
\text { sp. }\end{array}$ & NA & NA & NA & 3.9 & NA & NA & NA & 0.000 \\
\hline Unknown & Unknown & Unknown & Unknown & 55.7 & 57.1 & 100.0 & 100.0 & $\begin{array}{c}16.95 \\
5\end{array}$ & $\begin{array}{c}20.66 \\
8\end{array}$ & 8.471 & 13.043 \\
\hline
\end{tabular}


1432 Supplementary Table 5. Name adjustments.

1433

\begin{tabular}{|c|c|c|c|c|}
\hline Previous description & Name in this paper & Blast hit & Accession & $\begin{array}{l}\text { Identity } \\
\%\end{array}$ \\
\hline Tortanus dextrilobatus & Tortanus dextrilobatus & Tortanus derjugini & HМ045418.1 & 97.1 \\
\hline Sinocalanus doerrii & Sinocalanus doerrii & Sinocalanus tenellus & KX620038.1 & 100 \\
\hline Eurytemora affinis* & $\begin{array}{l}\text { Eurytemora carolleeae } \\
\text { Mesocyclops }\end{array}$ & Eurytemora carolleeae & MG936494.1 & 98.7 \\
\hline $\begin{array}{l}\text { Mesocyclops sp. } \\
\text { Amphibalanus amphitrite, }\end{array}$ & pehpeiensis & Mesocyclops pehpeiensis & KJ020571.1 & 100 \\
\hline $\begin{array}{l}\text { Balanus crenatus, others } \\
\text { Neomysis japonica }\end{array}$ & Balanus crenatus & Balanus balanus & MG936454.1 & 99.7 \\
\hline Neomysis kadiakensis & Neomysis sp. & Neomysis japonica & KR006340.1 & 93.5 \\
\hline
\end{tabular}

1434 *Note: Eurytemora affinis previously described in San Francisco Estuary but more recent 1435 genetic work has described a new species/subspecies, E. carolleae, that is the most up to date 1436 description of the species is present (Alekseev and Souissi 2011). 
1438

1439

1440

1441

\section{Supplementary Figures}
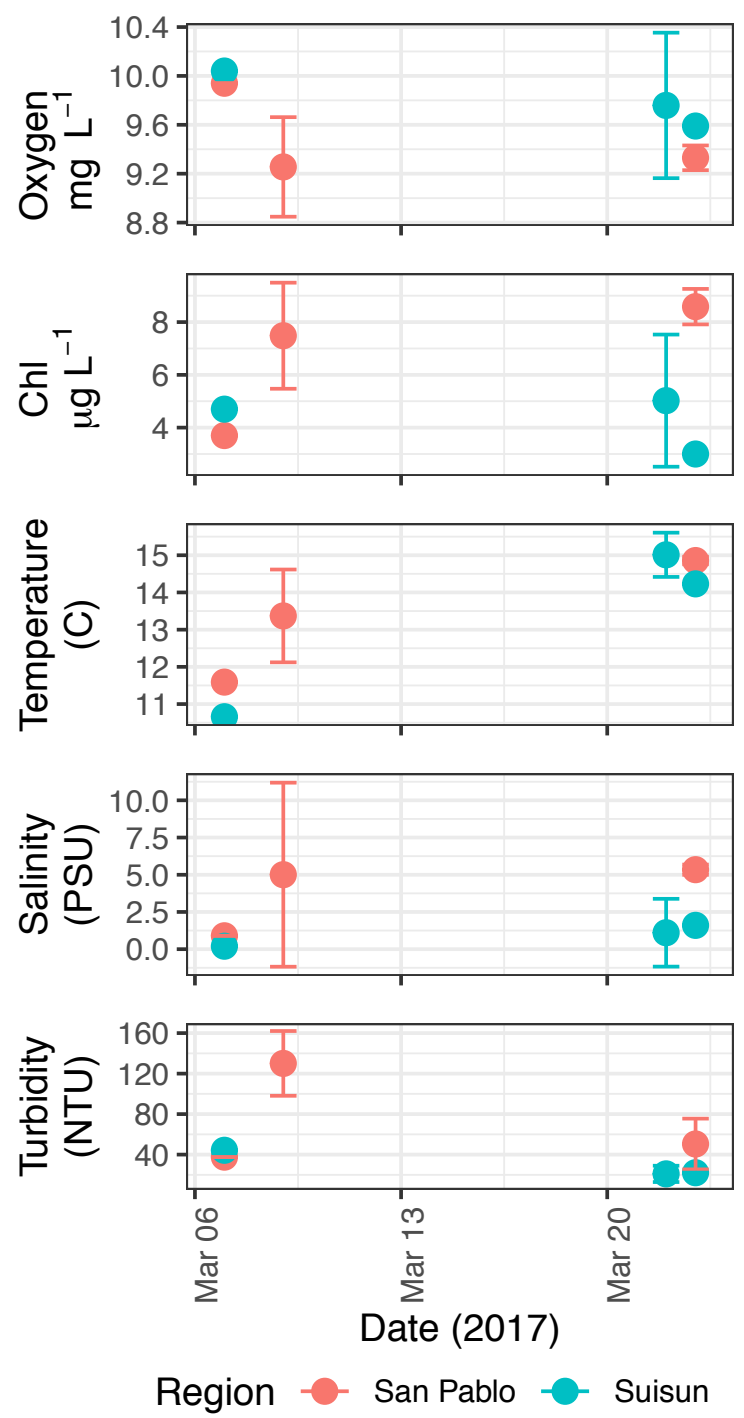

1442

1443 Supplementary Figure 1. Environmental data summary for San Pablo Bay and Suisun Bay on 1444 sampling dates during this study, showing the mean and standard deviation value of each daily 1445 measurement across sites where the target species of larval fish were sampled that day. 
A.

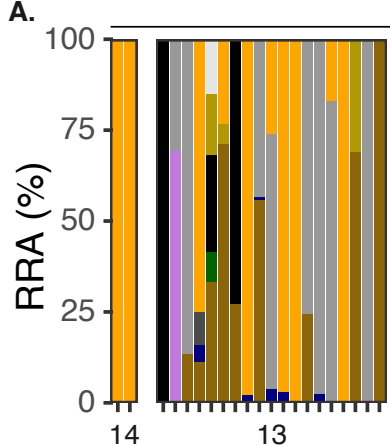

B.

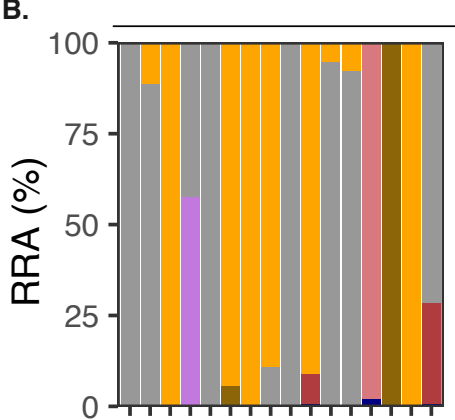

13
San Pablo

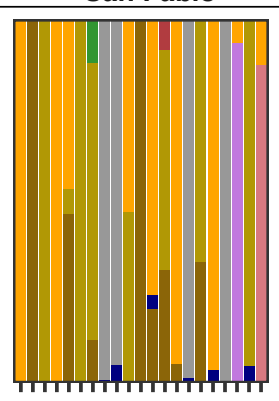

24
San Pablo

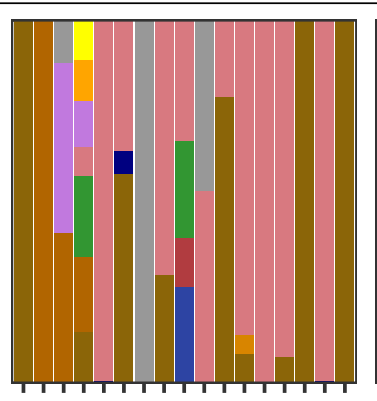

24

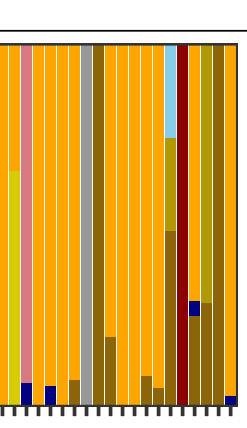

15
Tow \#

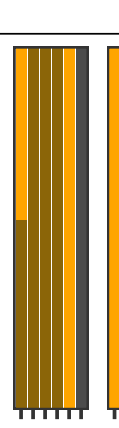

$16 \quad 26 \quad 21$

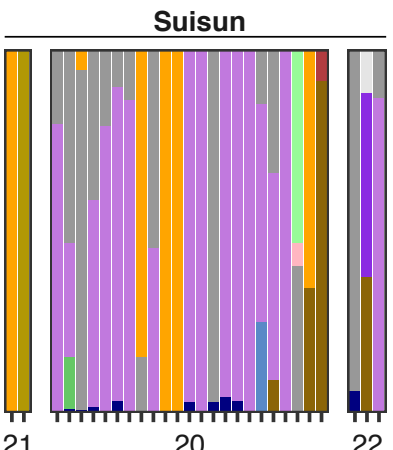

20

Suisun

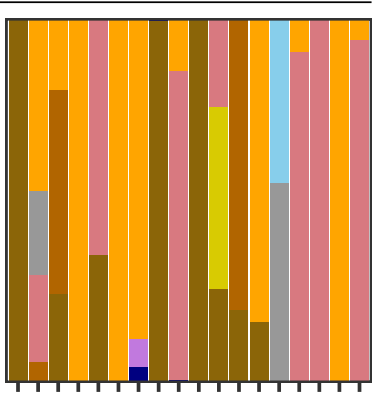

15

Tow \#

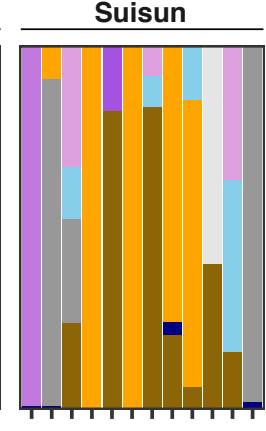

23

\begin{tabular}{|c|c|c|c|c|c|}
\hline $\begin{array}{l}\text { Best ID } \\
\text { Ceriodaphnia laticaudata } \\
\text { Ceriodaphnia sp. } \\
\text { Chydorus brevilabris } \\
\text { Chydorus sp. } \\
\text { Daphnia sp. } \\
\text { Acartiella sinensis } \\
\text { Eurytemora carolleeae } \\
\text { Acanthocyclops americanus } \\
\text { Acanthocyclops robustus } \\
\text { Acanthocyclops sp. } \\
\text { Limnoithona tetraspina } \\
\text { Mesocyclops pehpeiensis } \\
\text { Unid. Cyclopoida } \\
\text { Unid. Insecta }\end{array}$ & $\begin{array}{l}\text { Class } \\
\text { Diplostraca } \\
\text { Copepoda }\end{array}$ & Phylum & $\begin{array}{l}\text { Best ID } \\
\text { Liposcelis rufa } \\
\text { Palaemon modestus } \\
\text { Neomysis japonica } \\
\text { Unid. Arthropoda } \\
\text { Balanus crenatus } \\
\text { Clupea pallasii } \\
\text { Spirinchus thaleichthys } \\
\text { Cottus asper } \\
\text { Hydra oligactis } \\
\text { Leptasterias hexactis } \\
\text { non-metazoans } \\
\text { Other } \\
\text { Unknown }\end{array}$ & $\begin{array}{l}\text { Class } \\
\text { Insecta } \\
\text { Malacostraca } \\
\text { Thecostraca } \\
\text { Actinopteri } \\
\text { Hydrozoa } \\
\text { Asteroidea }\end{array}$ & $\begin{array}{l}\text { Chordata } \\
\text { Cnidaria } \\
\text { Echinodermata }\end{array}$ \\
\hline
\end{tabular}

1453 Supplementary Figure 2: Individual variation in relative read abundances (RRA \%) in fish guts 1454 for longfin smelt samples (A) and Pacific herring samples (B) across regions and tow number. 1455 "Other" group includes $<5 \%$ contribution to the sample. Unknowns are those identified with $<$ $145680 \%$ RDP bootstrap confidence. 


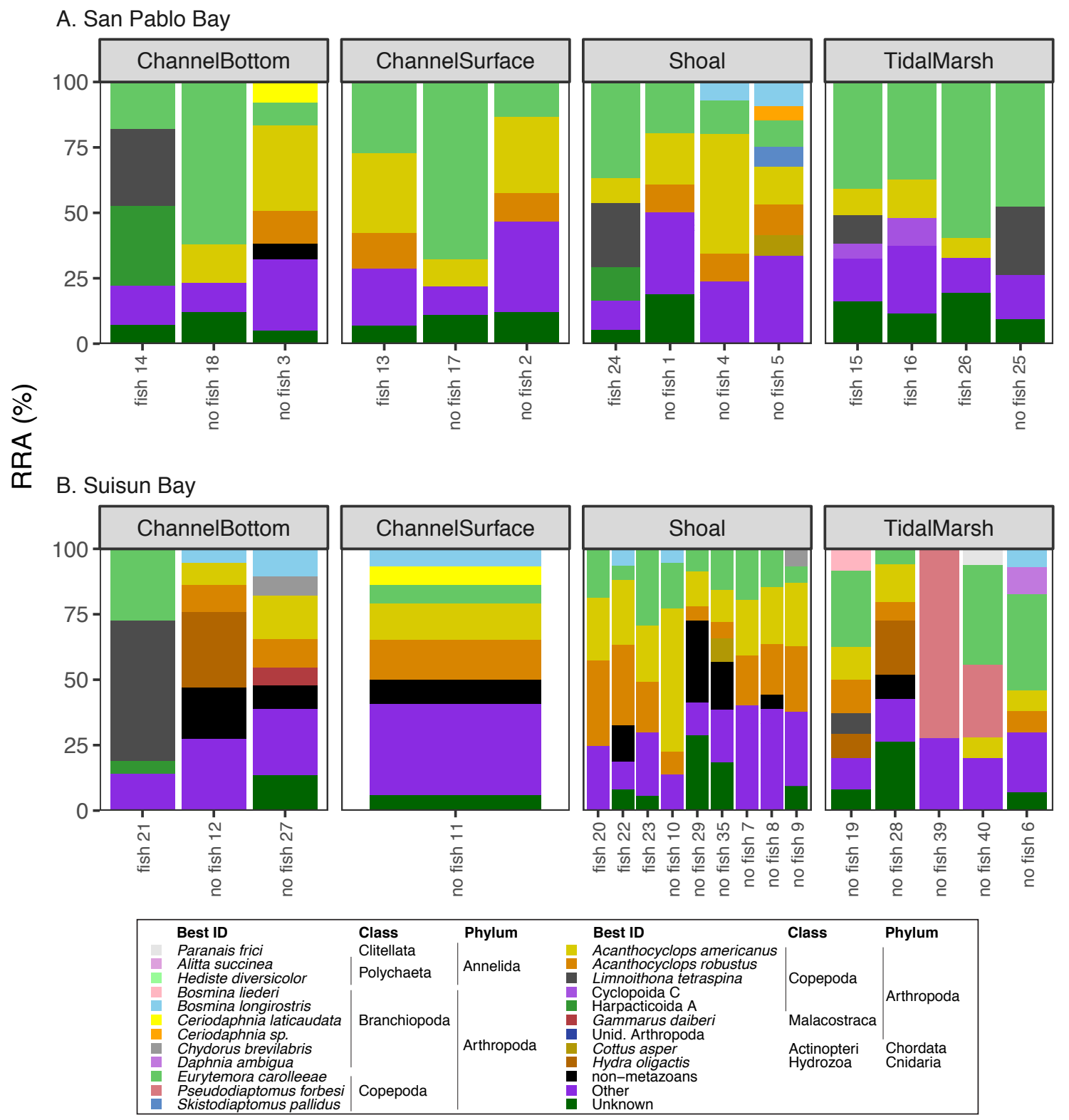

1463 Supplementary Figure 3 Individual variation in relative read abundances (RRA \%) in

1464 zooplankton samples by habitat. Other is < 5\% contribution. Tow number and whether the

1465 sample had longfin smelt concurrently collected and sequenced (fish) or not (no fish) are shown

1466 on the $x$-axis. 


\section{Sequence length distribution of all ASVs}

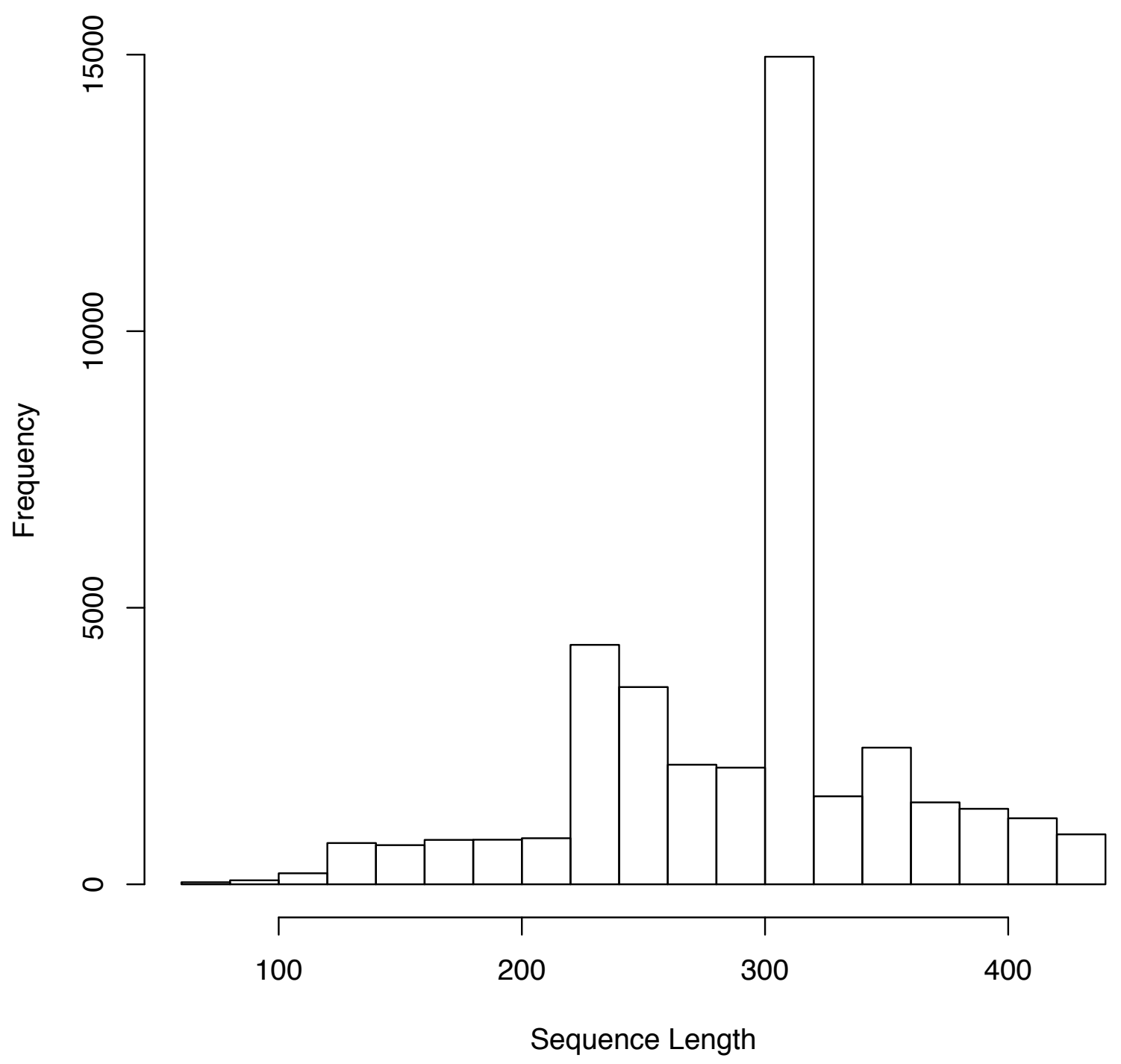

1469

1470 Supplementary Figure 4. Histogram of sequence lengths in DADA2-processed set of amplicon 1471 sequence variants (ASVS).

1472 